Ana Cristina Bragatto

\title{
A GESTÃ̃ DO CONHECIMENTO ATRAVÉS DO USO DA METODOLOGIA ENTERPRISE KNOWLEDGE DEVELOPMENT (EKD): PROPOSIÇÃO DE UM MÉTODO DE TRABALHO
}

Dissertação apresentada à Escola de Engenharia de São Carlos da Universidade de São Paulo, como parte dos requisitos para obtenção do Título de Mestre em Engenharia de Produção.

ORIENTADOR: Prof. Dr. Edson Walmir Cazarini

São Carlos

2005 
Ficha catalográfica preparada pela Seção de Tratamento da Informação do Serviço de Biblioteca - EESC/USP

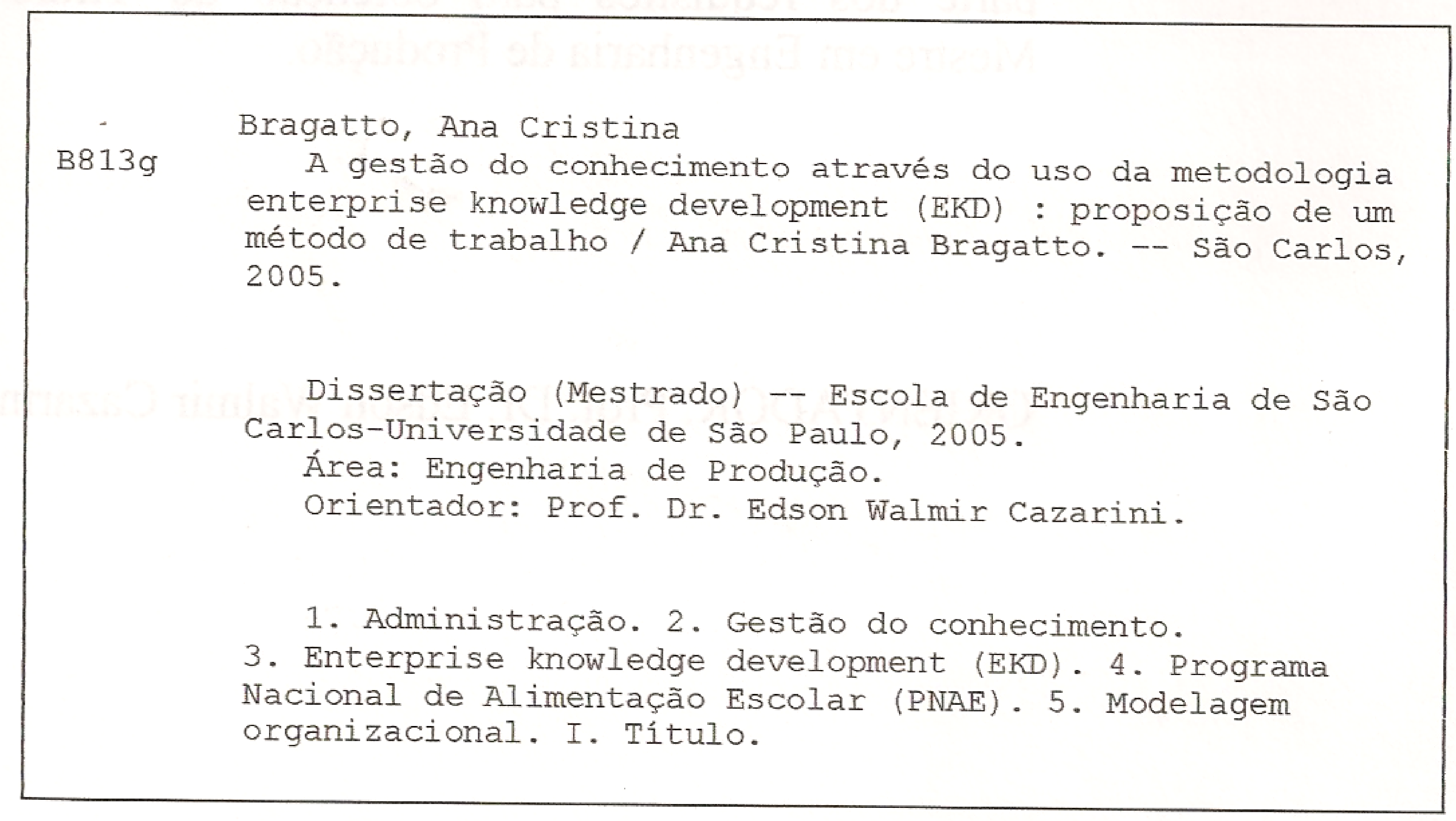




\section{FOLHA DE JULGAMENTO}

Candidata: Bacharel ANA CRISTINA BRAGATTO

Dissertação defendida e julgada em 21-01-2005 perante a Comissão Julgadora:
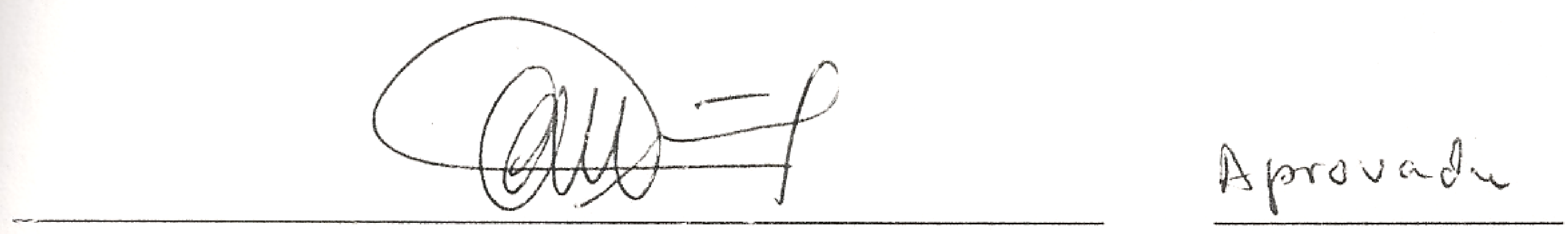

Prof. Dr. EDSON WALMIR CAZARINI (Orientador)

(Escola de Engenharia de São Carlos/USP)

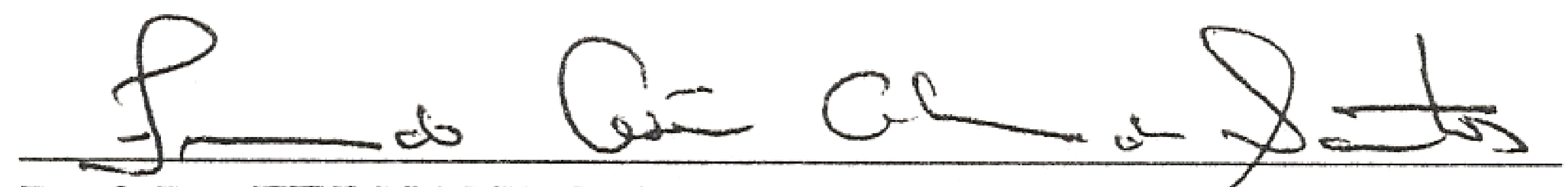

Prof. Dr. FERNANDO CESAR ALMADA SANTOS

(Escola de Engenharia de São Carlos/USP)
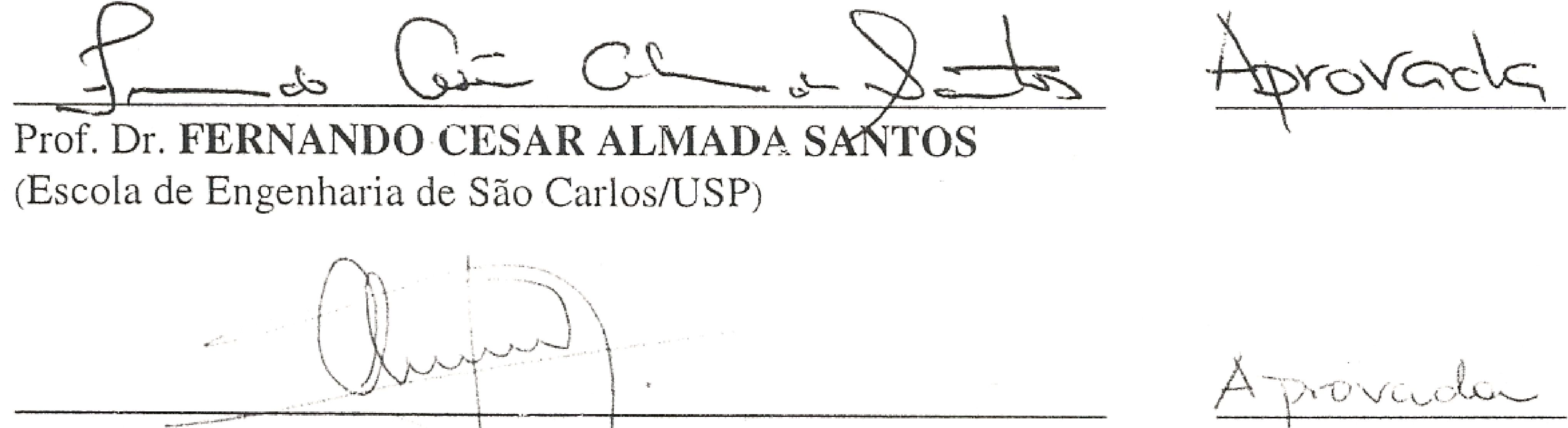

Profa. Dra. ETHEL CRISTINA CHIARI DA SILVA

(Universidade de Ribeirão Preto/UNAERP)

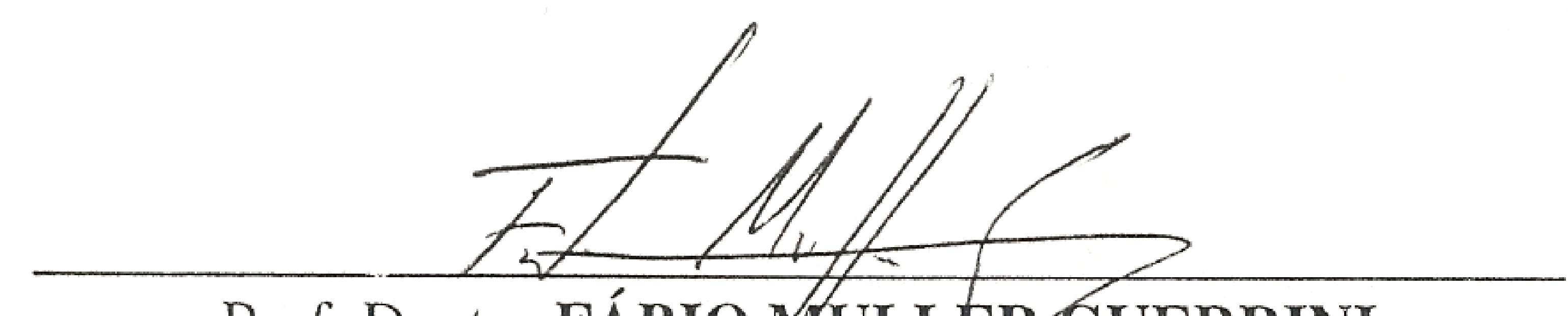

Prof. Doutor FÁBIO MULLER GUERRINI

Vice-Coordenador do Progran de Pós-Graduação em Engenharia de Produção, em exercício.

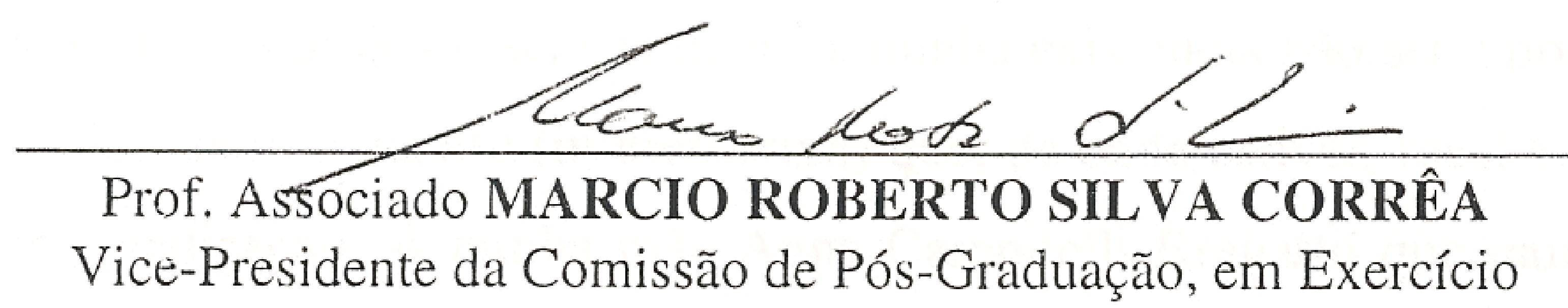


Dedico este trabalho a duas pessoas, sem as quais, a minha existência não seria possível: Ao meu pai Flavio Armando Bragatto (in memorian) que, de onde estiver, receba-o com todo o meu amor e dedicação. À minha mãe Anna Campitelli Bragatto que muito me orgulha com seu exemplo de força, coragem e compreensão e, ao meu companheiro Gustavo, pelas experiências inesquecíveis em nossa vida conjugal. 


\section{AGRADECIMENTOS}

Agradeço a Deus que me dotou de força de vontade e determinação, proporcionando assim, a finalização deste trabalho, após vários momentos de dificuldades e obstáculos encontrados pelo caminho.

Ao Professor Dr. Edson Walmir Cazarini que, com muita compreensão, amizade e carinho, manteve-se ao meu lado nesta tarefa.

Ao Professor Dr. Edmundo Escrivão Filho que, desde meu primeiro dia no Departamento de Engenharia de Produção, me recebeu e me encaminhou. Depois, com muita compreensão, acompanhou toda a minha história no Departamento e fora dele.

Ao Professor Dr. Fernando César Almada Santos, um amigo que muitas vezes colaborou, concordando e discordando em alguns aspectos deste trabalho, mas sempre com muita ética e profissionalismo.

À Professora Dra. Ethel Cristina Chiari da Silva que se tornou uma amiga e muito me ajudou até chegar a este momento, tão significativo em minha vida.

Devo agradecer também aos meus familiares que, junto a mim, suportaram meus momentos de angústia, de dificuldades e que hoje, possam compartilhar desta alegria.

Às minhas amigas e colegas de profissão que não me permitiram desistir e, cuja colaboração e compreensão foram indispensáveis. 


\section{RESUMO}

BRAGATTO, A. C. (2004). A Gestão do conhecimento através do uso da metodologia Enterprise Knowledge Development (EKD): Proposição de um método de trabalho. 150p. Dissertação (Mestrado) - Escola de Engenharia de São Carlos. Universidade de São Paulo. São Carlos, 2004.

Para atender às cambiantes exigências coletivas, numa sociedade cada vez mais complexa, a Administração Pública deve estar em permanente processo de aperfeiçoamento e modernização, sempre ocupada com a eficiência dos serviços que presta à sociedade, às empresas e aos cidadãos. A prestação de serviços Públicos é a razão de ser e condição de legitimidade de qualquer organização administrativa. Apesar da escassez de processos de qualidade e gerenciamento, cultura de atendimento, memória organizacional, na Administração Pública existe uma enorme riqueza de conhecimento tácito em verdadeiros portais humanos. Há um número de especialistas muito bem formados e com décadas de experiência, sendo um dos grandes desafios conseguir explicitar e compartilhar todo esse conhecimento. Neste sentido o presente trabalho tem como objetivo: Propor um método de trabalho que, utilizando como referencial os modelos da Enterprise Knowledge Development (EKD), desenvolva-os através das atividades da Gestão do Conhecimento, utilizando informações do setor de Alimentação Escolar do município de São Carlos, SP. Como um dos principais benefícios pretendidos com o método de trabalho pode-se citar o enriquecimento dos profissionais do setor que, dotados de novos conhecimentos e conhecimentos compartilhados, estejam aptos a disseminá-los e aplicá-los como forma de controle e produtividade.

Palavras-chave: administração; gestão do conhecimento; enterprise knowledge development (EKD); Programa Nacional de Alimentação Escolar (PNAE); modelagem organizacional. 


\section{ABSTRACT}

BRAGATTO, A. C. (2004). The Knowledge Managment through the use methodology Enterprise Knowledge Development (EKD): Propose a work method. 150p. Dissertation (Mastership) - São Carlos Engineering School, São Paulo University, São Carlos, 2004.

To attend the variable collective demand, in a society that is getting each day more complex, the public administration must be in a permanent process of development and modernization, always worried about the efficiency of the service that offers to society and businesses. Public service providing is the reason of existence and condition of legitimacy of any business. Even though public administration lacks of quality and management process, serving culture, organizational memory, there exist an enormous wealth of tacit knowledge. There are in the public sector a great number of specialists with awesome degrees and with decades of experience, so there is a great challenge to explicit and share the knowledge. In this way the present work has an objective: Propose a work methodology, utilizing the referential model of Enterprise Knowledge Development, that develops them through the activities of Knowledge Management utilizing information from the school lunch of the publics schools in São Carlos. The most important benefits intended with this working methodology are the enrichment of the professionals from this area, who with knowledge in hands and shared knowledge, are able to spread this knowledge and apply it in a way that will improve the control and productivity in the schools of the public sector.

Key-words: administration; Knowledge Management; enterprise knowledge development (EKD); national program of the school lunch ; organizational Modeling. 


\section{LISTA DE FIGURAS}

FIGURA 1 - O cenário ambiental da evolução dos modelos de gestão 48

FIGURA 2 - Conteúdo do conhecimento criado pelos quatro modos de conversão 52

FIGURA 3 - Atividades da gestão do conhecimento 64

FIGURA 4 - Sub modelos que compõem o modelo organizacional da EKD 70

FIGURA 5 - Notações do modelo de objetivos (MO) 72

FIGURA 6 - Notações do modelo de regras do negócio (MRN) 74

FIGURA 7 - Notações do modelo de conceitos (MC) 75

FIGURA 8 - Componentes do modelo de processos do negócio (MPN) 76

FIGURA 9 - Componentes do modelo de atores e recursos (MAR) 77

FIGURA 10 - Número de unidades e alunos atendidos por tipo de atendimento realizado pela alimentação escolar - São Carlos, SP. mar. 2004

FIGURA 11 - Gráfico indicando a proporcionalidade de unidades escolares atendidas $\quad 83$

FIGURA 12 - Gráfico indicando a proporcionalidade de alunos atendidos 84

FIGURA 13 - Níveis escolares da educação básica de acordo com a Lei 9.394/96 84

FIGURA 14 - Organograma da secretaria municipal de educação e cultura 85

FIGURA 15 - Organograma administrativo da divisão de alimentação escolar de São $\quad 86$ Carlos, SP.

FIGURA 16 - Modelo de objetivos da divisão de alimentação escolar de São Carlos, SP. 96

FIGURA 17 - Tipos de cardápios adotados em São Carlos, SP 101

FIGURA 18 - Modelo para o entendimento de refeição e preparação - São Carlos, SP. 101

FIGURA 19 - Modelo da $1^{\text {a }}$ semana do cardápio de creches - 2 a 3 anos - São Carlos, SP. 102

FIGURA 20 - Modelo de relacionamento para o processo 1.1 - elaborar cardápios 104

FIGURA 21 - Modelo de relacionamento para o processo 1.2 - documentar cardápios 105

FIGURA 22 - Modelo de relacionamento para o processo 1.3 - distribuir cardápios 106

FIGURA 23 - Classificação dos gêneros utilizados na alimentação escolar em São Carlos, 108 SP. 


\section{LISTA DE QUADROS}

QUADRO 1 - Origem da administração pública

QUADRO 2 - Artigos relacionados ao tema da alimentação escolar encontrados em busca bibliográfica internacional 1995 


\section{LISTA DE TABELAS}

TABELA 1 - Dados estatísticos sobre recursos aplicados e clientela atendida pelo PNAE 
LISTA DE SIGLAS

$\begin{array}{ll}\text { ABN } & \text { Arquivos Brasileiros de Nutrição } \\ \text { APAE } & \text { Associação de Pais e Amigos dos Excepcionais } \\ \text { CAE } & \text { Conselho de Alimentação Escolar } \\ \text { CME } & \text { Campanha de Merenda Escolar } \\ \text { CNA } & \text { Comissão Nacional de Alimentação } \\ \text { CNAE } & \text { Campanha Nacional de Alimentação Escolar } \\ \text { CNAS } & \text { Conselho Nacional de Assistência Social } \\ \text { CNME } & \text { Campanha Nacional de Merenda Escolar } \\ \text { DAE } & \text { Divisão de Alimentação Escolar } \\ \text { DFD } & \text { Diagrama de fluxo de dados } \\ \text { EE } & \text { Entidade Executora } \\ \text { EE.s } & \text { Escolas Estaduais } \\ \text { EESC } & \text { Escola de Engenharia de São Carlos } \\ \text { EKD } & \text { Enterprise Knowledge Development }\end{array}$

ELEKTRA Electrical Enterprise Knowledge for Transforming Applications

EMEBs Escolas Municipais de Educação Básica

EMEIs Escolas Municipais de Educação Infantil

EUA Estados Unidos da América

FAE Fundação de Assistência ao Estudante

FAO Food and Agriculture Organization

FISI Fundo Internacional de Socorro à Infância

FNDE Fundo Nacional de Desenvolvimento da Educação

GC Gestão do Conhecimento

INEP Instituto Nacional de Estudos e Pesquisas Educacionais

INSS Instituto Nacional do Seguro Social

Kcal Caloria

KM Knowledge Management

LDB Lei de Diretrizes e Bases da Educação

MAR Modelo de Atores e Recursos

MC Modelo de Conceitos

MEC Ministério da Educação 


$\begin{array}{ll}\text { MO } & \text { Modelo de Objetivos } \\ \text { MPN } & \text { Modelo de Processos do Negócio } \\ \text { MRCT } & \text { Modelo de Requisitos e Componentes Técnicos } \\ \text { MRN } & \text { Modelo de Regras do Negócio } \\ \text { OMS } & \text { Organização Mundial de Saúde } \\ \text { ONU } & \text { Organização das Nações Unidas } \\ \text { P } & \text { Proteína } \\ \text { PIB } & \text { Produto Interno Bruto } \\ \text { PME } & \text { Programa de Merenda Escolar } \\ \text { PNAE } & \text { Programa Nacional de Alimentação Escolar } \\ \text { PRONAN } & \text { Programa Nacional de Alimentação e Nutrição } \\ \text { SISU } & \text { Swedish Institute for Systems Development } \\ \text { SMEC } & \text { Secretaria Municipal de Educação e Cultura } \\ \text { TI } & \text { Tecnologia da Informação } \\ \text { TIC } & \text { Tecnologia da Informação e Comunicação } \\ \text { UNESCO } & \text { United Nations Educational Scientific and Cultural Organization } \\ \text { UNICEF } & \text { United Nations International Children Emergency Fund } \\ \text { USAID } & \text { Agency for International Development } \\ \text { USP } & \text { Universidade de São Paulo }\end{array}$


RESUMO

ABSTRACT

1 INTRODUÇÃO 1

1.1 Contexto 1

1.2 Determinação do problema 5

1.3 Justificativa 9

1.4 Objetivo 12

$\begin{array}{ll}1.5 \text { Motivação para a pesquisa } & 12\end{array}$

$\begin{array}{ll}1.6 \text { Questões de pesquisa } & 14\end{array}$

$\begin{array}{ll}1.7 \text { Metodologia } & 15\end{array}$

1.8 Organização do trabalho 16

2 ADMINISTRAÇÃO E GESTÃO PÚBLICAS 18

2.1 Considerações iniciais 18

2.2 Origem da administração pública 19

2.3 Definição de administração pública e suas características 21

2.4 Administração pública brasileira 23

2.4.1 Administração direta e indireta 23

2.5 Os princípios básicos da administração pública brasileira 26

2.6 Gestão pública brasileira 29

2.7 Dirigentes e funcionários públicos 32

2.8 Propostas para mudanças na administração pública brasileira 35

2.8.1 Dificuldades encontradas $\quad 40$

2.9 Considerações finais 41

3 GESTÃO DO CONHECIMENTO (GC) 43

3.1 Considerações iniciais 43

3.2 Evolução administrativa e tecnológica 45

3.3 Conhecimento 48

3.3.1 Tipos de Conhecimento 50

3.3.2 Modos de conversão do conhecimento 
3.4 Conceito de gestão do conhecimento (GC)

3.4.1 Atividades da gestão do conhecimento 55

3.5 Organizações da gestão do conhecimento 55

3.6 A gestão do conhecimento no setor público 57

3.7 A gestão do conhecimento no Brasil

3.8 Considerações finais $\quad 63$

4 ENTERPRISE KNOWLEDGE DEVELOPMENT (EKD) 66

4.1 Considerações iniciais 66

4.2 Aplicação da metodologia EKD 68

4.3 Modelo organizacional $\quad 69$

4.3.1 Modelo de Objetivos (MO) 71

4.3.2 Modelo de Regras do Negócio (MRN) 73

$\begin{array}{ll}\text { 4.3.3 Modelo de conceitos } & 74\end{array}$

4.3.4 Modelo de Processos do Negócio (MPR) 75

4.3.5 Modelo de atores e recursos (MAR) 77

4.3.6 Modelo de requisitos e componentes técnicos (MRCT) 78

4.3.7 Relacionamentos entre os sub-modelos 78

$\begin{array}{ll}4.4 \text { Considerações finais } & 79\end{array}$

5 PROPOSIÇÃO DO MÉTODO DE TRABALHO 81

5.1 Considerações iniciais $\quad 81$

$5.2 \mathrm{O}$ programa de alimentação escolar no município de São Carlos, SP 81

5.2.1 Das dificuldades encontradas $\quad 87$

5.3 Do método de trabalho 89

5.3.1 Etapa 1 - Apresentação dps propósitos da atividade a ser desenvolvida, definição da equipe de trabalho e a metodologia a ser seguida

5.3.2 Etapa 2 - Desenvolvimento da missão do negócio 91

5.3.3 Etapa 3 - Desenvolvimento dos objetivos do negócio, de acordo com os conceitos tratados pela metodologia Enterprise Knowledge Development (EKD 94

5.3.4 Etapa 4 - Desenvolvimento do modelo de processos do negócio 97

5.3.4.1 Processo 1 - Planejamento de cardápios $\quad 97$

5.3.4.1.1 Modelagem de relacionamento do processo elaborar cardápios $\quad 104$ 
$\begin{array}{ll}\text { 5.3.4.2 Processo 2 - Aquisição dos gêneros } & 107\end{array}$

5.3.4.3 Processo 3 - Recebimento e armazenamento dos gêneros 108

5.3.4.4 Processo 4 - Distribuição dos gêneros 109

5.3.4.5 Processo 5 - Acompanhamento do preparo e consumo nas unidades $\begin{array}{ll}\text { escolares } & 115\end{array}$

5.3.5 Etapa 5 - Desenvolvimento do modelo de atores e recursos 116

5.3.6 Etapa 6 - Desenvolvimento do modelo de regras do negócio 119

5.3.7 Etapa 7 - Desenvolvimento do modelo de conceitos 119

$\begin{array}{ll}5.4 \text { Considerações finais } & 119\end{array}$

6. CONCLUSÕES 120

$\begin{array}{ll}\text { REFERÊNCIAS } & 128\end{array}$

APÊNDICE A - PROGAMA DE ALIMENTAÇÃO ESCOLAR 134 


\section{INTRODUÇÃO}

\subsection{Contexto}

O novo capítulo da Administração Pública, indicado na Constituição pela Emenda $n^{\circ}$. 19/98, inicia-se sob o princípio da eficiência art. 37, caput, agora ao lado dos princípios tradicionais: legalidade, impessoalidade, moralidade e publicidade. (PESSOA, 2004).

É, contudo, após a integração da emenda da Reforma no Texto Constitucional, no processo de sua implementação legislativa na esfera federal, ainda em andamento, que se percebe, com maior nitidez, a concretização de forma persistente e articulada, das linhas de pensamento e das diretrizes conceituais da Nova Administração Pública.

Para Pessoa (2004), diversos são os indícios desta orientação, facilmente detectáveis entre nós:

- adoção de um programa de privatização em larga escala;

- terceirização de diversos serviços públicos importantes;

- adoção de valores gerenciais e de mercado na Administração Pública direta, fundacional e autárquica;

- mentalidade voltada para o mercado e orientação para o cliente;

- redução progressiva dos gastos sociais;

- crescente ênfase no fazer mais com menos, com os ganhos em eficiência;

- administração hierarquizada; ênfase na mudança pelas cúpulas, e não pelas bases;

- separação entre um pequeno núcleo estratégico e uma grande periferia operacional; 
- ênfase no papel do gerente, daí a expressão Administração Gerencial, do técnico, com aumento da tecnocracia e do déficit democrático das novas instituições (agências executivas e agências reguladoras);

- adoção em larga escala do regime celetista em substituição ao estatutário, com possibilidade de dispensa nos moldes privados;

- quebra da estabilidade;

- frequentes cortes orçamentários e aviltamento da situação dos servidores públicos;

- ênfase nos resultados, nas metas com conseqüente flexibilização do princípio da legalidade.

Administração Pública é, assim, tratada como se fosse uma grande empresa, uma grande companhia, conduzida por uma nova tecnocracia de gestores, a quem incumbem atingirem metas e resultados, sob pena de serem exonerados, à semelhança do que ocorre com grandes executivos no setor privado. (PESSOA, 2004).

Não resta dúvida que a complexa Administração Pública brasileira, tem-se revelado historicamente, e por influência de fatores diversos, patrimonialista, clientelista, burocrática, centralizadora, esbanjadora, ineficiente e com baixo nível de desempenho. (PESSOA, 2004).

A isso pode ser acrescida a ineficiência persistente dos mecanismos institucionais de controle externo (legislativo e tribunais de contas) e interno (controle administrativo) e a impunidade histórica dos maus gestores.

Muitas vezes, em meio a uma lógica burocrática e perversa, desvinculada de políticas públicas, a Administração Pública parece esquecer sua vocação primeira: o serviço à sociedade, serviço este que deve ser prestado de forma eficiente. (PESSOA, 2004).

Para Oliveira (2004), “Uma cena está prestes a se repetir, nos mais diferentes rincões do País". A perplexidade dos governantes diante da extensão das tarefas que têm a cumprir e da precariedade dos instrumentos disponíveis. De um lado, a imensa e 
diversificada agenda de mudança tão defendida na campanha e, do outro, uma máquina pública complexa, que não consegue responder pronta e eficientemente às demandas e solicitações do governante.

Ainda na mesma linha de raciocínio, para Oliveira (2004) a gestão pública constitui um fator fundamental para a melhoria da prestação dos serviços ao cidadão e para o aumento da eficiência das ações governamentais. É justamente o que aponta o amplo movimento que se observa em quase todos os países, no sentido da reforma e modernização do aparelho público. Não obstante, a questão da capacidade da administração pública para atender e viabilizar os compromissos assumidos passou praticamente ao largo das discussões nas últimas campanhas eleitorais, em todos os níveis.

Adota-se o pressuposto de que bastaria ter vontade política e colocar especialistas competentes nos cargos chaves que todos os problemas seriam resolvidos ou, ainda, de que a mobilização da campanha, a legitimidade dos novos governantes e a ocupação da máquina pelos militantes dos partidos vencedores são suficientes para superar todas as restrições e colocar automaticamente a administração pública a serviço do governo. (OLIVEIRA, 2004).

Não se pode esquecer que será necessário criar incentivos e condições para que haja um alinhamento da administração pública ao programa de governo. É preciso que a administração pública, à semelhança da iniciativa privada, aprenda a distinguir e a recompensar os resultados e os esforços excepcionais, incorporando definitivamente a prática de tratar desigualmente as diferenças de contribuição.

Os órgãos e os servidores públicos devem ser estimulados, através de mecanismos de reconhecimento, a buscar princípios, modelos e posturas que efetivamente agreguem valor, em termos da prestação dos serviços à população. Atender melhor ao cidadão, ampliar os serviços à população, reduzir custos e aumentar a produtividade são objetivos que não podem deixar de ser premiados. 
Para que esses objetivos sejam alcançados, é fundamental a implantação efetiva do profissionalismo na administração pública, em termos tanto dos servidores, quanto das instituições. Apesar de simples na sua enunciação, esta linha de ação requer uma série de medidas e compromissos bastante exigentes e complexos na sua implantação. (OLIVEIRA, 2004).

Dos funcionários públicos, a profissionalização deverá requerer criatividade, empreendedorismo e, acima de tudo, alinhamento ativo às diretrizes do governo, independente de suas preferências políticas pessoais, sem implicar evidentemente em afastamento da ética que deve presidir o comportamento do servidor público. Quanto às instituições públicas, as exigências voltam-se para a criação e implantação de condições internas que promovam a profissionalização de seus quadros e estimulem a obtenção de altos desempenhos.

Já quanto ao governo e aos órgãos controladores, a profissionalização da gestão pública representa igualmente um grande desafio. É altamente desejável a adoção de formas de controle menos burocráticas e mais voltadas para resultados, sem desprezar evidentemente a lisura dos processos e o adequado e honesto uso dos recursos públicos.

Cabe ao governo e aos órgãos controladores estimular e distinguir as instituições de desempenho e comportamento exemplares, em termos do cumprimento de suas missões e atendimentos às políticas governamentais. Da mesma forma como o servidor público deve assumir um comportamento profissional em relação ao governo, respeitando e atuando na implementação das prioridades dos governantes eleitos, o inverso também é verdadeiro.

O governo tem igualmente que assumir atitudes e definir medidas que assegurem e signifiquem o fortalecimento da gestão e do comportamento profissionais na administração pública, segundo o prisma de que o servidor público, em última análise, é funcionário do Estado e não do governo. Neste caso, é fundamental que os governos adotem uma visão de longo prazo, visando à profissionalização da máquina pública. Até mesmo porque, no momento em que soluções puramente financeiras e fiscais voltadas para aumento de superávits primários e de impostos tendem a se 
esgotar, uma administração competente, criativa e empreendedora pode desenvolver soluções para redução de custos ou para aumento de receita e produtividade, sem perdas significativas de eficácia, de efetividade e de atendimento às políticas públicas. (OLIVEIRA, 2004).

Muitos são os exemplos, em todo o país, de situações em que processos de melhoria de gestão de entidades públicas eliminaram definitivamente, ou postergaram por alguns anos, a necessidade de aplicação de vultosos volumes de recursos em novos investimentos.

A promoção da valorização e da profissionalização da gestão e do servidor público constituem, provavelmente, um dos investimentos mais rentáveis para o País, tendo em vista a efetiva implantação das políticas públicas e o uso mais racional e eficiente dos recursos que a sociedade coloca à disposição de seus governantes. (OLIVEIRA, 2004).

\subsection{Determinação do problema}

Para atender às cambiantes exigências coletivas, numa sociedade cada vez mais complexa, a Administração Pública deve estar em permanente processo de aperfeiçoamento e modernização, sempre ocupada com a eficiência dos serviços que presta à sociedade, às empresas e aos cidadãos. A prestação de serviços públicos é a razão de ser e condição de legitimidade de qualquer organização administrativa.

Para a administração pública na Sociedade de Informação, novos agentes (munícipes, por exemplo, individualmente ou associados em grupos) também necessitam de informações para poder exercer plenamente a cidadania ou suas atividades (vereadores, imprensa) utilizando os serviços públicos ofertados, demandando novos, controlando efetivamente a ação do governo, cobrando soluções para problemas, fiscalizando a ação e a aplicação dos recursos públicos etc. 
Pode-se, então, imaginar que todas as informações devem ser armazenadas e disponibilizadas. Todavia, com novos agentes e novas formas de utilização de informações e conhecimento, não é possível saber antecipadamente qual e como uma informação armazenada deverá ser disponibilizada.

Neste sentido, é que está sendo desenvolvido o presente trabalho que, apoiado teoricamente em conceitos resultantes de pesquisas acadêmicas e aplicações práticas, propõe a utilização da metodologia de Modelagem Organizacional Enterprise Knowledge Development (EKD) integrada a aplicação dos conceitos e atividades da Gestão do Conhecimento como colaboradora para a melhoria da Gestão Pública.

Nos últimos anos, a Gestão do Conhecimento (GC) emergiu como um dos temas mais importantes na bibliografia sobre gestão empresarial. Já são vários os cursos de nível de pósgraduação tratando do tema, e muitas empresas, inclusive no Brasil, começaram a criar cargos do tipo "gerente de Gestão do Conhecimento". Esse importante movimento e soluções, entretanto, está em sua forma mais visível, limitado às necessidades e condições da grande empresa. (KRUGLIANSKAS e TERRA, 2003).

Para Terra (2003a), Gestão do Conhecimento significa organizar as principais políticas, processos e ferramentas gerenciais e tecnológicas à luz de uma melhor compreensão dos processos de geração, identificação, validação, disseminação, compartilhamento e uso dos conhecimentos estratégicos para gerar resultados econômicos para a empresa e benefícios para os colaboradores.

De acordo com Kruglianskas e Terra (2003) a Gestão do Conhecimento tem caráter universal, ou seja, faz sentido tanto para empresas de setores tradicionais como para empresas em setores de ponta, para empresas em setores primários como para empresas em setores manufatureiros ou de serviços. O uso da Gestão do Conhecimento não se limita, por exemplo, ao chão de fábrica, ao departamento de novos produtos ou áreas em contato com os clientes.

Na administração pública, de acordo com Teixeira Filho e Oliveira (2001), existem algumas carências constatadas: falta memória organizacional, faltam processos 
de qualidade e gerenciamento, falta cultura de atendimento a clientes, falta até mesmo autoconfiança e esperança no futuro, principalmente entre os níveis hierárquicos inferiores. Mas, por outro lado, há uma enorme riqueza em conhecimento tácito, em verdadeiros portais humanos. Há um número enorme de especialistas muito bem formados e com décadas de experiência. Um dos principais desafios, inclusive, para muitas dessas organizações é explicitar e compartilhar todo esse conhecimento, antes que essas pessoas se aposentem ou morram. Porque além de tudo, a maioria das organizações públicas tem equipes envelhecidas e não tem recebido novos talentos ha muito tempo.

Para Teixeira Filho (2002), a perda de conhecimento tácito nas organizações públicas é um dos principais problemas, na ótica da Gestão do Conhecimento, e não pode ser resolvido simplesmente pelo uso de novas tecnologias.

A criação e manutenção de memória organizacional, também na administração pública, passa por diretrizes gerenciais coerentes, processos de trabalho adequados, equipes preparadas e diversos outros aspectos não relacionados diretamente à tecnologia. E com organizações públicas que não têm investido em pessoal, não têm renovado sistematicamente seus quadros e não têm se preocupado com a retenção do conhecimento, o país corre o risco sério de perder seus melhores valores para o setor privado - nacional ou estrangeiro - ou de ver seus profissionais mais experientes se aposentarem, sem terem a quem repassar os conhecimentos adquiridos. (TEIXEIRA FILHO, 2002).

Mais do que simples promessas, eficiência e moralidade na condução dos negócios públicos foram compromissos assumidos pela maioria dos candidatos, eleitos ou não, durante suas campanhas. Sabem eles seja qual for agora seu futuro político, que a construção de um país mais justo passa necessariamente pelo gerenciamento equilibrado dos recursos custeados por uma população cada vez mais atenta e pronta a cobrar fidelidade e valores como ética e transparência. (PORTUGAL, 2002).

Com o intuito de modernizar seus modelos de gestão, instituições governamentais encontram-se num processo contínuo de mudança de atitude, 
aperfeiçoamento e reorganização das rotinas internas necessário para ajustar a administração pública aos desafios impostos por recursos mais escassos, pelas novas demandas da sociedade e pela maior consciência da necessidade de rigor no trato de um bem que não é privado, que pertence a uma nação inteira. (PORTUGAL, 2002).

Neste sentido, este trabalho busca a aplicação dos conceitos e práticas da Gestão do Conhecimento na administração pública, sendo necessário que as ferramentas, a linguagem e as práticas gerenciais relacionadas à Gestão do Conhecimento sejam adaptadas às possibilidades, aos desafios e às condições financeiras da Administração Pública.

Para que isso ocorra será realizada a proposição de um método para aplicação dos conceitos e atividades da Gestão do Conhecimento utilizando como ferramenta os princípios teóricos da Enterprise Knowledge Development (EKD) na prática a ser adotada que considerará informações do setor de Alimentação Escolar do município de São Carlos, SP.

A Enterprise Knowledge Development (EKD) é uma metodologia desenvolvida para a modelagem organizacional e, neste trabalho, será utilizada no gerenciamento do conhecimento organizacional para formar a base de propagação e ampliação de conhecimentos no setor escolhido e mencionado anteriormente.

O Modelo Organizacional da Enterprise Knowledge Development (EKD) oferece o referencial para que se obtenha, aplicando as atividades da Gestão do Conhecimento, um conhecimento coletivo aos integrantes de uma equipe de trabalho, setor ou organização, dependendo do contexto que será aplicada. 


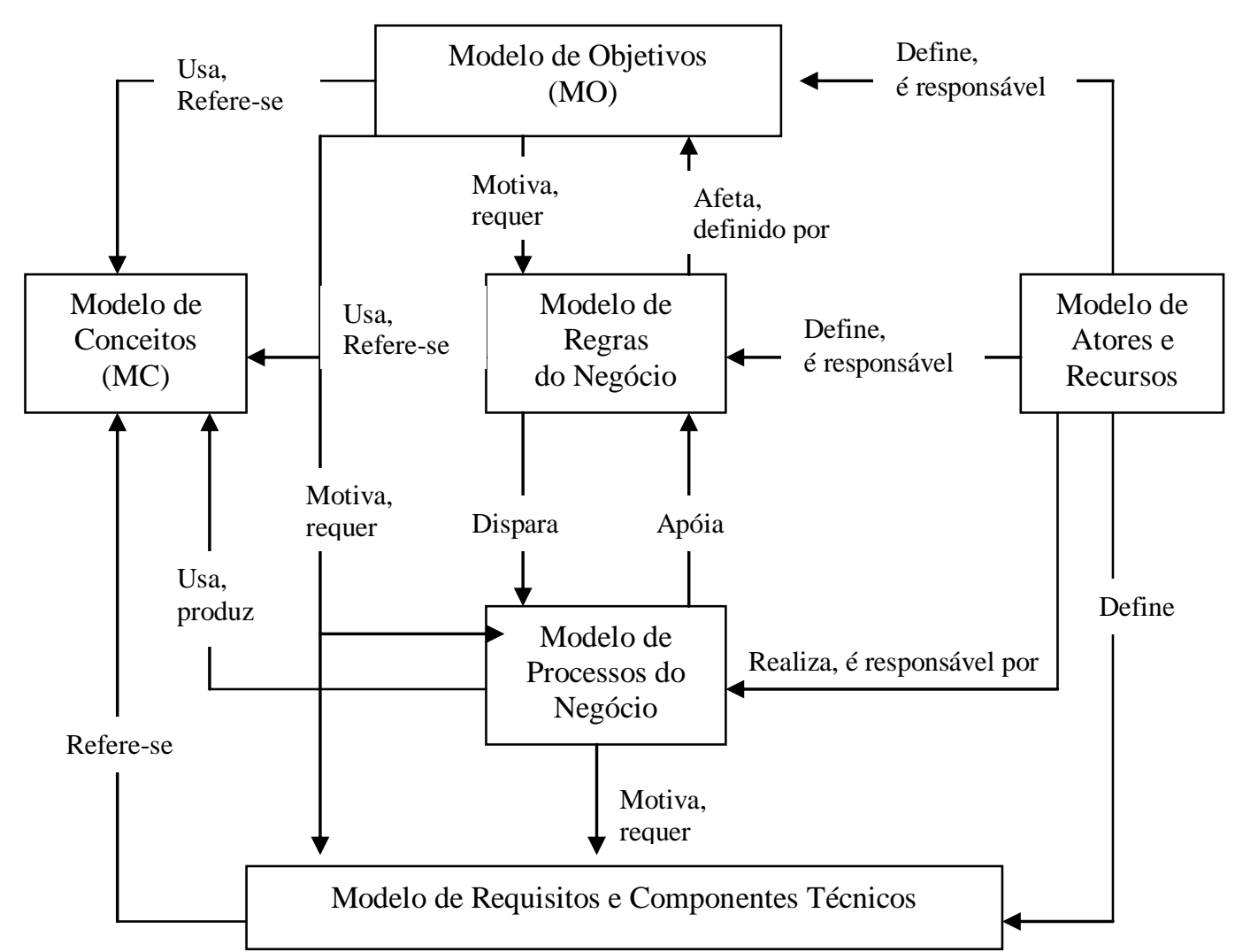

Figura 05, Capítulo 4 - Submodelos que compõem o Modelo Organizacional da EKD. Fonte: BUBENKO et al. (1998) apud PÁDUA (2001, p.80)

\subsection{Justificativa}

Andrade e Tomaz (2003) afirmam que a escassez de livros publicados sobre gestão do conhecimento é notória e os poucos que existem são em geral, ou muito genéricos ou muito fragmentados, apresentando alguns modelos, dicas, casos e métodos sem introduzir uma metodologia consistente para facilitar a gestão do conhecimento integrada a conceitos, modelos e casos práticos coerente, funcional e adaptada à realidade brasileira.

Na maioria dos casos de organizações públicas brasileiras, ainda se está no nível da mudança tecnológica. Ainda não se tem mudanças profundas, nem de processos de trabalho, nem de gerenciamento, nem na cultura organizacional. Esses são pontos que precisarão ser atacados para implantação de Gestão do Conhecimento no espaço público de forma mais concreta, consistente e duradoura. Caso contrário corre-se o risco de ficar 
ao sabor da moda da tecnologia, incorporando funcionalidades novas sem resolver os problemas centrais da administração pública. (TEIXEIRA FILHO, 2002).

Embora existam especificidades no presente trabalho, acredita-se na sua utilidade como fio condutor de experiências similares a fim de se adquirir segurança e buscar soluções personalizadas sem gastar muito dinheiro, desenvolvendo seu próprio projeto de gestão do conhecimento e, mais tarde, transformando-o no sistema de gestão do setor escolhido.

Neste contexto procura-se superar problemas, lançando mão das vantagens decorrentes de aspectos culturais de nosso país, como, por exemplo, a criatividade, flexibilidade e sociabilidade do povo brasileiro. (Andrade e Tomaz, 2003).

Pode-se também, considerar a oportunidade de enriquecimento das atividades desenvolvidas pelo grupo de Sistemas de Apóio à Decisão do Departamento de Engenharia de Produção da Escola de Engenharia de São Carlos - Universidade de São Paulo, trazendo ao conhecimento de todos os seus envolvidos, através da finalização desta pesquisa, o tema deste trabalho: A utilização da Enterprise Knowledge Development (EKD) para o desenvolvimento da Gestão do Conhecimento na Administração do serviço público de Alimentação Escolar.

A viabilidade ao acesso detalhado às informações torna-se possível pelo vínculo profissional desta autora e, pela aplicação de conhecimentos adquiridos sobre novos conceitos de Gestão e metodologia de modelagem organizacional proporcionados pelo Departamento de Engenharia de Produção.

Os benefícios que se buscam com a aplicação prática das atividades da Gestão do Conhecimento através dos modelos da Enterprise Knowledge Development (EKD) são, entre outros:

- Introdução aos conceitos básicos de Gestão do Conhecimento e da metodologia de modelagem organizacional Enterprise Knowledge Development (EKD) a fim de situar os envolvidos no trabalho a ser realizado; 
- Definição clara do modelo de negócio do Setor de Alimentação. A idéia é construir coletivamente elementos básicos como missão, visão, valores, cargos, funções, objetivos de curto e longo prazo; bem como envidar esforços para que o modelo de negócio faça parte da vida dos servidores do Setor, e não consista apenas de palavras eloqüentes em cartazes;

- Identificação e codificação dos processos de negócio: para que os servidores tenham melhor percepção da cadeia de valor que envolve o trabalho deles, bem como servir de ponto de partida para a reinvenção de processos;

- Aumento de produtividade: com o armazenamento organizado dos documentos produzidos ao longo do tempo, as pessoas poderão recuperar com maior facilidade trabalhos que possam ser usados como base para novos produtos;

- Agrupar os conhecimentos: o objetivo é que as pessoas consigam encontrar com mais facilidade as respostas para suas perguntas;

- Diminuir a dependência de acesso a informações e conhecimentos das pessoas que os detêm: que as informações e conhecimentos deixem cada vez mais de residir somente nas cabeças, gavetas e microcomputadores das pessoas e passem a estar disponíveis para seus colegas;

- Disseminar experiências obtidas em processos importantes: um processo que gere polêmicas e/ou que demande reflexões relevantes pode gerar muito conhecimento para os envolvidos, independentemente do resultado, ser positivo ou negativo. E essa experiência pode ser transmitida para seus colegas;

- Processo de inovação consciente: a partir da preocupação em se criar novos processos, pode-se partir para grupos de trabalho interdisciplinares de forma que seja garantido o grau de diversidade de idéias necessário (não haja paradigmas dominantes) e que tenham como objetivos produzir inovações e formatar os resultados dos esforços dos grupos para que sejam aproveitados por seus pares; 
- Melhorias de processos: novas formas de fazer as coisas podem ser conhecidas e absorvidas pelos servidores do Setor.

\subsection{Objetivo}

O presente trabalho busca: Propor um método de trabalho que, utilizando como referencial os modelos da Enterprise Knowledge Development (EKD), desenvolva-os através das atividades da Gestão do Conhecimento, utilizando informações do setor de alimentação escolar do município de São Carlos, SP.

Alguns objetivos secundários são necessários para que se atinja o objetivo anteriormente apresentado:

- Pesquisar conceitos, práticas e a situação atual da Administração Pública;

- Pesquisar conceitos e atividades da Gestão do Conhecimento;

- Pesquisar conceitos da metodologia para modelagem organizacional Enterprise Knowledge Development (EKD);

- Levantar informações pertinentes ao presente trabalho junto ao Setor de Alimentação Escolar do município de São Carlos.

\subsection{Motivação para a pesquisa}

Apesar dos avanços acadêmicos e tecnológicos que disponibilizam ferramentas cada vez mais eficazes para o suporte à gestão administrativa e às novas formas de gestão, pode-se encontrar em setores da economia brasileira, em especial, na Administração Pública, uma extrema precariedade destes recursos.

Em decorrência de experiências vivenciadas através do desenvolvimento de uma carreira profissional e acadêmica, a autora, afirma que pôde, em vários momentos, detectar a desconexão existente entre teoria e prática.

Esta desconexão acabou por despertar o interesse em abordar um assunto profissional, o Programa Nacional de Alimentação Escolar juntamente com a área de 
pesquisa deste mestrado: Sistemas de Apoio à Tomada de Decisões, buscando na prática, o aperfeiçoamento e adequação de gestão, possibilitados pela teoria.

Outro fato preocupante é que a mídia brasileira, vez ou outra, veicula informações sobre a má aplicação dos recursos dos Programas de Alimentação Escolar, pois como alegam Trevisan et al. (2003, p.21) "as quadrilhas têm aperfeiçoado as suas formas de atuar. Por isso, é preciso que os controles por parte da sociedade também se aprimorem."

Ainda segundo Trevisan et al. (2003) o Tribunal de Contas, um dos órgãos responsáveis pela fiscalização do Programa, acaba por verificar apenas os aspectos formais das despesas, sem entrar no mérito de verificar se a nota fiscal contabilizada é "fria" ou não; se a empresa fornecedora existe legalmente ou não; se o preço do serviço prestado é compatível com o mercado ou não e, se o procedimento licitatório foi conduzido adequadamente ou não.

Essas deficiências colaboram para a falta de profissionalismo, normalmente encontrada nos setores responsáveis pelo Programa de Alimentação Escolar dos municípios. Alguns dos gestores desse Programa, em nível municipal, não se preocupam em implantar normas e procedimentos que o torne transparente e, geralmente, não respeitam as determinações legais em nenhum de seus processos, dentre eles: planejamento de cardápios, aquisições de gêneros, recebimento e estocagem, distribuição de gêneros e controle nas Unidades, quando a realidade for de descentralização no preparo das refeições.

Tohá e Solari (2004), afirmam que a maior transparência na administração é, ao mesmo tempo, uma forma de responder ao público e uma maneira de dinamizar os sistemas de controle, de baixo custo e alta eficácia política. Quando a informação é acessível e clara, quando as contas públicas são exigíveis, o controle dos cidadãos pode tornar-se mais efetivo e adequado que os controles estritamente administrativos. Na época em que a corrupção se transforma num mal tão difundido, esta pode ser uma estratégia para detê-la. 
Basicamente são duas as grandes motivações para a realização deste trabalho:

1. Explorar a metodologia da Enterprise Knowledge Development (EKD) de forma inédita, aplicando seus conceitos e atividades como contribuição à prática da Gestão do Conhecimento que, por sua vez, dificilmente tem sido abordada na literatura existente sobre o tema;

2. Fornecer conhecimentos aos profissionais de carreira do Setor de Alimentação Escolar do município de São Carlos sobre os processos e procedimentos adotados atualmente, que buscam atender à legislação existente, transformando-os em potenciais disseminadores e controladores da execução do Programa de Alimentação Escolar no município.

\subsection{Questões de pesquisa}

Em cada uma das atividades da Gestão do Conhecimento a serem propostas a partir das informações colhidas no Setor, algumas questões fazem-se necessárias tornando-as o fio condutor para as ações quanto à proposição do método pretendido:

Quanto à geração de conhecimentos é importante saber se o Setor de Alimentação tem um modelo de negócio claro e internalizado pelos servidores. Por exemplo, os servidores em geral sabem qual é a missão do Setor? E outros elementos, como visão, valores, cargo, funções, objetivos de curto e longo prazo? Os processos do Setor de Alimentação são bem dominados, padronizados?

$\mathrm{Na}$ atividade de codificação de conhecimentos torna-se necessário avaliar se os processos de trabalho são documentados, de modo que conhecimentos relativos à sua fundamentação e funcionamento não residam apenas nas cabeças de algumas pessoas, o que as torna insubstituíveis e dificulta a realização dessas tarefas por outras pessoas. Se os trabalhos feitos nas unidades são acumulados de forma que são facilmente recuperados, viabilizando o reaproveitamento de trabalho sistemático? E se os trabalhos realizados pelas pessoas ficam guardados de forma restrita ou, são oferecidos para quem possa aproveitá-los no futuro? 
Para a atividade de disseminação de conhecimentos deve-se observar se o conhecimento das pessoas tidas como mais talentosas e/ou experientes são compartilhados por seus pares ou ficam restritos a elas e vão embora com essas pessoas quando deixam o Setor? Os progressos e problemas enfrentados em processos importantes são compartilhados pelos outros servidores, além daqueles envolvidos no processo?

Finalmente, na atividade de apropriação do conhecimento deve-se saber se: é costume ver exposições de novas práticas consideradas inovadoras desenvolvidas e testadas durante execução dos trabalhos do Setor? Os melhores trabalhos são identificados e aproveitados pelos colegas, de modo que uma nova forma de executar uma tarefa possa ser usada como referência pelos demais, fazendo-se com que mais pessoas progridam? As pessoas percebem o resultado de seu esforço para que o Setor execute sua missão e alcance seus objetivos?

\subsection{Metodologia}

A metodologia adotada demonstra como a pesquisa é implementada, o método adotado e as técnicas utilizadas para se alcançar os resultados. Ela é relevante no processo de investigação por ser uma ferramenta que auxilia o pesquisador nas decisões e na orientação de uma conduta eficaz no processo de geração do conhecimento.

O presente trabalho, segundo Gil (1991), é classificado como sendo uma pesquisa exploratória, tendo como objetivo o aprimoramento de idéias ou a descoberta de intuições e assumindo a forma de pesquisa bibliográfica.

Conforme Gil (1991), a pesquisa bibliográfica é desenvolvida a partir de material já elaborado, constituído principalmente de livros, artigos científicos e outras fontes bibliográficas. $\mathrm{O}$ autor afirma ainda que a principal vantagem da pesquisa bibliográfica, é permitir ao investigador a cobertura de uma gama de fenômenos muito mais ampla do que aquela que se teria com a pesquisa direta.

Partindo dos conceitos adquiridos pela pesquisa bibliográfica e, a fim de se atingir o 
objetivo deste trabalho será também utilizada, a pesquisa documental, realizada no setor utilizado para fornecer informações que possibilitem criar coerência para o método proposto.

No contexto considerado - o Setor de Alimentação Escolar do município de São Carlos - o presente trabalho esta voltado, se aplicado, para a tomada de consciência dos agentes implicados na atividade proposta, não tratando apenas de resolver um problema imediato e sim desenvolver a consciência da coletividade nos planos político e cultural a respeito dos problemas importantes que enfrenta ou poderá a vir enfrentar.

\subsection{Organização do trabalho}

O presente trabalho está organizado em seis capítulos:

No Capítulo 1 é apresenta a introdução ao tema abordado, procurando contextualizar a problemática existente em vistas a definir os objetivos, o que motiva a realização deste trabalho, bem como a justificativa para a sua realização, a metodologia a ser utilizada para viabilizar os objetivos propostos e conclusões pertinentes.

O Capitulo 2 ocupa-se em apresentar as origens e características da Administração Pública, as especificidades da Administração Pública brasileira, problemas e a apresentação de propostas de melhoria da Gestão por autores e estudiosos do assunto.

No capítulo 3 tem-se o resultado de pesquisa bibliográfica que fundamenta teoricamente o tema Gestão do Conhecimento e as atividades que serão adotadas no presente trabalho.

No capítulo 4 aborda-se o tema Enterprise Knowledge Development (EKD), metodologia voltada à modelagem organizacional que traz o referencial para um encaminhamento prático e possibilita a documentação dos assuntos a serem abordados no presente trabalho - objetivos, missão, visão, processos, cargos, funções do setor escolhido. 
O capítulo 5 apresenta a proposição de um método que busca contemplar as atividades da Gestão do Conhecimento - Geração, Codificação, Disseminação e Apropriação do conhecimento através da utilização da Enterprise Knowledge Development (EKD), utilizando informações do setor de Alimentação Escolar do Município de São Carlos, SP.

No capítulo 6 são apresentadas as discussões dos resultados e conclusões desta pesquisa, com recomendações para trabalhos futuros.

Na parte final são apresentadas as fontes bibliográficas e um Apêndice no qual é apresentado o Programa de Alimentação Escolar a nível internacional e nacional, envolvendo objetivo, histórico, beneficiários, recursos, Conselho de Alimentação Escolar (CAE) e noções gerais sobre a administração de seus serviços a nível municipal. Este embasamento teórico torna-se necessário para orientar a proposição de método esperada. 


\section{ADMINISTRAÇÃO E GESTÃ̃ PÚBLICAS}

\subsection{Considerações iniciais}

A administração pública passa por um momento de reformas e modernização. Esta afirmação tem sido quase unânime entre os pensadores e escritores do tema.

A população está mais consciente de seus direitos e de sua cidadania e cobra dos seus representantes mais seriedade em suas ações, serviços públicos eficientes, ágeis e de boa qualidade, como forma de compensar a alta carga tributária a que está submetida.

Por não visar lucro, a administração pública, ao longo do tempo não se preocupou em controlar custos e despesas dos seus serviços. Nunca se preocupou com resultados e esqueceu que o seu lucro estava embutido na satisfação e na qualidade de vida das pessoas. (SANTOS et al., 2004).

O gestor público na ausência de dados e ferramentas gerenciais, freqüentemente, é tomado de dúvidas e incertezas, e às vezes, decide errado, por falta de informações que lhe auxilie na tomada de decisão. (SANTOS et al., 2004).

Nesse aspecto, o presente capítulo apresenta o conceito de Administração Pública, suas origens e características. Aborda também as particularidades da Administração Pública Brasileira, como esta se encontra estruturada, quais os princípios básicos que regem a atual administração pública brasileira, as dificuldades encontradas na prática da Gestão Pública e cita propostas de melhoria apresentadas por alguns autores. 
As informações tratadas neste capítulo tornam-se necessárias para que se conheça o contexto a ser utilizado na proposição de um método para a prática da Gestão do Conhecimento.

\subsection{Origem da Administração Pública}

A origem da administração pública remonta à criação dos primeiros centros urbanos. Neste contexto são apresentadas as origens da mesma, pontualmente, respeitando-se as particularidades ocorridas nos diversos continentes e regiões:

\begin{tabular}{|c|c|}
\hline $\begin{array}{c}\text { No antigo Egito e nas } \\
\text { civilizações meso- } \\
\text { americanas e andinas }\end{array}$ & $\begin{array}{l}\text { A adequada distribuição de água de um rio, o cálculo das enchentes anuais, } \\
\text { o estabelecimento da periodicidade das colheitas, a realização das grandes } \\
\text { obras de irrigação, requeriam uma organização complexa e centralizada para } \\
\text { poder surtir efeito. Daí o surgimento da burocracia piramidal dessas } \\
\text { civilizações, integrada por funcionários e sacerdotes que, em diversos níveis } \\
\text { eram responsáveis por determinados setores da atividade social, } \\
\text { respondendo por suas tarefas perante os superiores. }\end{array}$ \\
\hline Nas cidades gregas & $\begin{array}{l}\text { Manteve-se também uma administração complexa. O aparelho } \\
\text { administrativo mais avançado entre os da antiguidade ocidental foi o do } \\
\text { Império Romano. Nesse, dividiu-se a administração pública em diversos } \\
\text { campos segundo os assuntos, criando-se uma ampla rede de funcionários, } \\
\text { que ocupavam todos os domínios de Roma. }\end{array}$ \\
\hline $\mathrm{Na}$ China imperial & $\begin{array}{l}\text { Coube à dinastia Tang, o desenvolvimento, entre os séculos VII e X, de um } \\
\text { sistema administrativo considerado eficaz. Sob a influência do pensamento } \\
\text { confuciano, o sistema foi aperfeiçoado pela dinastia Song ou Sung (960- } \\
\text { 1279). Os candidatos ao posto de funcionário do império eram selecionados } \\
\text { mediante cuidadosos exames, nos quais se comprovavam seus } \\
\text { conhecimentos teóricos e práticos e sua capacidade pessoal para o } \\
\text { desempenho da função escolhida. A eficiência do sistema permaneceu sem } \\
\text { modificações até } 1912 \text {. }\end{array}$ \\
\hline No mundo ocidental & $\begin{array}{l}\text { A queda do Império Romano provocou o fim de seu sistema administrativo, } \\
\text { que só continuou a vigorar, embora de forma atenuada, em Bizâncio. A } \\
\text { igreja ergueu uma administração paralela, que perdura ainda hoje. O poder } \\
\text { civil, muito fragmentado durante a Idade Média européia, não foi capaz de } \\
\text { desenvolver um aparelho administrativo completo antes do advento do } \\
\text { absolutismo no século XVI. A centralização do poder nas mãos dos } \\
\text { monarcas exigiu a criação dos diferentes setores da atividade do estado. }\end{array}$ \\
\hline
\end{tabular}

Quadro 01 - Origem da Administração Pública. Fonte: Encyclopaedia Britannica do Brasil Publicações Ltda (2004). 


\begin{tabular}{|c|c|}
\hline Na Prússia & $\begin{array}{l}\text { O primeiro sistema administrativo com características modernas a surgir na } \\
\text { Europa foi o adotado pela monarquia prussiana durante os séculos XVII e } \\
\text { XVIII. A progressiva militarização e centralização da Prússia só foi possível, } \\
\text { graças à criação de um corpo de funcionários. O sistema de seleção, promoção e } \\
\text { organização interna aperfeiçoou-se e foi objeto de compilação em um código } \\
\text { geral promulgado em 1794. Nele se especificavam os estudos prévios e outros } \\
\text { requisitos que deveriam possuir os funcionários. No código prussiano, encontra- } \\
\text { se o fundamento do funcionalismo moderno. }\end{array}$ \\
\hline No sistema napoleônico & $\begin{array}{l}\text { A coroa francesa havia desenvolvido um dos mais completos sistemas de } \\
\text { burocracia da Europa. A revolução de 1789, ao eliminar a monarquia, provocou } \\
\text { profundas modificações nas bases da administração. O funcionário, em lugar de } \\
\text { servidor do rei, converteu-se em empregado do estado. Napoleão I, seguindo os } \\
\text { princípios de racionalidade, lógica e universalidade herdados do Iluminismo, } \\
\text { criou um sistema administrativo baseado em um rígido encadeamento de } \\
\text { poderes e responsabilidades, elaborando até um código de direito administrativo. } \\
\text { Concedeu-se maior importância ao cargo de funcionário, estabelecendo-se } \\
\text { distinção entre a função e a pessoa que a exercia. O sistema napoleônico não } \\
\text { tardou a ser adotado pelos países da Europa continental. }\end{array}$ \\
\hline No império britânico & $\begin{array}{l}\text { Criou-se um serviço exemplar na Índia, muitos anos antes de implantá-lo na } \\
\text { própria metrópole. Na segunda metade do século XIX, surgiu um sistema de } \\
\text { normas que levou à formação de um eficiente corpo funcional na administração } \\
\text { britânica. }\end{array}$ \\
\hline Nos Estados Unidos & $\begin{array}{l}\text { Não contaram com um corpo profissional de funcionários da administração } \\
\text { pública, idéia que repugnava à mentalidade liberal imperante no século XIX, até } \\
\text { que o desenvolvimento econômico e social surgido após a guerra civil obrigou a } \\
\text { administração federal a multiplicar suas atividades, fazendo-se urgente uma } \\
\text { organização administrativa. Em } 1883 \text {, criou-se a Comissão do Serviço Civil dos } \\
\text { Estados Unidos, que estabeleceu normas para ingresso nos níveis inferiores do } \\
\text { funcionalismo federal. Só na década de } 1920 \text { o sistema foi estendido aos níveis } \\
\text { superiores da administração. }\end{array}$ \\
\hline Nos países socialistas & $\begin{array}{l}\text { A revolução soviética extinguiu o sistema administrativo czarista. Após um } \\
\text { curto período em que se tentou reduzir ao mínimo a burocracia estatal, ficou } \\
\text { patente a necessidade de uma grande organização funcional e um extenso corpo } \\
\text { de especialistas capazes de manejar o aparelho administrativo. Em poucos anos, } \\
\text { a burocratização da União Soviética apresentou efeitos negativos que } \\
\text { prejudicaram o próprio Partido Comunista. Nos países socialistas o partido } \\
\text { passou a controlar não só as decisões políticas, como também os níveis } \\
\text { administrativos inferiores. }\end{array}$ \\
\hline
\end{tabular}

Quadro 01 - Origem da Administração Pública. Fonte: Encyclopaedia Britannica do Brasil Publicações Ltda (2004). 


\subsection{Definição de administração pública e suas características}

De acordo com a Encyclopaedia Britannica do Brasil Publicações Ltda (2004), em todos os países, qualquer que seja sua forma de governo ou organização política, existe uma administração pública. Sem ela não haveria estado, nem poderiam os governantes cumprir suas funções: defesa, ordem, cobrança de impostos etc. Não obstante, a burocracia administrativa por vezes se torna tão ampla e complexa que os próprios governantes temem perder o controle sobre ela.

Administração pública é a ordenação, direção e controle dos serviços do governo, no âmbito federal, estadual e municipal, segundo os preceitos do direito e da moral, visando ao bem comum. Pode ser entendida de três formas: em um primeiro sentido, é o conjunto de entes ou sujeitos de caráter público: os meios, humanos e materiais, de que dispõe o governo para aplicação de suas políticas; em um segundo sentido, é o conjunto de ações encaminhadas para o cumprimento dos programas e políticas dos governos; por fim, enquanto ciência, a administração pública se propõe a estudar as condições que permitem ao direito, emanado dos poderes do estado, concretizar-se da maneira mais eficaz possível, através da atuação dos órgãos administrativos.

Amato $^{1}$ (1971 apud WELS, 2004) agrega a idéia de exercício da ciência política, ao afirmar que:

[...] administração pública significa política, sistema político, sistema de governo. Ou seja, o conjunto de manifestações da conduta humana que determina a distribuição e o exercício da autoridade pública, bem como o tratamento dos interesses públicos.

A administração pública incide, pois, sobre a prática do serviço público, que inclui todas as profissões e todas as habilidades, dentro dos limites das funções e das atividades executadas para a comunidade e para um alcance de todas as áreas e atividades governadas pela política pública.

\footnotetext{
${ }^{1}$ AMATO, P. M., (1971). Introdução à administração pública. Rio de Janeiro: Fundação Getúlio Vargas apud WELS. A. M. C., (2004). Assessorias de comunicação social na esfera pública. Disponível em: <http://www.pucrs.br/famecos/geacor/texto11-03.html>. Acesso em 26 fev. 2004.
} 
Sobre a extensão da área pública WELS, (2004) cita que o âmbito de ação da administração pública concentra-se no ramo executivo do governo, uma vez que é nesta esfera do Poder Público que se encontram atividades que contêm pontos comuns com empresas privadas de produção econômica, e onde se estabelecem questões similares entre empresas públicas e empresas privadas.

Trata-se, assim, da administração responsável pela determinação e execução de normas associadas a aspectos públicos e políticos, que se consolidam em ações das empresas estatais, cuja natureza envolve o atendimento de interesses da sociedade em geral, e que são gerenciadas por políticos eleitos pelo povo ou nomeados por representantes legais, sendo mantidos por cofres públicos e, portanto, com compromisso direto com a comunidade.

As operações administrativas do governo - em seus aspectos de planejamento, organização, métodos, pessoal, relações de trabalho, direção, etc. — são executadas em íntima relação com as atividades de caráter político, com as fórmulas fundamentais da organização governamental e com os propósitos de todo o sistema. (WELS, 2004).

Numa concepção ampla, organização pública e privada se assemelham, entretanto, há fronteiras diferenciadas que percorrem aspectos referentes à transitoriedade dos cargos públicos, políticas de pessoal, gerenciamento de finanças, projetos de desenvolvimento econômico e social e proteção dos interesses públicos.

Além desses aspectos, as organizações públicas caracterizam-se por um perfil burocrático, onde a rigidez da estrutura hierárquica representa, muitas vezes, entraves para decisões e execução de serviços, repercutindo negativamente junto à opinião pública, e estendendo uma impressão singular para todo o complexo administrativo governamental. (WELS, 2004).

O aparelho administrativo executa diferentes funções: tem ingerência nas relações entre particulares, garantindo-lhes maior segurança jurídica, dá publicidade aos atos em que são interessados e realiza sua fiscalização. 
Além dessa ação negativa de condicionamento da liberdade e da propriedade, as repartições administrativas atuam na realização de obras e na prestação de serviços públicos.

A prestação desses serviços à comunidade pressupõe, naturalmente, que o estado disponha dos meios necessários e, por isso, a administração pública, por meio de suas repartições, ordena o pagamento de tributos e regula empréstimos compulsórios, entre outras providências.

\subsection{Administração pública brasileira}

A administração pública no Brasil se desenvolve por meio de três poderes: legislativo, executivo e judiciário, com autonomia e competência específica. Correspondem, respectivamente, às funções legislativa, administrativa e jurisdicional.

Por meio da primeira, o estado formula o direito objetivo ou o põe em execução. Pela função jurisdicional, constata a existência e extensão de uma regra de direito ou de uma situação jurídica, em caso de violação, e ordena as medidas necessárias para assegurar-lhe o respeito.

No tocante à função administrativa, o poder executivo pode ser considerado por meio de duas faces distintas, como entidade política e como gestor da máquina administrativa governamental, cabendo-lhe prover a segurança do estado, a manutenção da ordem pública e a satisfação das necessidades da comunidade. (WELS, 2004).

\subsubsection{Administração direta e indireta}

A administração federal compreende, de acordo com a Encyclopaedia Britannica do Brasil Publicações Ltda, (2004): (1) a administração direta, constituída pelos serviços integrados na estrutura administrativa da presidência da república e pelos ministérios; (2) a administração indireta, que compreende as autarquias, as empresas públicas e as sociedades de economia mista. (ENCYCLOPAEDIA BRITANNICA DO BRASIL PUBLICAÇÕES LTDA, 2004). 
- Administração direta - Entende-se por administração direta o conjunto de órgãos integrados na estrutura administrativa da União. A presidência da república, sob imediata direção do chefe da nação, é o órgão supremo e independente, representante do poder executivo da União. Constitui-se pelo Gabinete Civil, pela Secretaria-Geral, pela Secretaria de Planejamento, Orçamento e Coordenação e pelo Gabinete Militar. Além desses, há outros órgãos de consulta, assessoramento e assistência ao presidente da república.

- Administração indireta - É o conjunto dos entes personalizados que, vinculados a um ministério, prestam serviços públicos ou de interesse público. Integram a administração indireta as autarquias, empresas públicas, fundações públicas e sociedades de economia mista.

Dá-se o nome de autarquia ao serviço autônomo, criado por lei, com personalidade jurídica, patrimônio e receita próprios, para executar atividades típicas da administração pública, que requeiram, para seu melhor funcionamento, gestão administrativa e financeira descentralizada. É pessoa jurídica de direito público, com função pública própria e típica, autorizada pelo estado. Suas principais características são: criação por lei; personalidade jurídica; patrimônio e receita próprios; exercício de atividades típicas da administração pública; autonomia de gestão; e tutela administrativa.

As fundações públicas realizam atividades não lucrativas atípicas do poder público, mas de interesse coletivo, como a educação, cultura e pesquisa. São criadas por lei específica da entidade matriz e estruturadas por decreto, independentemente de qualquer registro. Suas principais características são: (1) dotação específica de patrimônio, gerido pelos órgãos de direção da fundação segundo os objetivos estabelecidos na respectiva lei de criação; (2) participação de recursos privados no patrimônio e nos dispêndios correntes da fundação, equivalentes a, no mínimo, um terço do total; (3) objetivos não lucrativos e que, por sua natureza, não possam ser satisfatoriamente executados por órgãos da administração federal, direta ou indireta; (4) demais requisitos estabelecidos na legislação pertinente a fundações. 
Chama-se empresa pública a entidade dotada de personalidade jurídica de direito privado, com patrimônio próprio e capital exclusivo da União, criada por lei para a exploração de atividade econômica que o governo seja levado a exercer por força de contingência ou de conveniência administrativa, podendo revestir-se de qualquer das formas admitidas em direito. Sua característica principal é possuir capital exclusivamente público, de uma só ou de várias entidades. Suas atividades se regem pelos preceitos comerciais.

Dá-se o nome de sociedade de economia mista à pessoa jurídica de direito privado, com participação do poder público e de particulares em seu capital e em sua administração, para realização de atividades econômicas ou serviço de interesse coletivo outorgado ou delegado pelo estado. Revestem a forma de empresas particulares, regendo-se pelas normas das sociedades mercantis, com as adaptações impostas pelas leis que autorizam sua formação.

São ainda características da sociedade de economia mista: (1) maioria das ações com direito a voto pertencente à União ou a entidade da administração indireta; (2) penhorabilidade dos respectivos bens; (3) regime tributário idêntico ao das empresas privadas; (4) foro comum, muito embora seja obrigatória a interveniência da União nas causas em que figurar como autora ou ré, o que torna a justiça federal competente para os feitos em que seja interessada; e (5) sujeição aos princípios e normas falimentares.

Administração estadual e municipal - No plano estadual, as funções executivas são exercidas pelo governador, auxiliado pelos titulares das diversas secretarias, enquanto as funções legislativas cabem às assembléias. Compete também ao estado dispor sobre a respectiva organização judiciária, ressalvada a competência das justiças federal, militar, eleitoral e do trabalho. Também ali podem ser criadas ou instituídas entidades de administração indireta.

O chefe do executivo municipal é o prefeito, cabendo as funções legislativas à Câmara Municipal, constituída de vereadores. Algumas prefeituras de capitais e cidades mais desenvolvidas dispõem de secretarias. Na maioria delas, porém, os diferentes assuntos (arrecadação de impostos, serviços públicos etc.) ficam a cargo de 
departamentos ou seções. Do mesmo modo que os estados, os municípios podem criar, ou instituir, entidades de administração indireta, já que a administração própria, no que respeita a seu particular interesse, é um dos postulados da autonomia municipal, assegurada pela constituição.

\subsection{Os princípios básicos da administração pública brasileira}

Segundo Medauar² (2000 apud DUARTE, 2004) os órgãos e entes da Administração direta e indireta na realização das atividades que lhes competem regem-se por normas além das normas específicas para cada matéria ou setor, há preceitos gerais que informam amplos campos de atuação. São os princípios do direito administrativo.

Segundo Duarte (2004), o termo princípio, teria sido usado primeiramente na Geometria, onde significava a verdade primeira. Princípios são as idéias fundamentais, os valores básicos da sociedade, com a função de assegurar a continuidade e a estabilidade da ordem jurídica e homogeneizar o sistema jurídico.

Os princípios são as idéias centrais de um sistema, ao qual dão um sentido lógico, harmonioso, racional, permitindo a compreensão de seu modo de organizar-se. A enunciação dos princípios de um sistema tem a utilidade de ajudar o ato de conhecimento do sistema jurídico que o ordenam e possuem caráter normativo, pois são usados para resolverem casos concretos. (PINHEIRO, 2004).

De acordo com Encyclopaedia Britannica do Brasil Publicações Ltda (2004), os princípios básicos da administração pública são quatro: legalidade, moralidade, impessoalidade e publicidade.

Pelo princípio da legalidade, o administrador público está, em toda a sua atividade funcional, sujeito aos mandamentos da lei e às exigências do bem comum, deles não podendo se afastar, sob pena de praticar ato inválido e se expor à responsabilidade disciplinar, civil e criminal.

${ }^{2}$ MEDAUAR, O. (2000). Direito Administrativo Moderno. Editora Revista dos Tribunais. 5 ${ }^{\text {a Ed. apud }}$ DUARTE, L.C. (2004). Direito Administrativo I. Capítulo 3 - Princípios da administração pública. Disponível em: <http://www.fada.adm.br/aprincipios.htm> Acesso em: 26 fev. 2004. 
A moralidade administrativa é entendida como o conjunto de regras de conduta tiradas da disciplina interior da administração. $\mathrm{O}$ ato administrativo terá que obedecer não somente à lei jurídica, mas à ética da própria instituição, impondo-se ao agente público para a sua conduta interna, segundo as exigências a que serve e a finalidade de sua ação que é sempre o bem comum.

O princípio da impessoalidade impõe ao administrador público a prática de atos para seu fim legal que a própria norma de direito indica como objetivo do ato. Dessa forma, fica o administrador proibido de buscar outros objetivos ou de praticar atos visando interesse próprio ou de terceiros.

Através da publicidade, divulga-se oficialmente o ato administrativo para conhecimento público e para indicar seus efeitos externos. A publicidade é requisito de eficácia e moralidade do ato administrativo.

De acordo com Duarte (2004), os princípios da Administração Pública são:

- Conforme Constituição Federal de 1988 - Art. 37 - A administração pública direta e indireta de qualquer dos Poderes da União, dos Estados, do Distrito Federal e dos Municípios obedecerá aos princípios de legalidade, impessoalidade, moralidade, publicidade e eficiência e também ao seguinte:

- Lei $n^{\circ}$ 9.784, de 29/01/99, que regula o processo administrativo no âmbito da Administração Pública Federal - Art. $2^{\circ}$ - A Administração Pública obedecerá, dentre outros, aos princípios da legalidade, finalidade, motivação, razoabilidade, proporcionalidade, moralidade, ampla defesa, contraditório, segurança jurídica, interesse público e eficiência.

O princípio da eficiência foi introduzido pela Emenda Constitucional 19/1998 e significa, que a Administração Pública e seus agentes deverão buscar o bem comum, por meio do exercício de suas competências de forma imparcial, neutra, transparente, participativa, eficaz, sem burocracia e sempre em busca da qualidade, primando pela 
adoção de critérios legais e morais necessários para melhor utilização possível dos recursos públicos, de maneira a evitar-se desperdícios e garantir-se uma maior rentabilidade social.

Ainda sobre o princípio da eficiência, Pinheiro (2004) diz que o artigo $2^{\circ}$ da Lei 9.874, que trata do processo administrativo no âmbito federal, também inseriu a eficiência como um dos princípios norteadores da Administração Pública, anexado aos da legalidade, da finalidade, da motivação, da razoabilidade, da proporcionalidade, da moralidade, da ampla defesa, do contraditório, da segurança jurídica e do interesse público.

Têm-se visto que os governos arraigados à burocracia gastam mal os recursos que arrecadam e têm grandes dificuldades para solucionar os problemas relativos à eficiência e eficácia das suas ações em benefício do cidadão-contribuinte, pois a prática indica que as forças negativas são superiores às forças propulsoras da modernidade.

O princípio da eficiência pouco tem sido objeto de estudo na doutrina brasileira. Representa inovação que merece sensível cuidado por tratar-se de importante instrumento para fazer exigir a qualidade dos serviços e produtos advindo do Estado. (PINHEIRO, 2004).

Meirelles $^{3}$ (1998 apud PINHEIRO, 2004) refere-se sobre a eficiência como um dos deveres da administração. Definiu-a como:

O que se impõe a todo agente público de realizar suas atribuições com presteza, perfeição e rendimento funcional. É o mais moderno princípio da função administrativa, que já não se contenta em ser desempenhada apenas com legalidade, exigindo resultados positivos para o serviço público e satisfatório atendimento das necessidades da comunidade e de seus membros.

O princípio apresenta dois aspectos, podendo tanto ser considerado em relação à forma de atuação do agente público, do qual se espera o melhor desempenho possível de suas atuações e atribuições, para lograr os resultados melhores, como também em relação ao modo racional de organizar, estruturar, disciplinar a Administração Pública.

${ }_{3}^{3}$ MEIRELLES, H. L. (1998). Direito administrativo brasileiro. São Paulo: Malheiros apud PINHEIRO, M. (2004). O princípio da eficiência na administração pública e o cidadão. Disponível em: <http://www.acmag.com.br/HTML/eficiencia.htm>. Acesso em 26 fev. 2004. 
De fato, almeja-se que os serviços públicos sejam realizados com adequação às necessidades da sociedade que contribui, de forma efetiva e incondicional, para a arrecadação das receitas públicas.

Muito se tem discutido sobre a qualidade das obras e serviços executados pelo poder público. A eficiência, pelo senso comum, deveria ser sempre fator determinante para atuação da máquina administrativa, mas a prática tem revelado inquinada dissonância. (PINHEIRO, 2004).

Eficiência aproxima-se da idéia de economicidade. Visa-se a atingir os objetivos, traduzidos por boa prestação de serviços, do modo mais simples, mais rápido, e mais econômico, elevando a relação custo/benefício do trabalho público.

O administrador deve sempre procurar a solução que melhor atenda ao interesse público do qual é curador. Mesmo sem estar explícito anteriormente, o princípio da eficiência estava presente na ordem político-jurídica, por ser conseqüência lógica do Estado de Direito organizado.

Segundo Pinheiro (2004), o princípio da eficiência é entendido como aquele que impõe à Administração Pública direta e indireta e a seus agentes a persecução do bem comum, por meio do exercício de suas competências de forma imparcial, neutra, transparente, participativa, eficaz, sem burocracia, e sempre em busca da qualidade, primando pela adoção dos critérios legais e morais necessários para a melhor utilização possível dos recursos públicos, de maneira a evitar desperdícios e garantir-se uma maior rentabilidade social.

\subsection{Gestão pública brasileira}

O quadro administrativo brasileiro é marcado por uma multiplicidade de situações, um modelo híbrido muito peculiar. Em primeiro lugar, a estrutura administrativa brasileira é influenciada por um lado, pelo Direito Administrativo ibérico e francês, o que resulta em uma rigidez organizacional maior — um maior engessamento, como se diz nos dias atuais. (ABRUCIO, 2004). 
Por outro ângulo, no entanto, a influência americana advinda do modelo presidencialista, que dá uma configuração peculiar ao organograma do Executivo, e sobretudo ao federalismo, que torna mais consorciativo o Estado brasileiro, resulta em um maior grau de flexibilidade e politização do nosso sistema administrativo.

O híbrido administrativo brasileiro também é formado pela convivência entre setores administrativos atrelados a uma burocracia meritocrática, outros nichos dominados pelo patrionialismo e cartorialismo (principalmente no nível subnacional e nos escalões mais baixos do Governo Federal), e ainda outra parcela do Estado que politiza o alto escalão do organograma estatal, podendo ou não levar em conta a racionalidade técnica. (ABRUCIO, 2004).

De acordo com a concepção tradicional, a melhor maneira de conduzir as atividades dos órgãos públicos consiste em estabelecer procedimentos que regulem sua atividade e uma série de limites e controles para prevenir abusos e faltas. Na melhor das hipóteses, deste modo se consegue evitar a corrupção e manter uma rotina de funcionamento que garanta o cumprimento das funções básicas, mas não de resultados específicos.

De acordo com Abrucio (2004), com base nesta situação, foram formuladas as estratégias vigentes sobre a modernização da gestão pública. No entanto, estas possuem objetivos e prioridades diferentes, centrados na busca de níveis mais elevados de eficiência e eficácia. Para atingir este objetivo, procura-se criar condições equivalentes à racionalidade das empresas privadas sem desconsiderar a especificidade do setor público. Neste não existem instrumentos contábeis equivalentes aos balanços anuais, nem indicadores claros de produtividade ou incentivos que a estimulem.

Segundo Tohá e Solari (2004), é comum, a falta de clareza a respeito dos objetivos e produtos de cada unidade administrativa ou prestadora de serviços. Portanto, para reproduzir a racionalidade microeconômica, devem ser definidos critérios e criados mecanismos que desempenhem este papel e que sejam coerentes com a realidade do setor público. 
Para atender a população deve-se conhecê-la, conhecer seus pontos de vista e levá-los em consideração. Está certo que as instituições públicas não têm o objetivo, como é o caso das privadas, de conquistar a clientela nem de retê-la. A relação é antes no sentido contrário: a administração pública é decorrente da sociedade, vive dos tributos dos cidadãos, independentemente do uso que cada um deles faz dos serviços públicos. (TOHÁ e SOLARI, 2004).

Durante os últimos anos, surgiram na América Latina múltiplos processos de mudança e inovação no campo estatal. Na maioria dos países da região o período de ajuste fiscal está sendo concluído e esta nova preocupação com o funcionamento do Estado já não se explica pela urgência de cortar gastos, senão pela ânsia de otimizar o uso dos recursos públicos e elevar a qualidade da ação do Estado.

Tohá e Solari (2004), afirmam que a maior transparência na administração é, ao mesmo tempo, uma forma de responder ao público e uma maneira de dinamizar os sistemas de controle, de baixo custo e alta eficácia política. Quando a informação é acessível e clara, quando as contas públicas são exigíveis, o controle dos cidadãos pode tornar-se mais efetivo e adequado que os controles estritamente administrativos. Na época em que a corrupção se transforma num mal tão difundido, esta pode ser uma estratégia para detê-la.

Portanto, não se trata somente de satisfazer os usuários ou de consultá-los, senão de transformar este vínculo num elemento-chave para a qualidade da gestão que contribua com informação sobre a qualidade dos serviços e estimule os esforços para melhorá-la. No nosso país, não existe uma cultura exigente e informada dos usuários que desempenha um papel de corretor da administração dos serviços. Criar esta cultura deve tornar parte do esforço atual de modernização do Estado e da nova gerência. (TOHÁ e SOLARI, 2004).

O Ministério do Planejamento, Orçamento e Gestão _ Secretaria de Gestão (2004) afirma que a sociedade organizada reconhece que tanto os desafios contextuais quanto as condições de funcionamento dos Estados — principalmente aqueles em desenvolvimento, exigem ações no sentido de se buscar seu fortalecimento institucional. 
No Brasil, os contextos político, econômico e social impõem transformações macro-institucionais que afetam o papel do Estado. Estas, por sua vez, exigem significativas transformações nas instituições públicas, em especial as do Poder Executivo Federal.

Dando continuidade, transparência e participação são princípios basilares da gestão democrática que permite ao cidadão se informar sobre a agenda proposta pelo governo e, por meio dos canais adequados, participar das decisões sobre assuntos relacionados ao interesse público e a seus legítimos interesses particulares.

Não só a administração deve passar por uma modernização, como também, os administradores do setor público, pois são eles que, desempenhando suas funções, praticam a prestação de serviços.

\subsection{Dirigentes e funcionários públicos}

A gerência pública passa a ser uma peça fundamental nesta nova forma de entender a modernização do Estado. Depois das tentativas mal sucedidas de reforma administrativa, hoje não mais se espera que as normas e os procedimentos garantam automaticamente a dinâmica institucional, mas que proporcionem o marco de referência para que as pessoas encarregadas da direção estabeleçam a referida dinâmica. Em outras palavras, trata-se de mudar o papel e o perfil dos dirigentes públicos, privilegiando neles suas capacidades gerenciais e de liderança.

Segundo Tohá e Solari, (2004), da condição de meros administradores dos organismos públicos passam a desempenhar um papel semelhante ao de gerentes, conduzindo as instituições como unidades produtivas ou prestadoras de serviços. Este conjunto de idéias foi difundido em vários países de todos os continentes, e tem sido aplicado não somente no âmbito restrito dos governos centrais e seus serviços, mas igualmente nos governos subnacionais e nos municípios. No âmbito dos poderes Judiciário e Legislativo, por sua vez, foram desenvolvidas concepções análogas, adaptadas à especificidade de cada um. 
A crítica contra o setor público afetou a imagem e o papel social dos funcionários. Ultimamente, no entanto, as tendências reformadoras atribuíram-lhes um papel cada vez mais atuante nas estratégias de mudança. Reconheceu-se que a forma de atuar das instituições públicas passa pela modificação das práticas e estilos de trabalho e pela preferência por estilos de gestão mais flexíveis, baseados na responsabilidade e na maior autonomia dos sujeitos. É reconhecido, por outro lado, que estas convicções teóricas não são postas sempre em prática com a determinação necessária.

Os funcionários públicos enfrentam críticas, expectativas e exigências de uma maneira bastante agressiva, reconhecendo nelas mais um perigo e um ataque do que uma oportunidade. No entanto, as sucessivas mudanças até o momento e no futuro representam, em termos mais amplos, mais um fortalecimento do que um desprezo ao papel dos servidores públicos. O ponto crítico surge no período de transição, quando são afetadas as garantias e comodidades do emprego público tradicional, sem ter, ainda, as oportunidades e desafios da nova etapa. (TOHÁ e SOLARI, 2004).

O tipo de gestão desejado atualmente requer funcionários mais qualificados, preparados para trabalhar em equipes e para enfrentar novas situações. Por isso, os processos de fortalecimento da gerência costumam ser acompanhados por um questionamento, às vezes, bastante drástico da função pública nos seus aspectos profissionais e de rotina de trabalho. Daí, decorrem as inimizades entre os novos gestores públicos e os funcionários, mas o próprio avanço deste conflito se encarregou de clarificar algumas coisas:

- Problemas de incorporação dos funcionários aos novos esquemas de trabalho não dependem principalmente de suas características pessoais, mas dos sistemas atuais de trabalho;

- Independentemente das virtudes dos gerentes, o conhecimento e a experiência dos funcionários são indispensáveis para o bom funcionamento dos organismos públicos;

- As possibilidades de mudança dentro das instituições públicas não devem partir de uma negação e um descrédito dos recursos humanos, mas pelo contrário, de uma valorização e atualização da sua função. (TOHÁ e SOLARI, 2004). 
Nos últimos tempos, a atenção começa a se deslocar do questionamento da cultura dos funcionários para a reestruturação da gestão dos recursos humanos. Atualmente, tornou-se um componente tão importante quanto à gestão estratégica ou a administração financeira, porém, diferentemente das anteriores, permanece muito mais vulnerável no que se refere à formação e sensibilidade dos profissionais que assumem este tipo de funções.

Hoje, torna-se cada vez mais importante a capacidade dos dirigentes públicos de gerenciar pessoal, em especial, de promover o trabalho em equipe, de abrir espaços para participação que contribui para a atividade da direção, de promover uma cultura organizacional que valorize o trabalho no setor público e as boas relações de trabalho no contexto da missão específica a ser cumprida. (TOHÁ e SOLARI, 2004).

O que se espera do funcionário público é que faça uma revisão do seu compromisso profissional e de trabalho. O cumprimento da lei e dos regulamentos e o respeito às hierarquias parecem ser atributos secundários em relação a outros mais relevantes: o profissionalismo, a responsabilidade, a autonomia, o espírito crítico, a abertura e a inovação, a preocupação com o público. O compromisso exigido é com o Estado (essencialmente, corresponderia a uma renovação da razão de ser do serviço público), com a democracia (a vontade coletiva e a cidadania como objetos principais da ação pública) e com a eficiência (o bom aproveitamento dos recursos, a procura da excelência e o aperfeiçoamento permanente). (TOHÁ e SOLARI, 2004).

As mudanças que sustentam este novo papel dos funcionários não são nada óbvias. É reconhecida a necessidade de aumentar os níveis de exigência na carreira pública e de estabelecer mecanismos para dispensar funcionários de desempenho insuficiente. Existe, no entanto, uma discussão em torno da seguinte questão: se o emprego público deve submeter-se às regras gerais do mercado de trabalho ou se deve manter uma especificidade na sua regulamentação.

A favor da primeira opção depõe a comprovada ineficácia dos tradicionais estatutos de trabalho no setor público que protegem a mediocridade e não oferecem nenhum tipo de estímulo ao bom desempenho. 
Os que defendem a opção de manter uma diferenciação para o setor público não negam a necessidade de mudanças nos atuais sistemas, mas sustentam a necessidade de uma proteção especial da estabilidade dos funcionários como uma forma de garantir sua independência e sua continuidade perante as autoridades políticas do período.

Além desta discussão, que se refere fundamentalmente aos sistemas de saída da administração, existe um consenso em relação à necessidade de ser muito mais seletivo e preciso no recrutamento e seleção de pessoal, o que representa também uma maneira efetiva de prevenir o problema anterior. Da mesma forma, reconhece-se a necessidade de incorporar nas carreiras, elementos meritocráticos de profissionalismo e competência. (TOHÁ e SOLARI, 2004).

\subsection{Propostas para mudanças na Administração Pública Brasileira}

O Ministério do Planejamento, Orçamento e Gestão_ Secretaria de Gestão (2004, grifo nosso), afirma que o atual quadro desafiador por qual passa a administração pública brasileira, requer uma estratégia de transformação da gestão pública, concebida e implementada de forma consensuada, com vistas à construção de um novo perfil de Estado:

No que tange à implementação, trata-se de proporcionar meios para que as organizações públicas tenham como foco os resultados. Isto requer:

- O ajuste das estratégias, mediante a redefinição de suas missões, de seus objetivos e de suas metas;

- O desenvolvimento de sistemas contínuos de monitoramento e avaliação de políticas, programas, projetos e desempenho institucional;

- A adequação das estruturas e modelos institucionais para agilizar o processo decisório e de ação, otimizar a comunicação, permitir o alcance de resultados e a eliminação de lacunas, paralelismos e sobreposições;

- A otimização dos processos de trabalho, adotando novos parâmetros de desempenho, regras mais flexíveis e incorporando inovações tecnológicas e gerenciais que permitam redimensionar, quantitativa e qualitativamente, os recursos humanos, orçamentários, financeiros e logísticos; 
- O aprimoramento do atendimento ao cidadão, mediante simplificação de processos, eliminação de exigências e controles desnecessários e facilitação do acesso aos serviços públicos;

- A adequação dos quadros funcionais, reestruturando carreiras e quadros de cargos, remunerando-os em níveis compatíveis com as responsabilidades e competências exigidas;

- O aprendizado contínuo e a efetiva gestão do conhecimento, mediante, principalmente, capacitação intensiva e permanente de servidores e dirigentes;

- Uma conduta ética e participativa pautada em elevados padrões de transparência e responsabilização; e

- $\quad$ aprimoramento de sistemas de informações, que contribuam para a melhoria da qualidade dos serviços e da agilidade decisória.

Tohá e Solari (2004, grifo nosso), por sua vez, propõem que dentre os critérios a serem considerados para que ocorram mudanças na administração pública, encontramse os conceitos da produtividade no setor público; a modificação dos processos orçamentários com definições ligadas a objetivos e produtos mensuráveis e passíveis de avaliação; a revisão dos elementos que definem a rentabilidade social dos programas, serviços e investimentos realizados pelo Estado; a incorporação de critérios que atribuem um peso maior à demanda dos usuários na tomada de decisão no setor público e, por último, a adoção de padrões comparativos como forma de avaliar o rendimento e a qualidade da ação estatal.

Os instrumentos concebidos para operacionalizar estes critérios incluem:

- a redefinição explícita da missão de cada órgão. Para adequar o funcionamento do órgão a sua missão, é desenvolvido o planejamento estratégico, estabelecemse objetivos e metas, definem-se atividades e programas, clientes e usuários, prioridades e prazos;

- definição de incentivos e sanções econômicas, profissionais e institucionais para obter comportamentos e interesses compatíveis com os objetivos definidos;

- avaliação dos resultados da gestão mediante indicadores, auditorias periódicas e diferentes estudos que incluem consultas ao público-usuário; 
- vinculação entre a avaliação da gestão e a designação de recursos orçamentários, a formulação de políticas e a nomeação, a confirmação ou o afastamento dos dirigentes.

Para Saxena, 2004, o cenário dos países em desenvolvimento está se tornando cada vez mais complexo, turbulento e dinâmico. Uma combinação de fatores externos e internos tais como o crescimento populacional, a infra-estrutura frágil, dívidas externas, relações internacionais assimétricas e a desigualdade social têm impedido o crescimento sócio-econômico destes países.

A necessidade de estruturação econômica tem levantado questões relativas ao papel do governo nas atividades econômicas, substituindo um perfil produtor de bens e serviços pela ênfase na criação de um ambiente econômico favorável ao crescimento. Para tanto, torna-se premente aumentar a eficácia e eficiência do governo. (SAXENA, 2004).

As transformações dos processos administrativos públicos, em andamento em vários países industrializados e pouco industrializados, tais com Austrália, Holanda, Inglaterra, Estados Unidos da América (EUA), Singapura etc. se refere a um programa integrado de mudança organizacional, com foco nos processos e não nas funções, visando melhoria de desempenho.

Processo é definido como um conjunto de atividades inter-relacionadas, caracterizado por demandas especificadas e tarefas de valores agregados, definidas para a produção de determinados resultados. Já a visão funcional tradicional de organizações otimiza funções individuais, algumas vezes às expensas do negócio como um todo.

O escopo restrito de uma função ataca sintomas do problema em uma função, mas deixa passar as causas enraizadas em outro. Também pode falhar na priorização de problemas que, embora pequena para qualquer função individual, pode ser ampla quando agregada. A nova proposta de transformação, portanto, está mais preocupada em refletir o que a organização faz do que o que ela é. Está voltada para o replanejamento, redesenho e implementação de processos administrativos, estrutura organizacional e 
suporte de sistema de informação em resposta às demandas externas, diretas e indiretas, perseguindo determinados objetivos. (SAXENA, 2004, grifo nosso).

Procura-se desenvolver uma arquitetura organizacional que vincula a estratégia da organização com os processos necessários à sua viabilização. Isto requer gerenciamento inovador e vontade de mudar.

Entretanto, as características da administração pública não favorecem tal transformação: é mais resistente à mudança, não é avaliada pela produção de resultados e cobrança de melhoria dos mesmos e não há promoção e reconhecimento baseado no mérito profissional, o que desestimula as iniciativas dos dirigentes que querem promover mudanças.

Assim sendo, segundo Saxena (2004, grifo nosso), "tal programa de transformação aplicado à Administração Pública, implica em uma reviravolta na forma como ela pensa e trabalha”. É um conceito global que se preocupa com quatro elementos:

1- Estratégia é a visão, as metas, os objetivos, o que é possível e desejável de se alcançar. A visão provê um alvo amplo para direcionar o planejamento; refere-se a uma força de direção na qual a organização se baseia para agir no seu ambiente e que deve ser publicamente expressa. A visão tem dois componentes - uma filosofia guia e uma imagem tangível e partilhável do propósito fundamental da organização, com o qual todos devem estar comprometidos;

2- Estrutura organizacional cujo objetivo é colocar o servidor mais próximo dos usuários, pois somente assim os servidores poderão ajudar a dar efetividade à mudança. Deve-se remover as resistências à mudança ouvindo e acatando idéias dos servidores sobre as melhorias dos processos, bem como delegar aos servidores o controle da qualidade do atendimento ao usuário. Quem tem a habilidade de melhorar os processos deve ter autoridade para fazê-los;

3- Tecnologia de informação com a qual a redução de gastos na administração pública realmente ocorre, pois este tipo de administração trabalha com grande 
volume de informação. Modernizar o sistema de compras, despesas e receitas propicia real eficácia nas operações governamentais;

4- Cultura organizacional é o padrão de crenças e expectativas partilhadas pelos membros da organização. Estas crenças e expectativas produzem regras de comportamento - normas - que fortemente moldam o comportamento dos indivíduos e grupos na organização. Quanto mais velha a cultura mais arraigadas as crenças e valores e mais difícil a mudança.

O sistema de autoridade, ordenado hierarquicamente, onde relações e interações são do tipo superior-subordinado, não dá, ao subordinado, o direito de fazer comentários nas práticas de trabalho dos superiores.

Para Saxena (2004), existem graus variados, para que a administração pública implante modificações:

- Melhoria de processo: Atua em parte do processo, refinando as tarefas que são realizadas, o que envolve redução de burocracia, de duplicação e do ciclo de tempo do processo, simplifica formas e reduz o número de rotinas excepcionais. Estas melhorias podem atingir 5-20\% em termos de custo, qualidade e tempo, mas raramente promovem impactos nos resultados da organização;

- Redesenho de Processo: significa um redesenho total de toda a extensão do processo e pode promover melhoria radical de processo (50\% ou mais). Tal redesenho requer análise do modelo de processo nos níveis altos da hierarquia da organização tal como pesquisa para identificar onde a tecnologia da informação pode ser usada para eliminar inteiramente algumas atividades do processo. Deve ser realizado quando há suporte dos dirigentes e quando o processo a ser redesenhado é crítico para o alcance dos objetivos da organização;

- Transformação organizacional: pretende mudar a estrutura e a cultura da organização para melhorar seus processos. Começa por definir a missão da organização e o que está tentando alcançar. A seguir, investiga como trabalha e como seus processos podem ser melhorados. 
Ainda, conforme Saxena (2004, grifo nosso), existem algumas fases a serem seguidas a fim de se promover uma modificação na Administração Publica:

- Fase 1 Clareamento e Visão - definição de estratégia e objetivos. Visão da organização no futuro partilhada por todos, o que vai mantê-los unidos em torno de uma identidade e sentido de destinos únicos;

- $\quad$ Fase 2 Conhecimento do processo - identificação dos processos organizacionais, seus objetivos e definição de seus limites, interfaces, principais inputs e outputs, departamentos que executam cada um destes processos, os usuários (internos e externos) que se beneficiam pelos mesmos e os fornecedores que produzem os inputs;

- Fase 3 Redesenho de processo - Agora deve se modelar os processos selecionados em detalhes, com uma representação gráfica dos mesmos. Será feita uma análise para apontar suas fraquezas e problemas, baseada na identificação e mensuração de seu desempenho, através de indicadores;

- Fase 4 Implementação do processo - nesta fase se operacionaliza o redesenho fazendo as necessárias mudanças na estrutura da organização, no sistema de informação e na cultura. Se as mudanças estruturais e culturais requeridas pelos novos processos são extensivas, esta fase passará por vários estágios;

- Fase 5 Avaliação de processo - o novo processo é permanentemente avaliado para assegurar que as deficiências sejam removidas.

\subsubsection{Dificuldades encontradas}

Saxena (2004) coloca ainda que: as grandes dificuldades do setor público são resultantes de algumas características:

- Muitas administrações públicas são direcionadas para os procedimentos e carecem de formulação explícita de estratégias/objetivos;

- Dificilmente a administração pública define quem é o usuário, já que tem o monopólio da prestação de determinados serviços e sua burocracia não está acostumada a ouvir o usuário; 
- Os benefícios são largamente derivados do pensar, organizar e agir horizontalmente, em termos de processos matriciais mais do que verticais. Assim é difícil para a administração pública perceber o conceito de processos organizacionais e mais ainda, de defini-los;

- Melhorar processos necessariamente significa definir seu alcance e medi-los. Como o conceito de processo é novo para a administração pública é difícil definir seu alcance em termos de indicadores apropriados que permitam mensuração.

Apesar dos riscos, o sucesso da transformação pode resultar em: melhoria radical em toda a organização; claridade de propósitos, direção, capacidades e missão real; alto grau de satisfação do usuário. Somente um número pequeno de organizações públicas, a maioria nos países industrializados, reconheceu a necessidade de reinventar a administração pública. (SAXENA, 2004).

\subsection{Considerações finais}

O presente capítulo pode ser sintetizado em três partes importantes para que se dê prosseguimento ao trabalho:

- $1^{\mathrm{a}}$ parte: dá origem e conceitua a Administração pública, em particular a Administração pública brasileira;

- $2^{a}$ parte: apresenta uma série de particularidades da administração pública brasileira identificando algumas dificuldades. Tais dificuldades apontam para uma mudança necessária e adequada aos tempos atuais.

- $\quad 3^{\mathrm{a}}$ parte: São apresentadas sugestões por alguns autores e pensadores do tema com a finalidade de melhoria na Administração/Gestão Pública.

Partindo das informações disponibilizadas, entende-se que, em decorrência de mudanças no contexto mundial, no tocante a aspectos econômicos, financeiros, sociais, etc., a administração pública é desafiada a adequar-se para que consiga sobreviver às dificuldades e apresentar resultados positivos de gestão. 
Nesta linha, pensadores e escritores do tema, sinalizam no sentido de indicarem ações que possam ser implantadas em busca da eficiência e eficácia dos serviços públicos, através de encaminhamentos que muito se assemelhem aos conceitos de Gestão do Conhecimento. Partindo desta constatação é que se julga necessário, neste trabalho, o aprofundamento nos conceitos e atividades da Gestão do Conhecimento.

Tal aprofundamento é apresentado no capítulo seguinte que, traz entre outros tópicos: o conceito de conhecimento, tipos de conhecimento, modos de conversão do conhecimento, conceito de Gestão do Conhecimento (GC), suas atividades, suas organizações, suas características no setor público e no Brasil.

A Gestão do Conhecimento é utilizada neste trabalho, como embasamento teórico e indicador de uma outra proposta que possa acrescentar, às tantas já realizadas, novos caminhos para a amenização de dificuldades no setor público utilizando-se de criatividade e demandando um custo quase zero de aplicação. 


\section{GESTÃO DO CONHECIMENTO(GC)}

\subsection{Considerações iniciais}

O presente capítulo traz o aprofundamento teórico sobre o conceito Gestão do Conhecimento(GC), neste trabalho, escolhido para defender uma proposta de mudança tão necessária a Administração Pública, como já explicitada no capítulo anterior por alguns escritores e estudiosos do tema.

De acordo com Andrade e Tomaz (2003) a difusão acelerada das novas tecnologias de informação e comunicação vem promovendo transformações na economia mundial e está na origem de um novo padrão de competitividade globalizado, onde a capacidade de gerar inovações em intervalos de tempo cada vez mais reduzidos torna-se vital para as empresas.

Neste cenário, observa-se um enxugamento das organizações, em busca do foco na sua especialidade, a formação de redes de empresas para atenderem mercados com alto nível de qualidade e velocidade e a crescente busca por profissionais qualificados, com requisitos aparentemente paradoxais como intuição, disciplina, flexibilidade, criatividade, etc.

Fala-se mesmo na constituição de uma nova era, ou paradigma, ou sociedade, ou economia ou revolução, onde palavras como informação, conhecimento, ambiente, intangível, conectividade passam a superar em espaço e importância outras, até então imbatíveis, como produtividade, capital, matéria-prima, mão-de-obra ou chão de fábrica. 
Nessa perspectiva, se o fator de produção da economia agrícola foi a terra, o da economia industrial foi o capital, o da economia de serviços e economia global foi o trabalho, o da economia digital é o conhecimento. (ANDRADE e TOMAZ, 2003).

A humanidade já realiza a Gestão do Conhecimento (GC) há milênios e nenhuma empresa sobrevive sem algum tipo de GC. Mudanças muito recentes, no entanto, na capacidade de comunicação e processamento de informações e o exponencial crescimento da importância da capacidade inovadora para o desempenho econômico, tornaram a GC uma preocupação deliberada, sistemática e metódica em muitas organizações privadas, governamentais e públicas de maneira geral. Neste sentido, a diferença entre a prática da GC e a prática corrente de gestão tradicional nas organizações é tão grande que diz-se se tratar de uma revolução e não de uma evolução do processo de gestão. (TERRA, 2003 a).

Nos últimos anos, a Gestão do Conhecimento (GC) emergiu como um dos temas mais importantes na bibliografia sobre gestão empresarial. Já são vários os cursos de nível de pós-graduação tratando do tema, e muitas empresas, inclusive no Brasil, começam a criar cargos do tipo "gerente de GC" e as empresas de software já têm também vários aplicativos desenvolvidos especificamente para a GC. Esse importante movimento e soluções, entretanto, está em sua forma mais visível, limitado às necessidades e condições da grande empresa. (KRUGLIANSKAS e TERRA, 2003).

O recurso conhecimento, como jamais na história, está desempenhando um papel preponderante para o desenvolvimento econômico-social de uma nação. Ao contrário de outros recursos (capital, trabalho, recursos naturais), o recurso conhecimento pode ser alta e rapidamente transferível através do tecido produtivo e social a um custo marginal de produção muito baixo, o que o torna, de maneira amplamente comprovada, o recurso mais rentável quando bem alavancado e explorado.

Ele se encontra em sua forma mais preciosa na cabeça das pessoas, mas também, transformado e explicitado em documentos, conteúdos não estruturados, processos, patentes e melhores práticas documentadas. Organizações e países que compreendem bem a importância deste recurso tanto do ponto de vista econômico como social, trazem a gestão do mesmo para o pano de frente de suas políticas gerenciais. (TERRA, 2003 a). 
Na empresa, a Gestão do Conhecimento pode ser vista como um processo análogo ao de Qualidade Total. Nesse sentido, as empresas estão começando a se preocupar com o conhecimento tácito transformando-o em explícito em todos os seus processos do negócio.

Estimativas indicam que, nos próximos anos, as empresas irão gastar mais com a Gestão do Conhecimento (consultoria, serviço, softwares, produtos, etc.) do que com Qualidade ou Reengenharia. (TEIXEIRA FILHO, 1999).

\subsection{Evolução administrativa e tecnológica}

Com a evolução das técnicas de Gestão, passa-se por organizações da Sociedade Industrial, baseadas nos conceitos de Taylor, Fayol e Max Weber, que estabelecem, de forma clara, as regras de uma organização piramidal hierárquica: ter sempre alguém em nível superior para orientar as tarefas a serem executadas. (MYERS, 1996).

A partir da execução da tecnologia, são desenvolvidas novas idéias em relação à Gestão das organizações. Inicialmente ensaiam-se modelos orientados para processos e projetos, como as estruturas matriciais, voltadas a resultado. Mas, com a intensificação do uso da tecnologia de informação e a automação dos processos, o homem, tido como uma engrenagem no processo produtivo das organizações, deixa esta função para as máquinas e passa a exercer funções mais relevantes e, portanto, voltadas para a análise e inovação.

A Sociedade da Informação é iniciada nos anos 60 com a revolução da informática, avança posteriormente para outras funções em que a rotina estava presente ousando, até mesmo, a avançar em espaços supostamente específicos para a atuação da mente humana, ou seja, sistemas baseados em inteligência artificial e em uma série de regras e definições transmitidas por diversos especialistas. (RODRIGUEZ,1995).

Com a evolução da tecnologia e das técnicas de gestão, surge na década de 70 a gestão pela Qualidade Total, que busca a otimização dos processos e melhoria do 
desempenho, mas com o objetivo de só competir com um mercado cada vez mais exigente e com novas técnicas baseadas em Just-in-time, Time to Market, Visão Estratégica, Inovação e Imagem. (RODRIGUEZ, 1995).

Juntamente com o processo de reengenharia vêm os conceitos de downsizing e eliminação de níveis hierárquicos reduzindo assim o número de níveis gerenciais intermediários e os empregados de base.

A resultante de todo esse tumulto foi o corte sistemático de verbas e de pessoal em empresas de todo o mundo, com maior reflexo para empregados de multinacionais. A idéia seria reinventar, reestruturar a organização - a mola da economia moderna - para o processo principal de atendimento ao cliente. (RODRIGUEZ, 1995).

Na década de 80 , surgem os microcomputadores e, com eles, um mercado ignorado pelas grandes empresas de informática na época, que explodiu na revolução da informação, dando forma e espaço à Sociedade do Conhecimento, atrelada a valores intangíveis e de difícil quantificação, e com a evolução do homem e da sua tecnologia, passa a ser o diferencial competitivo das organizações, já que fabricar e comprar a tecnologia disponível não é mais o diferencial, a partir do momento que todos podem tê-la. (RODRIGUEZ, 1995).

Os anos 90 presenciam uma mudança de paradigma no campo da administração a partir do surgimento de novas formas de corporações, que incluem parcerias estratégicas e redes organizacionais. $\mathrm{O}$ acirramento da concorrência, os rápidos avanços da tecnologia de informação e, principalmente, a globalização da economia atuam como catalisadores do desenho de um novo ambiente de negócios.

No final do século XIX, linhas telegráficas são estendidas por todo o território norte-americano. Antes do rádio, da televisão e da internet, nasce aí o conceito de informação compartilhada.

Prosperam as primeiras agências de notícias, fornecendo conteúdo editorial atualizado a preços compatíveis, independentemente da localização geográfica do veículo; surgem os primeiros jornais com alcance nacional, que são impressos em cidades diferentes, com as mesmas notícias, aproveitando a existência de jornais que 
vivem de adquirir espaços em jornais de todo o país a preços descontados para revendêlos a empresas com presença nacional: são os embriões das primeiras agências de propaganda. Em outra vertente, graças às altas necessidades de investimentos das estradas de ferro, o mercado de capitais começa a adquirir o perfil que tem hoje. (GUTIERREZ, 1999).

Essa passagem histórica marca o momento em que o capital, enquanto elemento essencial à geração de riqueza, começa a ceder espaço à informação e ao conhecimento.

A percepção dessa realidade leva as empresas a procurarem uma forma de sistematizar o ativo representado pelas habilidades e experiências acumuladas. A esse conjunto de técnicas é dado o nome de Knowledge Management (KM), ou, em português, Gestão do Conhecimento, que utiliza como principal ferramenta para sua implementação a Tecnologia da Informação (TI). (GUTIERREZ, 1999).

Para Santos et al. (2003) o contexto histórico diz respeito ao fato de que as novas práticas de gestão empresarial, surgidas principalmente a partir dos anos 70, são decorrentes ou provocadas por mudanças macro-ambientais que tornaram obsoletas as práticas até anteriormente utilizadas. Ocorre, assim, uma quebra de paradigma que precisa ser avaliada do ponto de vista da evolução dos novos modos de se administrar uma organização.

$\operatorname{Toffler}^{4}$ (1980 apud SILVA, 2003), de forma figurativa afirma que a civilização tem evoluído ao longo de três grandes ondas de transformação: a Revolução Agrícola (Primeira Onda), a Revolução Industrial (Segunda Onda) e a Revolução dos Serviços

(Terceira Onda). Trata-se dos grandes momentos históricos de evolução da sociedade humana, cada qual com seus paradigmas próprios relacionados aos aspectos político, econômico, social, tecnológico e organizacional. Este último estágio representa a era do conhecimento, da informação, ou ainda, a sociedade do conhecimento.

\footnotetext{
${ }^{4}$ TOFFLER, A. (1980). A terceira Onda. Rio de janeiro: Record apud SILVA, C. M. (2003). A gestão do conhecimento: estudo de caso em uma empresa fabricante de móveis rústicos. $117 \mathrm{p}$. Dissertação (Mestrado) - Escola de Engenharia de São Carlos, Universidade de São Paulo, São Carlos. 2003.
} 
O CENÁRIO AMBIENTAL DA EVOLUÇÃO DOS MODELOS DE GESTÃO

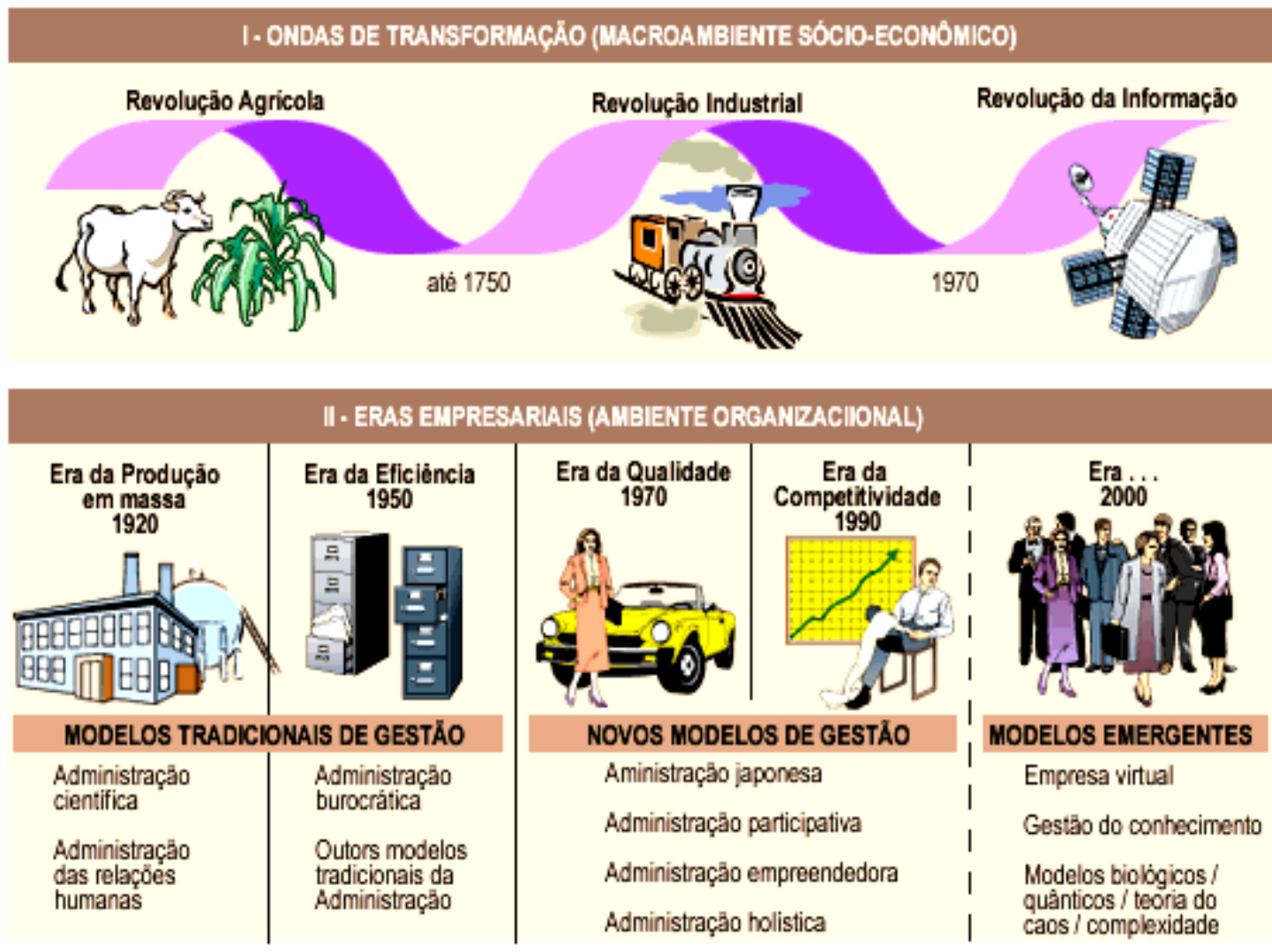

Figura 01 - Fonte: Santos, et al.(2001)

\subsection{Conhecimento}

Conhecimento pode ser definido como: estado ideal do dado e informação combinando experiência, julgamento, intuição, crenças e valores. Um sistema vivo que cresce e se modifica, interagindo com o ambiente (MELLACI et al., 1999).

Nesse aspecto, vale diferenciar e compreender os conceitos que formam a sua base. Segundo Colmanetti (2003) os dados, as informações e o conhecimento, na linguagem coloquial, são geralmente tratados como sinônimos, porém, um exame das definições mostra a seqüência da evolução dos conceitos.

Santos et al. (2003) diz que, para compreender Gestão do Conhecimento, devese iniciar descrevendo os conceitos de dado, informação, conhecimento, chegando por fim, ao processo de Gestão do Conhecimento. 
Dado pode ter significados distintos, dependendo do contexto no qual a palavra é utilizada. Para uma organização, dado é o registro estruturado de transações. Genericamente, pode ser definido como um "conjunto de fatos distintos e objetivos, relativos a eventos" (DAVENPORT \& PRUSAK, 1998, p. 2). É informação bruta, descrição exata de algo ou de algum evento. Os dados em si não são dotados de relevância, propósito e significado, mas são importantes porque são definidos como a matéria-prima essencial para a criação da informação.

Informação é uma mensagem com dados que fazem diferença, podendo ser audível ou visível, e onde existe um emitente e um receptor. É o insumo mais importante da produção humana. "São dados interpretados, dotados de relevância e propósito" (DRUCKER, 1999, p.32). É um fluxo de mensagens, um produto capaz de gerar conhecimento. É um meio ou material necessário para extrair e construir o conhecimento. Afeta o conhecimento acrescentando-lhe algo ou reestruturando-o.

O conhecimento deriva da informação assim como esta, dos dados. O conhecimento não é puro nem simples, mas é uma mistura de elementos; é fluido e formalmente estruturado; é intuitivo e, portanto, difícil de ser colocado em palavras ou de ser plenamente entendido em termos lógicos. Ele existe dentro das pessoas e por isso é complexo e imprevisível. NONAKA e TAKEUSHI (1997, p. 63) observam que "o conhecimento, diferentemente da informação, refere-se a crenças e compromissos”.

Para Takashina (1999), conhecimento é o estado cognitivo além da característica ou atributo. Implica desenvolvimento e entendimento ativo e habilidade de estender o nível de compreensão para reunir contingências da vida.

Conhecimento é uma mistura fluida de experiência condensada, valores, informação contextual e insight experimentado, a qual proporciona uma estrutura para a avaliação e incorporação de novas experiências e informações. Ele tem origem e é aplicado na mente dos conhecedores. Nas organizações, ele costuma estar embutido não só em documentos ou repositórios, mas também em rotinas, processos, práticas e normas organizacionais. (DAVENPORT e PRUSAK, 1998, p.6) 


\subsubsection{Tipos de conhecimento}

Podem ser encontrados na literatura consultada, basicamente os tipos de conhecimentos: tácito e explícito.

O Conhecimento tácito é extremamente pessoal sendo guardado pelo próprio trabalhador e está estritamente vinculado com a experiência, técnica e ferramentas próprias. Não se encontra escrito, existe uma quase completa falta de documentos sobre ele e quase nenhuma base para multiplicá-lo de forma estruturada. (MIRSHAWKA, 1998).

O conhecimento tácito capacita os funcionários de uma empresa a se adaptar rapidamente para responder de maneira adequada e flexível às exigências de um produto ou serviço único ou não previsto. Quanto maior é o seu nível total numa empresa tanto maior é a facilidade da organização para responder às demandas do mercado.

Ao contrário do que ocorre com o conhecimento tácito que reside na intuição, no bom senso e na aptidão pessoal, o conhecimento articulado é explícito e passível de repetição. O conhecimento articulado pode ser descrito em etapas e ações. Não está apenas na cabeça das pessoas, encontra-se documentado e codificado para que os serviços possam ser realizados de forma precisa. (MIRSHAWKA, 1998).

Para Nonaka e Takeuchi (1997), a distinção entre conhecimento explícito e conhecimento tácito é a chave para a compreensão das diferenças entre as abordagens ocidental e japonesa ao conhecimento. O conhecimento explícito pode ser facilmente processado por um computador, transmitido eletronicamente ou armazenado em bancos de dados. No entanto, a natureza subjetiva e intuitiva do conhecimento tácito dificulta o processamento ou a transmissão do conhecimento adquirido por qualquer método sistemático ou lógico. 


\subsubsection{Modos de conversão do conhecimento}

Nonaka e Takeuchi (1997) defendem quatro modos de conversão para a criação do conhecimento aos quais dão o nome de socialização, externalização, combinação e internalização.

- A socialização (do conhecimento tácito em conhecimento tácito) caracteriza-se pela observação, imitação e prática que proporcionam a um indivíduo adquirir conhecimento tácito diretamente de outro sem que precise usar a linguagem;

- A externalização (do conhecimento tácito em conhecimento explícito) quando o conhecimento tácito é expresso na forma de metáforas, analogias, conceitos, hipóteses ou modelos provocados pelo diálogo ou pela reflexão coletiva. A externalização é a chave para a criação do conhecimento;

- A combinação (do conhecimento explícito em conhecimento explícito) dá-se quando os indivíduos ao trocarem e combinarem conhecimentos através de meios como documentos, reuniões, conversas ao telefone ou redes de comunicação computadorizadas, reconfiguram estas informações através de classificação, do acréscimo, da combinação e da categorização do conhecimento explícito levando a novos conhecimentos;

- A internalização (do conhecimento explícito em conhecimento tácito) está intimamente ligada ao aprender fazendo, quando conhecimentos são internalizados sob a forma de modelos mentais ou know-how técnico compartilhado.

Estes quatro modos de conversão do conhecimento criam o que Nonaka e Takeuchi, (1997) denominam de espiral do conhecimento que, por sua vez, dão origem a novos tipos de conhecimento (figura 02, p.52). 


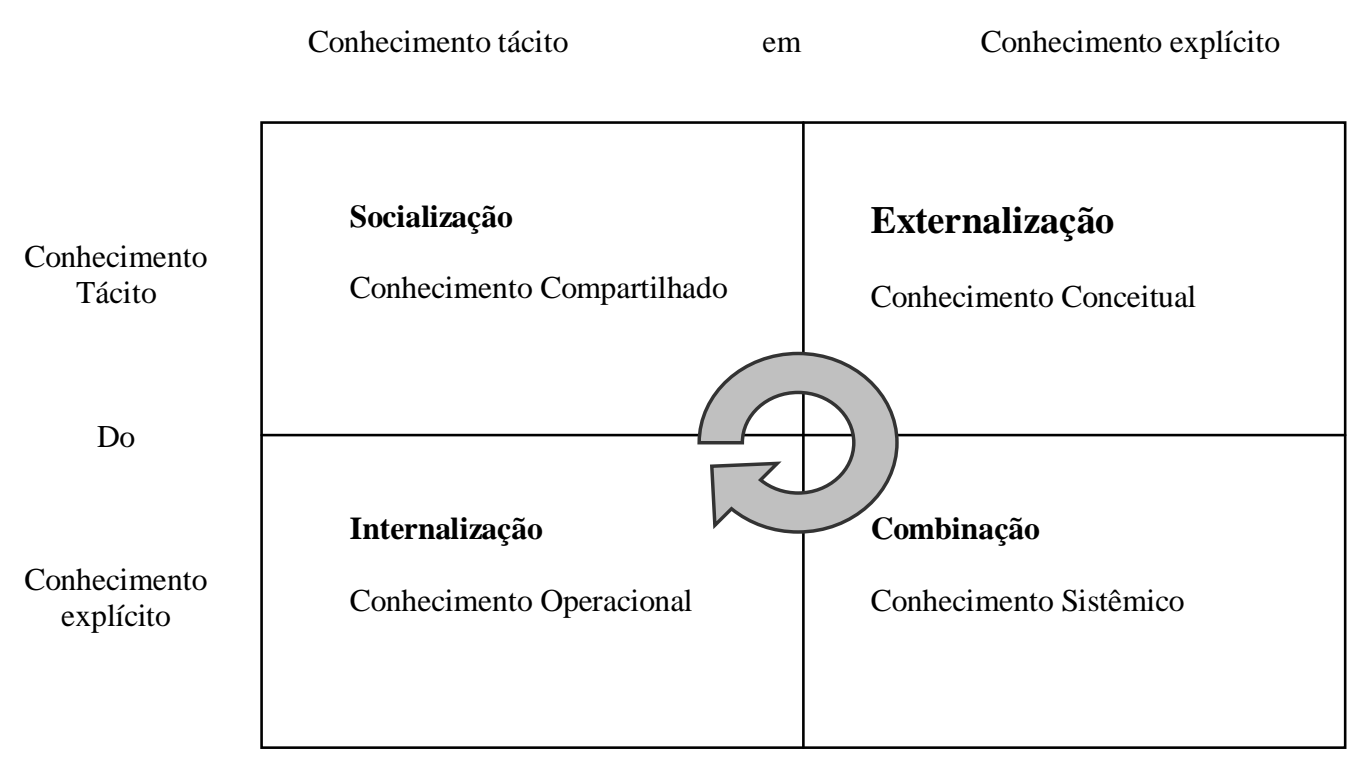

Figura 02 - Conteúdo do conhecimento criado pelos quatro modos de conversão Fonte: Nonaka e Takeuchi, (1997, p. 81).

\subsection{Conceito de gestão do conhecimento (GC)}

O tema Gestão do Conhecimento (GC) tem bases sólidas em várias abordagens distintas e complementares. (KRUGLIANSKAS e TERRA, 2003).

São diversos os focos de estudo - ciências econômicas, administração geral, aplicações de informática, gestão da inovação, organização do trabalho, engenharia de produção, psicologia etc. - cujas conclusões se superpõem, se complementam e, às vezes, se contrapõem.

É fato, também, que a GC trouxe novo ferramental conceitual, gerencial e de informática que enriquece as conclusões de trabalhos anteriores relacionados a essas várias disciplinas. A GC sintetiza de forma bastante interessante conclusões dos vários campos anteriormente mencionados, permitindo aos gestores tratar melhor a principal matéria-prima que garante a diferenciação e a competitividade: o Conhecimento. (KRUGLIANSKAS e TERRA, 2003).

Nesta linha, ainda segundo os autores, a Gestão do Conhecimento implica na coordenação sistêmica de esforços em vários planos: organizacional e individual; estratégico e operacional; normas formais e informais que discutam várias dimensões: 
- O papel da alta administração;

- Novas práticas de organização do trabalho;

- Desenvolvimento de processos específicos para facilitar as atividades da GC;

- Práticas e políticas de administração de recursos humanos;

- Novas tecnologias de informação e comunicação;

- Novas formas de medir resultados empresariais e

- Novas formas de aprendizado com o ambiente.

O principal ativo das empresas refere-se ao ser humano, seja ele colaborador, cliente, fornecedor ou parceiro. Escutar cada uma das partes, entender suas idéias, criar ambientes que favoreçam a criação e a transformação do conhecimento, as trocas de experiências, o compartilhamento do êxito e também do erro, levam a um ganho significativo nos resultados das organizações. Em outras palavras, a grande riqueza das empresas, sobretudo as das que lidam com Tecnologia de Informação (TI), está em seu próprio interior, nas pessoas que emprestam seu conhecimento a elas. É só investigá-las, e investir em seu aperfeiçoamento.

Caberá às empresas decidirem-se por capturar o capital intelectual, o capital do conhecimento. Ao gerenciamento desse tipo de capital, dá-se o nome de Gestão do Conhecimento Organizacional. (GATTONI, 1999).

Há duas linhas principais de pensamento na Gestão do Conhecimento, a oriunda das técnicas de modelagem de dados advoga que existe conhecimento explícito e implícito (tácito). O primeiro baseia-se no aprendizado formal e organizado, relativamente fácil de mensurar através de testes. Está contido em documentos, projetos, livros, etc. O conhecimento implícito (tácito) está relacionado ao conceito de modelo mental. Este é a combinação de conhecimento sobre o tópico, tática a ser empregada para resolver a questão, gostos pessoais, etc. É difícil de capturar e modelar, pois abrange a maneira como se aborda um problema. É esse como, que se denomina heurística.

A segunda linha de pensamento origina-se da ciência da administração. Essa linha propõe que sejam criados núcleos de conhecimento que dêem origem, em um 
processo evolutivo, a repositórios ou bases de conhecimento. Esses núcleos seriam críticos para a sobrevivência das organizações. Seria possível priorizar os esforços de modelagem de conhecimento, eliminando aqueles que não representassem relação direta com os fatores de sucesso.

O conhecimento contido nas mentes e nos processos da organização pode ser definido, organizado, compartilhado e enriquecido e, portanto, as relações de causa e efeito dentro da cadeia organizacional são percebidas e atendidas de forma mais eficaz.

A Gestão do Conhecimento passa, essencialmente, pelo compartilhamento dos conhecimentos individuais para a formação do conhecimento organizacional, sendo assim, a pessoa que detém o conhecimento é que decide se compartilha ou não. Depende, portanto, do quanto está motivada para isso. Motivação é, dessa forma, uma questão chave para uma bem sucedida Gestão do Conhecimento. (SERAFIM FILHO, 1999).

Com algumas variações de um autor para outro, a gestão do Conhecimento refere-se a todo esforço sistemático realizado pela organização para criar, utilizar, reter e medir o seu conhecimento.

Para Terra (2003a), Gestão do Conhecimento significa organizar as principais políticas, processos e ferramentas gerenciais e tecnológicas à luz de uma melhor compreensão dos processos de geração, identificação, validação, disseminação, compartilhamento e uso dos conhecimentos estratégicos para gerar resultados econômicos para a empresa e benefícios para os colaboradores.

Gestão do Conhecimento é todo o esforço sistemático realizado pela organização para identificar, capturar, compartilhar, obter, criar, organizar, utilizar, melhorar, reter e medir o seu conhecimento. É uma estratégia que transforma ativos intangíveis - informação armazenada e talentos de seus membros - em produtividade, valor e aumento de competitividade. Ensina corporações, de gerentes a empregados, a produzir e otimizar habilidades como uma entidade coletiva. (ANDRADE e TOMAZ, 2003, p.112). 


\subsubsection{Atividades da gestão do conhecimento}

A gestão do conhecimento pode ser apresentada através de 4 (quatro) etapas ou atividades a serem desenvolvidas:

- Geração do conhecimento, corresponde à fase embrionária do saber. O uso e o estímulo de faculdades como a criatividade e a intuição humana, aliados às práticas da pesquisa, do estudo e da experimentação, caracterizam todo esse momento;

- Codificação do conhecimento, através da organização das idéias, valendo-se de linguagens e meios que seriam para registrar o que foi desenvolvido (livros, artigos ou mesmo artefatos que tenham o conhecimento embutido);

- Disseminação do conhecimento, cujo objetivo é a distribuição e divulgação de saber por inúmeros recursos de comunicação hoje disponíveis (conversas informais, cursos, intranet, internet, reuniões, programas, etc.);

- Apropriação do conhecimento, que, no caso das pessoas, se dá pelo aprendizado e efetiva utilização. Nas empresas, esta fase ocorre, por exemplo, através de patentes, registro de marcas, etc. (MELLACI et al., 1999).

\subsection{Organizações da gestão do conhecimento}

A abordagem da Gestão do Conhecimento nas organizações tem tido ênfase no compartilhamento de conhecimentos e na formação de memória organizacional, principalmente visando captar, reter e disseminar o conhecimento tácito nas organizações. (LAPA, 2003).

Há anos, pouco se lê e ouve sobre a importância do conhecimento nas organizações. No início da década de 90, fala-se muito pouco de gestão do conhecimento e afins, afinal as empresas estão terminando suas dores de downsizing e reengenharia estando voltadas para seus programas de qualidade total. (LAPA, 2003).

Na segunda metade da década de 90 já começam a ter mais referências sobre os temas gestão de conhecimento, capital intelectual, inteligência competitiva. Em 1998 tem-se um recorde de bibliografias sobre o tema conhecimento. A questão do 
tratamento dos ativos intangíveis parece que começa a ser melhor discutida deste ponto para cá e, hoje nos parece, se não está resolvida, está bem encaminhada.

Vê-se em muitos artigos e livros relatos sobre como gerar vantagem competitiva através do uso intensivo de conhecimento nos processos de negócio e nos processos produtivos. Tal conhecimento já teria sido internalizado pelas organizações. (LAPA, 2003).

O momento das empresas brasileiras exige cada vez mais a melhoria na capacidade de obter resultados através das pessoas. Investimentos em tecnologias de última geração, inovação nas metodologias de trabalho ou melhoria nos processos podem ser realizados por toda e qualquer empresa, mas se as pessoas que fazem a organização andar não estiverem sendo capacitadas, não adiantará muito o esforço. Montar um banco de talentos internos através da identificação de potenciais tem sido um belíssimo exemplo de como começar a realizar gestão do conhecimento: a idéia é conhecer o que o colaborador conhece! Empresas como Eletrobrás, Ericsson e Siemens realizam atividades similares há bastante tempo. (LAPA, 2003).

Ainda segundo Lapa (2003) dentre as iniciativas mais praticadas pelas organizações no sentido de prática da Gestão do Conhecimento temos: o Mapeamento de processos. Existem alguns passos para preparar uma empresa no sentido de receber iniciativas e estratégias de gestão do conhecimento, mas talvez o mapeamento dos processos seja o alicerce. Uma empresa precisa conhecer como funciona. A organização precisa ter bem mapeadas suas operações, seus negócios e suas atividades.

Diversas outras iniciativas vêm sendo implantadas em empresas no Brasil de maneira crescente, o que aponta um crescimento representativo da utilização e aperfeiçoamento de conceitos de gestão do conhecimento. Os portais corporativos, por exemplo, têm sido amplamente utilizados. Mesmo que muitos websites corporativos sejam chamados indevidamente de portais corporativos, estas empresas já estão caminhando neste sentido.

Uma organização aprende à medida que seus indivíduos aprendem, tornando seus conhecimentos tácitos em explícitos e, principalmente, quando tudo isso é 
compartilhado. Se a informação é poder, então é imprescindível estimular as pessoas a compartilharem os seus conhecimentos.

Capturar o saber é mais do que desenvolver bases de dados e indexar

documentos. É, sobretudo, construir ligações, conexões entre indivíduos. Sem este contexto comum, uma efetiva partilha do saber nunca ocorrerá dentro da empresa. É este conhecimento tácito, que cada um de nós acumulou ao longo de dezenas de milhar de experiências pessoais, que as organizações têm de captar para ganharem uma vantagem competitiva sustentável no mercado. (GEUS, 1999).

Numa organização do conhecimento, a conversação entre as pessoas é trabalho sério, é talvez a forma mais importante de trabalhar. (PRUSAK, 1998).

A Organização da Era do Conhecimento é aquela que aprende através das pessoas. Aquela que aplica o conhecimento ao conhecimento já existente com a finalidade de evoluir buscando assim, maior produtividade voltada aos interesses das pessoas e da sociedade.

Nesta produtividade deve estar inserido o conceito de valor. Só devem ser produzidos bens ou serviços que agreguem valor às pessoas, pois são elas que avaliam tal produção tanto quanto profissionais envolvidos no processo produtivo como consumidores. (GEUS, 1999).

\subsection{A Gestão do conhecimento no setor público}

De acordo com o Instituto de Políticas Públicas Florestan Fernandes (2004), a bibliografia sobre Gestão do conhecimento do setor público é escassa, mesmo fora do Brasil. A falta de referencial específico traz algumas limitações para a sua discussão. Entretanto, é um tema de primeira ordem já que o conhecimento se tornou fator básico de criação de valor e não se distribui espontaneamente entre os diversos agentes, especialmente no caso de instituições governamentais. 
É uma constatação óbvia: o conhecimento mantido em sua própria dinâmica não se espalha, seja em uma empresa, em uma comunidade ou na sociedade ou no governo, e tende a ter uma difusão desigual e mantenedora de privilégios.

Numa sociedade onde conhecimento e informação são elementos de manutenção de poder e de exclusão social, o tema é de fundamental importância para a construção de parâmetros mais democráticos e justos de organização social.

Podemos dizer de três esferas de tratamento dessa questão:

- Gestão do conhecimento na esfera privada - Aplicada à esfera privada, às empresas, é o modelo mais difundido e corresponde à visão que se tem contemporaneamente do tema;

- Gestão pública do conhecimento - reconhece que o conhecimento deve ser tratado como bem público e trata de como se faz a disseminação do conhecimento, de forma pública e democrática. Deve assegurar que o conhecimento não seja motivo de estratificação econômica, social, política e cultural perversa e que seja, sim, um fator de diminuição das desigualdades;

- Gestão do conhecimento no setor público - agrega aspectos das duas esferas anteriores, porém é muito específico. É a questão onde se tem menor produção teórica. Trata da produção, manutenção e distribuição do conhecimento nos organismos governamentais, fundamental para a democratização, eficiência e racionalidade dos processos político administrativos.

A gestão do conhecimento, se colocada de forma genérica, não dá conta dessa especificidade do setor público. É preciso definir seu referencial teórico, sua terminologia, de que maneira os conceitos podem auxiliar a identificar as melhores práticas já existentes e de que forma a gestão do conhecimento pode estimular, racionalizar e democratizar o processo de gestão de políticas públicas.

Numa sociedade onde o conhecimento se tornou fator básico de estratificação econômica, social, política e cultural, o conhecimento deve ser visto como um capital primordial. Os agentes que apresentam maior capacidade de retê-lo, obtê-lo, produzi-lo e utilizá-lo ocupam as posições hegemônicas na sociedade, nas instâncias 
governamentais ou no poder político. (INSTITUTO DE POLÍTICAS PÚBLICAS FLORESTAN FERNANDES, 2004).

É preciso considerar que cada organização tem um conceito de gestão de conhecimento diferente. Boas administrações e bons dirigentes públicos sabem que, além de bons resultados, é preciso produzir e circular informação.

Quando se trata de gestão do conhecimento na área pública, o objetivo principal não é disputar o mercado (objetivo da gestão do conhecimento na esfera privada), mas pensar como o Estado pode registrar, usar e disseminar o conhecimento acumulado e produzido, para atender melhor a sociedade e garantir direitos de cidadania. O foco está, assim, na socialização e democratização do conhecimento e na construção de uma inteligência pública e coletiva.

Teixeira Filho e Oliveira (2001) apresentam colocações sobre a preparação do Brasil para a Sociedade do Conhecimento já que estamos em um processo histórico de transformação em três níveis: no individual, no organizacional e no social.

A preocupação está em identificar qual seria a responsabilidade do poder público diante deste novo desafio, pois principalmente na década de 70, o milagre econômico brasileiro deu-se em decorrência principalmente pela atuação de grandes estruturas públicas como a Eletrobrás, Petrobrás, Sistema Telebrás, etc. A educação também recebeu investimentos por parte de organizações públicas que montaram escolas para a formação de seu quadro de pessoal.

Nos anos 90, ainda segundo os autores, em decorrência de informações veiculadas nos meios de comunicação caracterizando o setor público e seus profissionais como caros e ineficientes, houve por parte dos governantes a chamada modernização do país através da privatização de muitas empresas estatais.

De acordo com Teixeira Filho e Oliveira (2001), as organizações públicas estão em falta de muita coisa: falta memória organizacional, faltam processos de qualidade e gerenciamento, falta cultura de atendimento a clientes, falta até mesmo autoconfiança e 
esperança no futuro, principalmente entre os níveis hierárquicos inferiores. Mas, por outro lado, há uma enorme riqueza em conhecimento tácito, em verdadeiros portais humanos. Há um número enorme de especialistas muito bem formados e com décadas de experiência. Um dos principais desafios, inclusive, para muitas dessas organizações é explicitar e compartilhar todo esse conhecimento, antes que essas pessoas se aposentem ou morram. Porque além de tudo, a maioria das organizações públicas tem equipes envelhecidas e não tem recebido novos talentos a muito tempo.

O tema da Gestão do Conhecimento no espaço público transcende as organizações públicas, e entra pelo espaço da cidadania na Sociedade do Conhecimento, indo tocar na questão da inclusão digital, a qual, ainda segundo Teixeira Filho e Oliveira (2001), tem sido desenvolvida através de algumas iniciativas: Programa Acessa São Paulo na cidade de São Paulo; o Programa de Disseminação de Estatísticas do Trabalho pelo Ministério do Trabalho e Emprego; o Portal Minas - Prodemge, a Internet Comunitária, Internet Sênior e Janelas para a Cidadania em Minas Gerais; Biblioteca Digital Brasileira.

Para Finger e Brand (2001) organizações do setor público não são qualitativamente diferentes das organizações do setor privado, mas elas operam em um ambiente mais difícil, que tornam seu funcionamento e administração, mais complexos. Por motivos históricos as organizações do setor público são também, mais burocráticas do que as do setor privado. Sendo, portanto um desafio às pessoas que pretendem colocar o conceito de Organização de Aprendizagem numa prática gerencial.

O que causa a necessidade de investimentos no setor público quanto às Sociedades do Conhecimento, ou seja, a implantação da Gestão do Conhecimento, são as pressões externas e internas sofridas pelo mesmo. No primeiro caso, existe um tipo de concorrência entre cidades e Estados quanto à aquisição de novas indústrias geradoras de impostos. O que buscam essas indústrias? Mão-de-obra qualificada, locais que ofereçam qualidade de vida aos seus moradores, capacidade de crescimento dos recursos necessários, etc. Já no aspecto interno, existe o interesse político em conseguir reconhecimento pela capacidade de administrar de criar e inovar no sentido de prestar serviços de qualidade, fazendo isso de maneira eficiente e eficaz, para que existam recursos a serem aplicados para sanar as necessidades externas. 


\subsection{A gestão do conhecimento no Brasil}

Segundo Terra (2003 a) os conceitos de Gestão do Conhecimento, aliados às típicas ferramentas de gestão e estratégica empresarial, poderão trazer enormes benefícios para o Brasil se aplicados para a realização de políticas públicas. No setor empresarial a gestão do Conhecimento normalmente envolve alguns objetivos:

- Obtenção de vantagens competitivas a partir do foco no desenvolvimento de competências-chave em áreas de alto potencial e atratividade;

- Incentivo à colaboração entre pessoas que normalmente não colaborariam;

- Reutilização de melhores práticas e disseminação de conhecimentos consolidados.

Ao contrário de políticas industriais tradicionais a aplicação da Gestão do Conhecimento no plano nacional envolve um foco muito maior na variável conhecimento, nos ativos intangíveis setoriais e na obtenção, desenvolvimento e disseminação de informações e conteúdos estratégicos.

Ainda segundo Terra (2003 a), sabe-se da complexidade não apenas conceitual, mas também institucional envolvida na implementação de programas de Gestão do Conhecimento em um plano nacional.

Experiências bem sucedidas de implementação de GC requerem lideranças altamente motivadas, envolvidas e dispostas a romper com padrões tradicionais de gestão de sistemas de informação e gestão de pessoas. Quando bem implementados, porém, programas de GC podem se tornar uma ferramenta competitiva de grande impacto.

Para Santos et al. (2003) nas últimas três décadas, as organizações brasileiras, tanto privadas como públicas, de forma crescente passaram a se conscientizar da importância da revisão dos seus modelos de gestão: no caso das empresas privadas, a motivação era a sua sobrevivência e competitividade no mercado; no caso das empresas públicas, tal motivação era a sua capacidade de cumprir sua missão, ou seja, atender com qualidade a prestação de serviços de interesse da sociedade. 
Ao mesmo tempo, focando a realidade empresarial brasileira, constata-se que as organizações nacionais, tanto públicas como privadas, já desenvolvem esforços no sentido de recuperar o tempo perdido (de pelo menos duas décadas) que levou a um atraso em relação à situação mundial. No entanto, se há poucas empresas brasileiras consideradas de "classe mundial", já é possível avaliar a partir destas a aplicabilidade das novas práticas gerenciais que garantirão a sua sobrevivência num mercado cada vez mais globalizado e competitivo. (SANTOS et al., 2003).

Este contexto gerou um esforço, às vezes de forma frenética, de busca de novos modelos de gestão empresarial. De outro lado, à medida que novas idéias e práticas gerenciais surgiam, eram apresentadas, pelos seus proponentes (geralmente empresas de consultoria empresarial) como a solução dos desafios gerenciais e, eventualmente, recebidas pelo meio acadêmico e empresarial como modismos. Assim, idéias e práticas novas, como Qualidade Total, Reengenharia, Gestão Participativa, Terceirização e Alianças Estratégicas, entre outras, precisaram contar com o tempo para ficar claro que as organizações adequam os seus modelos de gestão muito mais por um processo de evolução contínua do que por rompimento ou substituição dos conhecimentos gerenciais. (SANTOS et al., 2003).

Neste sentido, para identificar e avaliar as características peculiares às novas práticas de gestão empresarial, hoje dispersas na literatura e nas pesquisas acadêmicas na área de Administração, é preciso analisá-las dentro do contexto histórico de sua evolução e de sua relação com o conjunto de outras práticas gerenciais.

No Brasil, para se transformar as empresas em, empresas que aprendem, serão necessárias profundas revisões nos valores das lideranças empresariais nacionais. Esse é o primeiro passo, e talvez o mais importante. (SANTOS et al. 2003).

Para Andrade e Tomaz (2003) a grande maioria das empresas brasileiras não está estruturada por processos, não se preocupa com padronização e nunca se preocupou com o desenvolvimento de metodologias para treinamento eficazes, o que dificulta bastante o acesso ao conhecimento e a sua disseminação. 
Em estudo comparativo - Brasil x Estados Unidos - realizado por Damiani (2001) são apresentados os resultados de pesquisa sobre gestão do conhecimento, realizada entre 1999 e 2000, que abrange as 500 maiores empresas brasileiras segundo a revista Exame e as 500 maiores empresas americanas segundo a revista Fortune. Os resultados refletem a atitude dos administradores frente à gestão do conhecimento, assim como as expectativas e as barreiras que permeiam a implementação desses projetos.

Damiani (2001) afirma que as pesquisas de campo indicam que este tema não é considerado um modismo passageiro, pois de acordo com a percepção da grande maioria dos respondentes ( $81 \%$ dos brasileiros e $92 \%$ dos americanos) a Gestão do Conhecimento é importante para o futuro dos negócios; $50 \%$ dos brasileiros e $88 \%$ dos americanos respondentes apontam a melhoria na transferência de conhecimento por toda a empresa como o principal objetivo atingido. A cultura da empresa aparece como principal barreira para $44 \%$ dos brasileiros e $38 \%$ dos americanos das empresas respondentes.

\subsection{Considerações finais}

O presente capítulo busca situar o leitor sobre os principais conceitos defendidos sobre Gestão do Conhecimento (GC), sendo que este resultado de pesquisa bibliográfica não pretende esgotar os assuntos aqui tratados.

A Gestão do Conhecimento (TERRA, 2003b) atualmente encontra similaridades com outros tipos de definições e pontos de vistas: Patrimônios de conhecimento (SVEIBY, 1998); Capital Intelectual (EDVINSSON e MALONE, 1998); Criação de conhecimento na empresa (NONAKA e TAKEUCHI, 1997); Conhecimento Intelectual (DAVENPORT e PRUSAK, 1998); Aprendizagem organizacional e organização de aprendizagem (ROESCH, 2001).

A valorização do conhecimento existente nos indivíduos que, por sua vez, encontramse num ambiente organizacional, tem sido muito difundida nos meios organizacionais e acadêmicos. Isto talvez pelo fato de que, a partir do momento que a organização propicia um ambiente de crescimento intelectual para seus profissionais, tem como resultado uma maior flexibilidade através de inovação e criatividade necessárias ao momento de turbulência nas 
quais se encontram, possibilitando inclusive, o ganho competitivo que a maioria das organizações movidas pela lucratividade almejam.

No setor público como foi apresentado neste capítulo, existe a escassez de inúmeros recursos e, a aplicação do Conceito de Gestão do Conhecimento pode ser uma possibilidade de resgate ao importante papel que este tipo de organização precisa desempenhar na realidade brasileira.

Apropriando-se deste conceito serão utilizadas as etapas apresentadas no item 3.4 .1 (p.55) para a proposição de um método de aplicabilidade/ prática da Gestão do Conhecimento no Setor Público a ser apresentado no capítulo seguinte:

\begin{tabular}{|c|c|c|}
\hline $\begin{array}{l}\text { Atividades da } \\
\text { Gestão do } \\
\text { Conhecimento }\end{array}$ & No que consiste & $\begin{array}{l}\text { Modos de conversão do } \\
\text { conheicmento }\end{array}$ \\
\hline Geração & $\begin{array}{l}\text { Criar/ adquirir/ localizar conhecimentos nos } \\
\text { processos da organização }\end{array}$ & \\
\hline Codificação & $\begin{array}{l}\text { Organizar / armazenar conhecimento existente e } \\
\text { utilizado na execução dos processos }\end{array}$ & - Socialização \\
\hline Disseminação & $\begin{array}{l}\text { Distribuir / compartilhar conhecimentos certos } \\
\text { para as pessoas certas. }\end{array}$ & - Externalização \\
\hline Apropriação & $\begin{array}{l}\text { Os envolvidos são capazes de fornecer } \\
\text { conhecimento relevante, no momento adequado, } \\
\text { de forma pró-ativa e de acordo com seu perfil. }\end{array}$ & $\begin{array}{l}\text { - } \text { Combinação } \\
\text { - Internalização }\end{array}$ \\
\hline
\end{tabular}

Figura 03 _ Etapas da Gestão do Conhecimento.

Andrade e Tomaz (2003) afirmam que a escassez de livros publicados sobre gestão do conhecimento é notória e os poucos que existem ficam, em geral, num plano, ou muito genérico ou muito fragmentado, apresentando alguns modelos, dicas, casos e métodos sem introduzir uma metodologia consistente para facilitar a gestão do conhecimento integrada a conceitos, modelos e casos práticos coerente, funcional e adaptada à realidade brasileira. 
Esta afirmação reforça o principal objetivo deste trabalho que é o de Propor um método de trabalho que, utilizando como referencial os modelos da Enterprise Knowledge Development (EKD), desenvolva-os através das atividades da Gestão do Conhecimento, utilizando informações do setor de alimentação escolar do município de São Carlos, SP.

A metodologia Enterprise Knowledge Development (EKD), foi apresentada pela primeira vez no Brasil, em 2001, através de um dos componentes do grupo de pesquisa ao qual a autora faz parte, no Departamento de Engenharia de Produção da Escola de Engenharia de São Carlos, Universidade de São Paulo. Outros trabalhos, buscando sua maior compreensão, foram realizados e caberá a este, explorar sua relação com a Gestão do Conhecimento.

Embora existam especificidades neste trabalho, acredita-se na sua utilidade como fio condutor de experiências similares a fim de se adquirir segurança e buscar soluções personalizadas sem gastar muito dinheiro, desenvolvendo seu próprio projeto de gestão do conhecimento e, mais tarde, transformando-o no sistema de gestão da empresa.

A idéia é superar problemas, lançando mão das vantagens decorrentes de aspectos culturais de nosso país, como, por exemplo, a criatividade, flexibilidade e sociabilidade do povo brasileiro. (Andrade e Tomaz, 2003).

No capítulo seguinte, será apresentada de forma sucinta a metodologia a ser utilizada: Enterprise Knowledge Development (EKD). 


\section{ENTERPRISE KNOWLEDGE DEVELOPMENT (EKD)}

\subsection{Considerações iniciais}

A finalidade deste capítulo é proporcionar ao leitor um referencial de consulta aos conceitos envolvidos pela metodologia de modelagem organizacional: Enterprise Knowledge Development (EKD), pois esta será utilizada e analisada a fim de identificar possibilidades para a prática da Gestão do Conhecimento através da proposição de um método de trabalho.

A escolha desta metodologia, dentre outras existentes para a modelagem organizacional, justifica-se pelo fato de que esta tem sido explorada de diferentes maneiras pelo grupo de pesquisa ao qual esta autora faz parte.

A correlação entre a Gestão do Conhecimento e a metodologia escolhida é trabalho inédito e como já fora afirmado anteriormente, acredita-se na sua utilidade como fio condutor de experiências similares a fim de se adquirir segurança e buscar soluções personalizadas, desenvolvendo um projeto próprio de gestão do conhecimento e, mais tarde, transformando-o no sistema de gestão da empresa.

As fontes de informação consultadas baseiam-se em artigos disponíveis em < www.dsv.su.se/ js/ekd_user_guide.html >, BUBENKO et al. (2001) e dissertações de mestrado de PÁDUA, S. (2001) e PÁDUA, F. (2003). Por não ser o objetivo desta autora, a apresentação detalhada desta metodologia, mas sim a sua utilização como referencial para a aplicação da Gestão do Conhecimento, seus conceitos serão apresentados superficialmente. 
A modelagem organizacional iniciou-se nos anos 80 pelo projeto Plandata e foi refinado pelo Swedish Institute for Systems Development (SISU) no final dos anos 80. A idéia de modelo de negócio do SISU era estendida para o modelo organizacional e mais tarde desenvolvida no projeto ESPRIT ELKD sendo aplicada no projeto ESPRIT ELEKTRA (Electrical Enterprise Knowledge for Transforming Applications), sua estrutura de modelagem é denominada Enterprise Knowledge Development (EKD). (PÁDUA, 2001).

O projeto ELEKTRA visa principalmente a aplicação do método EKD para problemas de gerenciamento de mudanças dentro de organizações da Grécia e Suécia, gerando um conjunto de práticas genéricas de forma a aplicá-las em outras companhias.

\begin{abstract}
As descrições estruturadas, resultantes da aplicação da metodologia Enterprise Knowledge Development (EKD), permitem a realização de diferentes tipos de análises e discussões sobre o que tem sido dito e escrito sobre a organização. Esses modelos podem ser efetivamente usados para representar e discutir como projetar e melhorar processos organizacionais, e como desenvolver estratégias futuras. (PÁDUA, 2001, p.69).
\end{abstract}

Segundo Kirikova ${ }^{5}$ (2000 apud PÁDUA, 2001) a metodologia Enterprise Knowledge Development (EKD) pode ser utilizada em situações diferentes com propósitos diferentes. Neste trabalho, está sendo utilizada no gerenciamento de conhecimento organizacional ou aprendizagem organizacional para formar a base de propagação e ampliação de conhecimentos num setor da administração pública, a fim de buscar o controle tão necessário neste tipo de gestão.

Com sua utilização espera-se propor um método que venha ao encontro das necessidades encontradas na Administração Pública apresentadas no Capítulo I deste trabalho, como também, atender grande parte das propostas realizadas por autores indiretos do tema Gestão do Conhecimento também apresentadas no mesmo Capítulo, desta vez sinalizando para algumas etapas a serem seguidas de forma prática.

\footnotetext{
${ }^{5}$ KIRIKOVA, M. (2000) Explanatory capability of enterprise models. Data \& Knowledge Engineering, n.33, p.119-136 apud PÁDUA, S. I. D. (2001). Investigação do processo de desenvolvimento de software a partir da modelagem organizacional, enfatizando regras do negócio. 144p. Dissertação (Mestrado) Escola de Engenharia de São Carlos, Universidade de São Paulo, São Carlos. 2001.
} 
O referencial a ser utilizado para a prática do método a ser apresentado, neste momento, é o Setor de Alimentação Escolar do Município de São Carlos, responsável pela execução do Programa Nacional de Alimentação Escolar (Apêndice_A). Sua aplicação não será realizada neste trabalho pelo tempo restrito ao mesmo, mas poderá servir de norteador a trabalhos futuros.

\subsection{Aplicação da metodologia EKD}

A modelagem dos processos organizacionais envolvendo a missão, objetivos da organização, as tarefas que os atores executam para completar suas obrigações na organização; como essas tarefas agem cooperativamente a fim de atingir os objetivos; quais os recursos necessários a essas atividades e quais regras impõem os processos organizacionais, são temas relacionados ao método a ser proposto.

Para Bubenko et al. (2001), a metodologia EKD não se constitui de apenas um produto: o Modelo Organizacional e seus submodelos. O sucesso de sua aplicação envolve a maneira como a mesma é introduzida e conduzida dentro da organização. Alguns dos resultados obtidos a partir de experiências na aplicação da Modelagem Organizacional na Suécia são:

- Descrições claras e com rigor adicional;

- Uma evolução na aprendizagem organizacional;

- Aceitabilidade na realização de mudanças e no processo de reengenharia da organização.

Pádua (2001) apresenta um conjunto de pré-condições necessárias à aplicação da metodologia EKD na organização:

- Os envolvidos na modelagem deverão ter uma visão clara da missão da organização, alocar tempo e recursos necessários ao processo de modelagem, ser originários de todos os setores da organização, procurando agrupar todos os conhecimentos necessários ao negócio e possuírem autoridade para reprojetar a organização; 
- As atividades de modelagem deverão considerar as questões a serem discutidas, quem serão os participantes, suas tarefas e qual tempo será utilizado;

- Devem ser realizadas entrevistas com os envolvidos, pois esta possibilita uma visão melhorada das pessoas que participam nas sessões de modelagem e de suas visões, problemas, esperanças, preconceitos e sentimentos;

- O primeiro seminário para modelagem deverá ser organizado de maneira a garantir o trabalho concentrado numa atmosfera mais tranqüila e sem interrupções;

- Com informações decorrentes do primeiro seminário é preciso estruturar e analisar o resultado, tornando-o apresentável para a próxima sessão;

- Novo seminário faz-se necessário para a retomada das fases anteriores e avaliação do modelo resultante que deverá apresentar todas as modificações e suas respectivas justificativas.

\subsection{Modelo Organizacional}

$\mathrm{Na}$ metodologia EKD, seus componentes são modelos conceituais que examinam a organização e seus requisitos de um número de perspectivas interrelacionadas. Esses modelos são abstrações do mundo físico. Para uma dada organização, esses modelos irão constituir coletivamente o Modelo Organizacional. (ROLLAND ${ }^{6}$ et al., 2000 apud PÁDUA, F., 2003).

O modelo organizacional envolve um número de submodelos inter-relacionados (figura 05, p.70), onde cada um representa algum aspecto da organização. São eles:

1. Modelo de Objetivos (MO): representa o que a organização e os empregados querem alcançar; descreve e discute a razão e a motivação dos componentes de um documento de requisitos;

\footnotetext{
${ }^{6}$ ROLLAND et al., (2000). A decision making pattern for guiding the enterprise knowledge development process. Journal of Information and Software Technology, v.42, p.313-331. apud PÁDUA, F. S.M. (2003). A importãncia da técnica de modelagem organizacional EKD no desenvoovimento de diagramas Use Case. 130 p. Dissertação (Mestrado) - Escola de Engenharia de São Carlos, Universidade de São Paulo, São Carlos. 2003.
} 
2. Modelo de Regras do Negócio (MRN): é usado para proporcionar a operacionalização ou limitar os objetivos devendo ser formuladas de modo a serem consistentes com o Modelo de Objetivos;

3. Modelo de Conceitos (MC): representa a definição de coisas e fenômenos relacionados a outros modelos;

4. Modelo de Processos do Negócio (MPN): define processos organizacionais, suas interações e como manuseiam a informação e materiais. Em geral são similares aos tradicionais modelos de diagramas de fluxo de dados (DFD);

5. Modelo de Atores e Recursos (MAR): descreve os relacionamentos de atores e recursos com componentes do Modelo de objetivos e Modelo de Processo do Negócio;

6. Modelo de requisitos e Componentes Técnicos (MRCT): é uma tentativa inicial de se definir toda a estrutura e propriedades do sistema de informação para apoiar as atividades do negócio, como definido no MPN. (PÁDUA, 2001, p76-78).

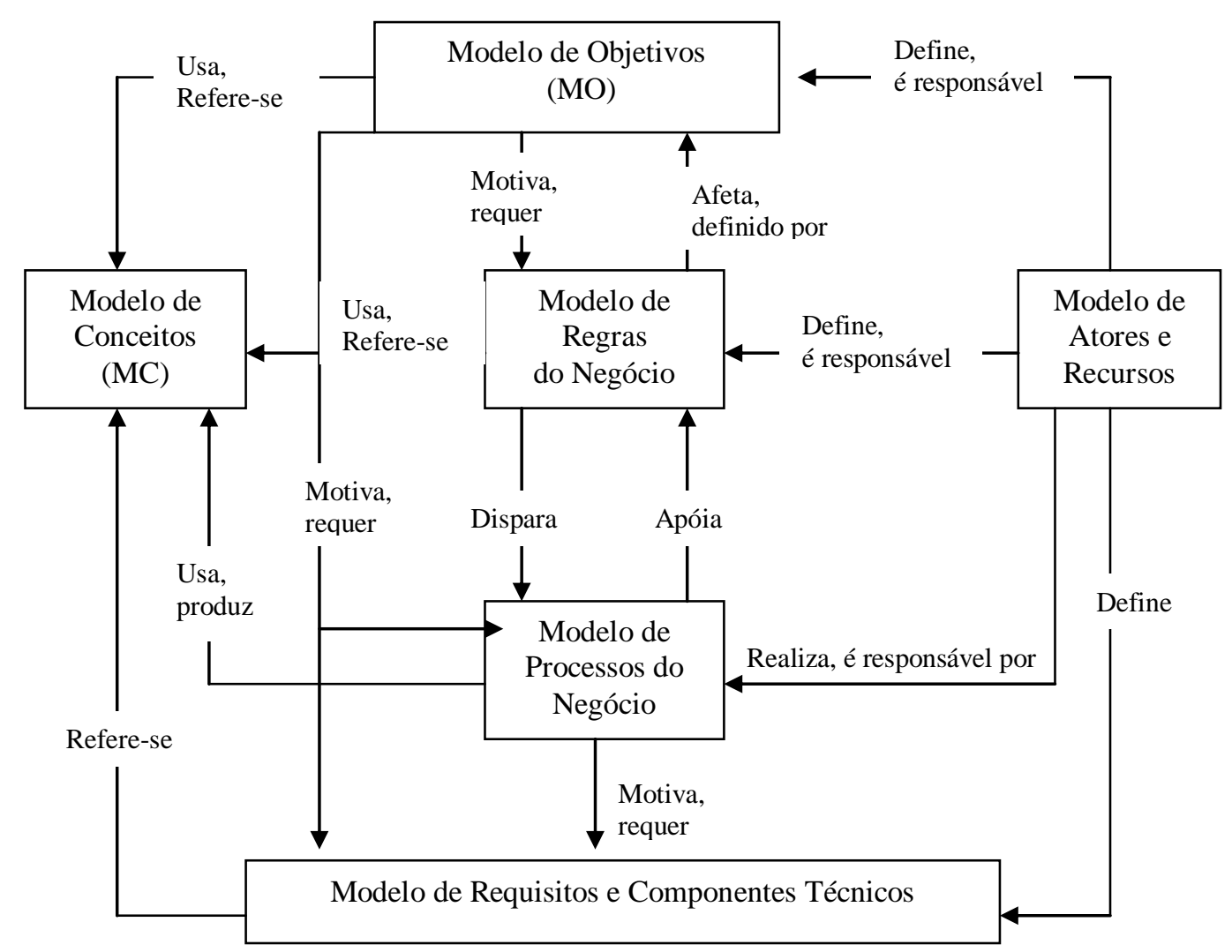

Figura 04 - Submodelos que compõem o Modelo Organizacional. Fonte: BUBENKO et al. (1998) apud PÁDUA (2001, p.80) 


\subsubsection{Modelo de Objetivos (MO)}

O Modelo de Objetivos é um sub-modelo do Modelo Organizacional usado para descrever os objetivos da organização e todas as questões associadas para atingi-los. Os componentes do modelo de objetivos são: objetivo, problema, causa, restrição e oportunidade.

- O objetivo do negócio é o estado desejado do negócio a ser atingido. Os objetivos podem ter valores opcionais de prioridade e criticabilidade (com possíveis valores: alto, médio, baixo) permitindo às pessoas que estão modelando, fixar diferentes níveis de prioridade;

- O problema é usado para expressar que o ambiente está ou pode ficar em um estado não desejado que, dificulte alcançar os objetivos. Problemas podem ser: ponto fraco - fatores que podem reduzir a possibilidade de alcançar um objetivo e, ameaça - quando a empresa não possui conhecimento para reduzir o efeito de problemas;

- A causa expressa explicações ou razões para os problemas. Situações ou estados fora do controle do projeto, processo ou da organização;

- A restrição expressa leis, regras, ou políticas do mundo externo afetando componentes e ligações com o Modelo Organizacional;

- Uma oportunidade é usada para expressar recursos que colaborem para o alcance de objetivos. Situações em que se deseja obter vantagens. BUBENKO et al. ${ }^{7}$ (1998 apud PÁDUA, 2001).

Existem ligações dentro do Modelo de Objetivos (MO), (figura 06, p. 72), que são:

- Relacionamento de apoio usado para refinar ou decompor objetivos e outros componentes. É essencialmente vertical. A decomposição de objetivos utiliza relacionamento do tipo AND/OR, sendo AND utilizado para demonstrar que

\footnotetext{
${ }^{7}$ BUBENKO et al. (1998). EKD user guide, Dpt of computer and systems sciences. Stockholm, Royal Institute of Technology apud PÁDUA, S. I. D. (2001). Investigação do processo de desenvolvimento de software a partir da modelagem organizacional, enfatizando regras do negócio. 144p. Dissertação (Mestrado) - Escola de Engenharia de São Carlos, Universidade de São Paulo, São Carlos. 2001.
} 
para se atingir o objetivo principal é necessário antes atingir os que o precedem (sub-objetivos). O refinamento OR apresenta sub-objetivos alternativos, para se para atingir o objetivo principal é necessário atingir antes, apenas um dos subobjetivos apresentados;

- Relacionamento de impedimento que mostra influências negativas entre componentes do Modelo de Objetivos;

- Relacionamento de conflito onde situações mostram que ao se alcançar um objetivo haverá um conflito com outro.

Os objetivos devem ter sentenças completas para evitar ambigüidades ou incertezas. Deve-se evitar palavras com muitos significados e palavras que possam ser mal entendidas.

Existem dois textos associados a cada componete: short name usado para numerar e identificar os componentes do modelo que deve ser único para servir de referência e long name usado para expressar e armazenar a descrição do componente.

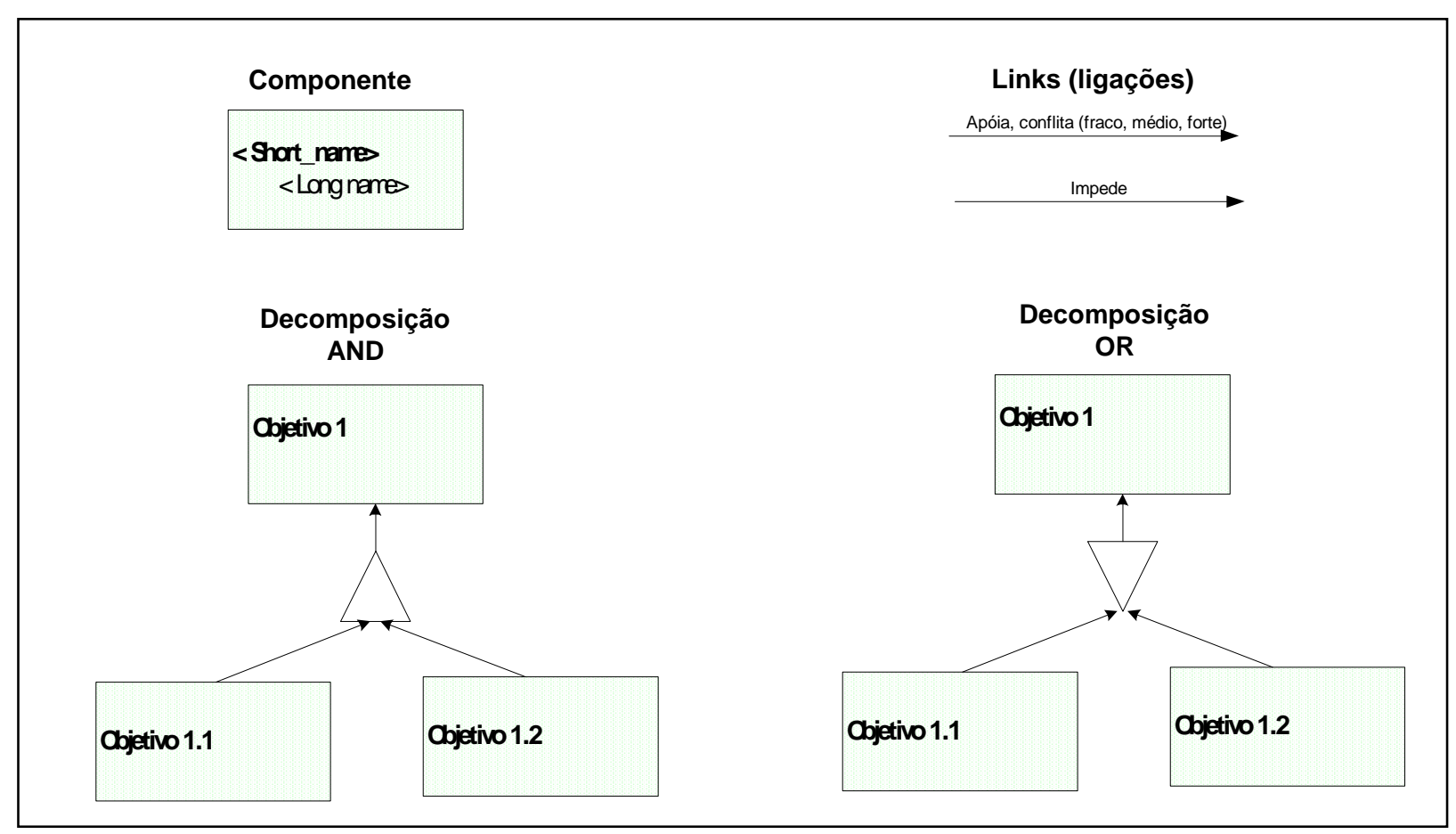

Figura 05 - Notações do Modelo de Objetivos (MO).

Fonte: Bubenko et al. ${ }^{3}$ (1998 apud PÁDUA, 2001, p.84). 


\subsubsection{Modelo de Regras do Negócio (MRN)}

O Modelo de Regras do Negócio sendo sub-modelo do Modelo Organizacional é usado para definir e manter regras de negócios formuladas e consistentes com o Modelo de Objetivos (MO). São regras que controlam a organização no sentido de definir e restringir quais ações podem ser executadas em várias situações. Podem ser:

- Declarações precisas que descrevem o método escolhido pelo negócio para alcançar seus objetivos e implementar suas políticas;

- Regras impostas externamente sobre o negócio, tais como regulamentos e leis.

Existem algumas categorias para Regras do Negócio, segundo Pádua (2001):

- Regras Derivadas: são expressões que definem componentes derivados da estrutura da informação em termos de entidades que já estão presentes na base de informação do modelo da organização. Por exemplo: “ Um mau cliente de biblioteca é um cliente que não retorna o livro até a data limite por duas vezes consecutivas";

- Regras de Evento-Ação: expressam as condições sobre as quais as atividades devem ser realizadas, como um conjunto de condições disparadoras e/ou um conjunto de pré-condições que devem ser satisfeitos antes da sua execução. Por exemplo: "Se o retorno de um empréstimo está quatro dias atrasado, envie um lembrete";

- Regras de Restrição: estão ligadas à integridade da informação, à estrutura dos componentes, ou às atividades e comportamentos permitidos na organização. As regras de restrição podem ser estáticas, aplica-se a todo estado da base da informação e são independentes de tempo: "a locação de cada cópia do livro é única e apenas uma", podem ainda ser restrições de transição, especificando restrições no comportamento do sistema: "Uma cópia de livro está faltando, se o empréstimo dele está atrasado por mais de quatro semanas".

No Modelo de Regras do Negócio como no Modelo de Objetivos (MO), (figura 07, p. 74) existem dois tipos de relacionamento: relacionamento de apoio e relacionamento de impedimento e, existem também as estruturas de decomposição AND/OR. 


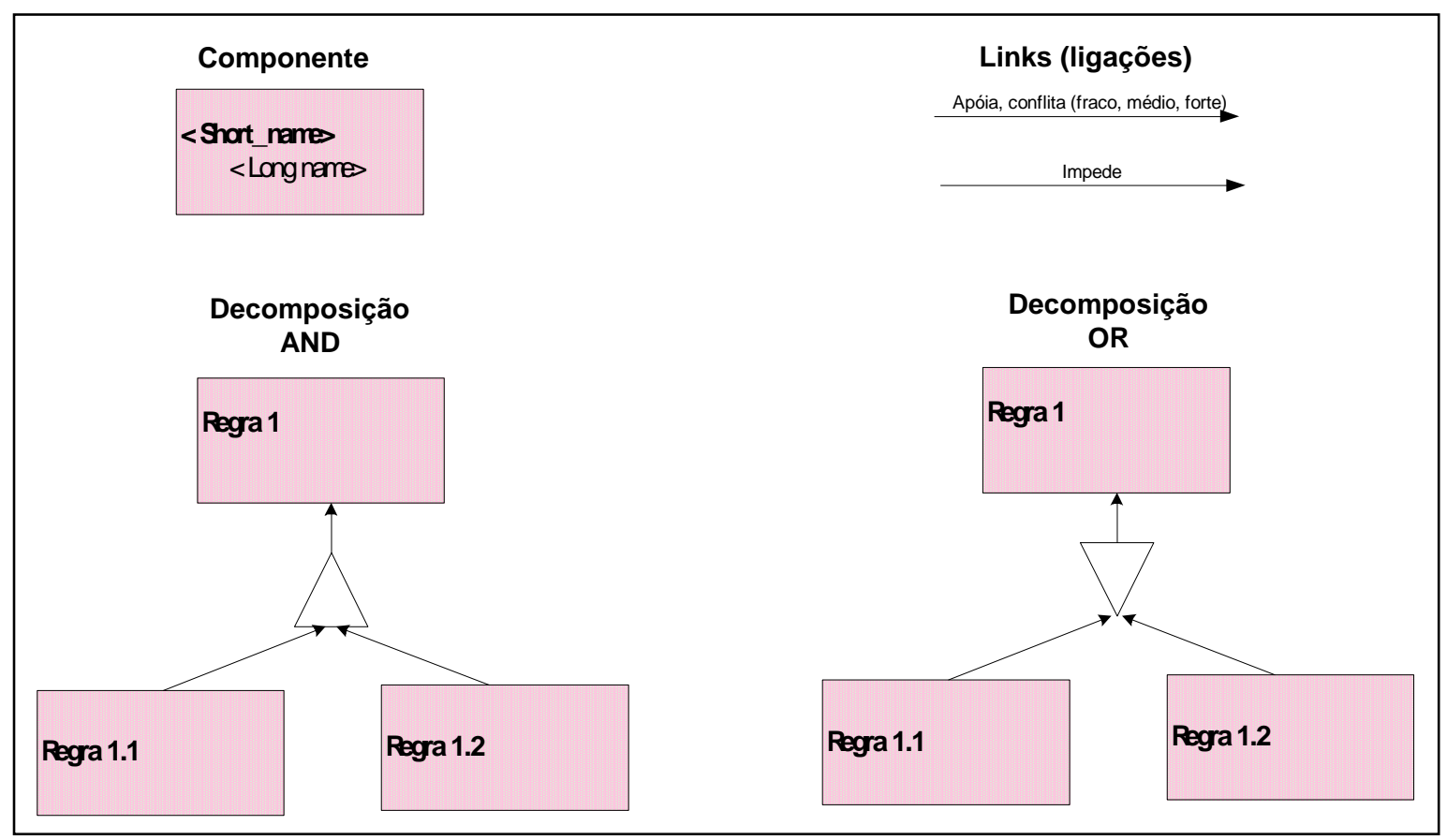

Figura 06 - Notações do Modelo de Regras do Negócio (MRN).

Fonte: Bubenko et al. (2001, p.39).

\subsubsection{Modelo de Conceitos}

O Modelo de Conceitos, como sub-modelo do Modelo Organizacional e, segundo Pádua (2001), é usado para definir coisas e fenômenos que estão em outros modelos, além de definir entidades e dados da aplicação em um nível conceitual, servindo como um dicionário.

Os componentes do modelo de Conceitos são:

- Entidades - alguma coisa do domínio de interesse e aplicação que deve ser entendida, caracterizada e definida usando relacionamento para outras entidades;

- Atributos de informação - é uma entidade utilizada apenas para caracterizar outra entidade. É uma propriedade de um tipo de objeto;

- Relacionamentos - podendo ser semânticos tais como: relacionamento binário (entre duas entidades e bi-direcionais); relacionamento generalização/ 
especialização (ISA) onde se "a" ISA “b”, então "b" é o conceito mais genérico e "a" é o conceito específico, o inverso caracteriza a especialização. Outro relacionamento é o PartOF ou a agregação, no qual as entidades inter-relacionadas são fortemente e firmemente acopladas umas as outras. O objeto agregado é uma reunião de partes, e as partes são componentes de agregação.

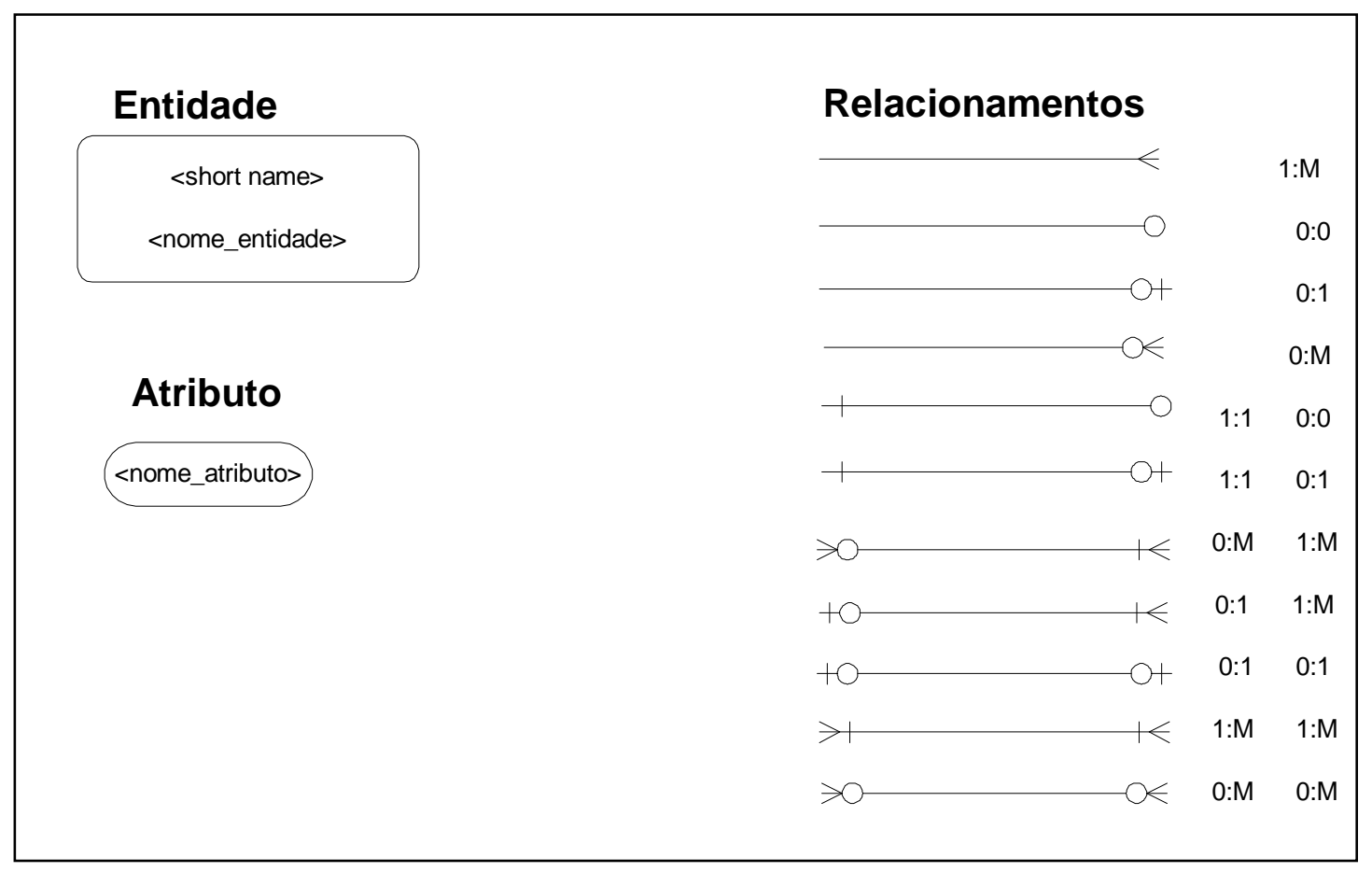

Figura 07 - Notações do Modelo de Conceitos (MC).

Fonte: Adaptado pela autora de Bubenko et al. (2001, p.46).

\subsubsection{Modelo de Processos do Negócio (MPN)}

O Modelo de Processos do Negócio possibilita a análise dos processos e do fluxo de informação e de material da organização. Descreve as atividades organizacionais (funções e processos da organização) que contribuem para os valores da mesma.

Este modelo é motivado pelos componentes do Modelo de Objetivos e também possibilita que os objetivos do Modelo de Objetivos sejam alcançados. O Modelo de Processos do Negócio pode ter um processo decomposto em sub-processos, dependendo do propósito da modelagem e possibilitando o alcance de uma boa abstração. (PÁDUA, 2001). 
Os componentes do Modelo de Processos (figura 9, p.76) são processos, processos externos e informações ou materiais:

- Processo - é uma coleção de atividades que consome entradas e produz saídas em termos de material ou informação. É controlado por um conjunto de regras que indicam como processar as entradas e produzir as saídas. O processo relaciona-se ao Modelo de Atores e Recursos (MAR);

- Processo externo - é uma coleção de atividades localizadas fora da atividade organizacional que comunica-se com processos ou atividades da área de domínio do problema e, são essenciais para a documentação;

- Informação ou Material - é o conjunto de informação ou material enviado de um processo para outro, seu conteúdo é descrito pelo Modelo de Conceitos (MC) onde são decompostos, se necessário. Necessitam ter ao menos um envio ou um recebimento de processo ou processo externo. (PÁDUA, 2001).

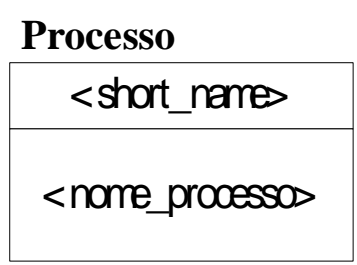

\section{Processo Externo}

<short_name>

<nome_ProcExt>

\section{Conjunto de Informação ou material}

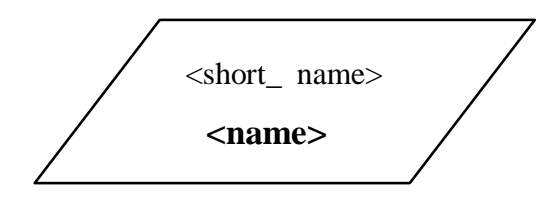

$\underset{\mathrm{Fluxo} \text { de Controle }}{\stackrel{\mathrm{P}}{\longrightarrow}}$
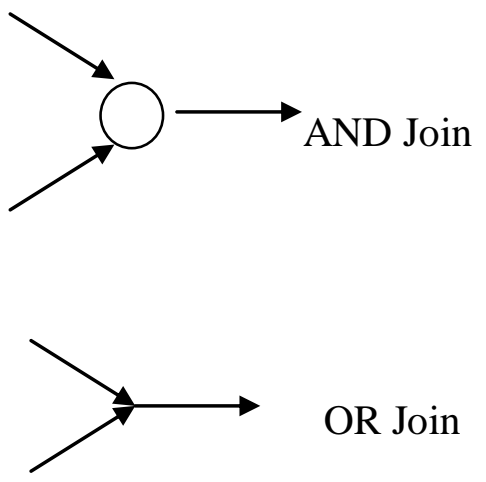

Figura 08 - Componentes do Modelo de Processos do Negócio (MPN).

Fonte: Bubenko et al. ${ }^{3}$ (1998 apud PÁDUA, 2001, p.110). 


\subsubsection{Modelo de Atores e Recursos}

O Modelo de Atores e Recursos (MAR), também sub-modelo do Modelo Organizacional, define quais e que tipo de atores e recursos estão envolvidos nas atividades organizacionais, descrevendo os relacionamentos entre si e componentes do Modelo de Objetivos e, estes com o Modelo de Processos do Negócio. (PÁDUA, 2001).

Atores e recursos podem ser:

- Individual - uma pessoa;

- Unidade Organizacional - grupo, departamento, divisão, projeto, entre outros, podendo ter sub-unidades;

- Recursos não humanos - tipos de máquinas, sistemas e equipamentos, podendo ter componentes, ser generalizados ou especializados e executar tarefas;

- Tarefa (também com o sentido de papel) - podem ser executadas por unidades organizacionais em contextos diferentes, podem também, ser especializadas, generalizadas e tarefas componentes.

Os relacionamentos entre componentes do Modelo de Atores e Recursos e componentes de outros sub-modelos são definidos por: responsabilidade, relacionada com a execução de tarefas e dependência operacional ou de autoridade.

No Modelo de Atores e Recursos, os relacionamentos são do tipo ISA e PartOF.

Notação

Atores e Recursos

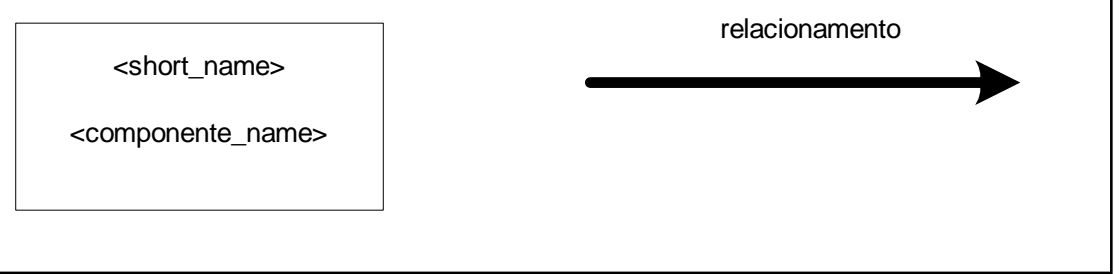

Figura 09 - Componentes do Modelo de Atores e Recursos (MAR)

Fonte: Bubenko et al. (2001, p.59) 


\subsubsection{Modelos de Requisitos e componentes técnicos}

O Modelo de Requisitos e Componentes Técnicos é uma tentativa inicial de se definir as estruturas e propriedades do sistema de informação para apoiar as atividades do negócio, como definido no Modelo de Processos do Negócio.

Não sendo o objetivo deste trabalho, desenvolver um sistema de informação para apoiar processos, este Modelo não será abordado.

\subsubsection{Relacionamentos entre os sub-modelos}

De acordo com Pádua (2001, p.116) “as ligações, ou seja, os relacionamentos entre modelos, tornam o conhecimento mais disponível, sendo possível ver porque certos processos e requisitos do sistema de informação têm que ser introduzidos".

- Ligações entre o Modelo de Objetivos e o Modelo de Conceitos são usadas para descrever componentes do Modelo de Objetivos que referenciam entidades do Modelo de Conceitos;

- Ligações entre o Modelo de Objetivos e o Modelo de Processos do Negócio geralmente são representados com o relacionamento "motiva";

- Ligações entre o Modelo de Objetivos e o Modelo de Atores e Recursos podem motivar ou requerer a introdução de novos atores particulares ou descrever quais componentes do Modelo de Atores e Recursos são responsáveis para alcançar determinado objetivo ou defini-lo;

- Ligações entre o Modelo de Objetivos e o Modelo de Regras do Negócio representam como diferentes componentes do Modelo de Objetivos são implementados em termos de regras do negócio;

- Ligações entre o Modelo de Regras do Negócio e o Modelo de Processos do Negócio indicam como os processos são disparados pelas regras do negócio;

- Ligações entre o Modelo de Processos do Negócio e o Modelo de Conceito: onde conceitos são usados para detalhar melhor as informações (entidades, atributos e relacionamentos) do Modelo de Processos do Negócio; 
- Ligações entre o Modelo de Processos do Negócio e o Modelo de Atores e Recursos servem para identificar envolvimento, relacionamento, ações: realiza, é responsável por, apóia.

- Ligações entre o Modelo de Atores e Recursos e o Modelo de Regras de Negócio descrevem como componentes do Modelo de atores e Recursos se relacionam com as Regras de Negócio do Modelo de Processos do Negócio.

\subsection{Considerações finais}

A metodologia Enterprise Knowledge Development (EKD) foi apresentada no presente capítulo envolvendo as informações que serão utilizadas a fim de verificar a existência de contribuição da mesma ao desenvolvimento da Gestão do Conhecimento envolvendo: geração, codificação, disseminação e apropriação de conhecimento.

Como já fora citado anteriormente, a metodologia Enterprise Knowledge Development (EKD) pode ser utilizada no gerenciamento de conhecimento organizacional ou aprendizagem organizacional para formar a base de propagação e ampliação de conhecimento.

Até o presente momento deste trabalho, pudemos em breves palavras verificar:

- Capítulo 2 - a necessidade de mudanças na forma de Gestão da Administração Pública decorrente de toda uma mudança contextual, com o objetivo de eficiência e eficácia na prestação de serviços deste setor da economia. Foram também apresentadas opiniões de escritores a respeito de teorias a serem adotadas a fim de que se promovam as mudanças necessárias;

- Capítulo 3 - a apresentação dos conceitos de Gestão do Conhecimento, citada por alguns autores no Capítulo 1 como forma de gestão ultimamente aplicada às grandes organizações com resultados positivos em flexibilidade, produtividade e competitividade;

- Capítulo 4 - De maneira sucinta, fora apresentada a Metodologia de Modelagem Organizacional EKD que, neste contexto, será utilizada, em partes, 
a fim de juntamente a outras bases teóricas selecionadas, possa constituir um método de trabalho a ser proposto como objetivo principal.

O Capítulo seguinte estará apresentando o método de trabalho proposto, pautando-se em sua maior parte nas bases teóricas já apresentadas. 


\section{PROPOSIÇÃO DO MÉTODO DE TRABALHO}

\subsection{Considerações iniciais}

A finalidade deste capítulo é propor um método de aplicação para a Gestão do Conhecimento utilizando a metodologia de Modelagem Organizacional Enterprise Knowledge Development (EKD).

A redundância teórica, ora encontrada, torna-se necessária para justificar as ações a serem tomadas e sequenciar as etapas a serem aplicadas.

Serão introduzidas informações do setor de Alimentação Escolar do município de São Carlos, quando necessárias, a fim de ilustrar situações e demandas para cada uma das etapas a serem apresentadas.

\subsection{O Programa de alimentação escolar no município de São Carlos, SP}

A cidade de São Carlos, SP é um dos cerca de 5.560 mil municípios brasileiros envolvidos no Programa Nacional de Alimentação Escolar (PNAE), do Fundo Nacional de Desenvolvimento da Educação (FNDE), Ministério da Educação (MEC) para o qual são destinados cerca de $\mathrm{R} \$ 1,025$ bilhão ao ano (2004), a fim de subsidiá-lo. 


\begin{tabular}{|c|c|c|}
\hline Ano & $\begin{array}{c}\text { Recursos financeiros } \\
\text { (em milhões de R\$) }\end{array}$ & $\begin{array}{c}\text { Alunos atendidos } \\
\text { (em milhão) }\end{array}$ \\
\hline 1995 & 590,1 & 33,2 \\
\hline 1996 & 454,1 & 30,5 \\
\hline 1997 & 672,8 & 35,1 \\
\hline 1998 & 785,3 & 35,3 \\
\hline 1999 & 871,7 & 36,9 \\
\hline 2000 & 901,7 & 37,1 \\
\hline 2001 & 920,2 & 37,1 \\
\hline 2002 & 848,6 & 36,9 \\
\hline 2003 & 954,2 & 37,3 \\
\hline 2004 & $1.025,0$ & 37,8 \\
\hline
\end{tabular}

Tabela 01- Dados estatísticos sobre recursos aplicados e clientela atendida pelo PNAE. Fonte: http://www.fnde.gov.br

O Programa no município de São Carlos adota o Sistema municipalizado, proposto através do processo de descentralização ocorrido em 1994 pelo Governo Federal, ou seja, a Prefeitura é a Entidade Executora (EE) do Programa, que responde pelo atendimento na rede municipal e estadual através das atividades de elaboração de cardápios; aquisição de alimentos (através de licitações); contratação de recursos humanos; oferta e instalação de infra-estrutura física, equipamentos e utensílios, etc.

Outra característica importante do sistema adotado no município de São Carlos é a de manter uma central administrativa com capacidade para armazenamento de gêneros alimentícios não-perecíveis, sendo o preparo e distribuição das refeições feitos nas cozinhas existentes nas próprias Unidades Escolares que atendem aos beneficiados (sistema descentralizado).

Atualmente, o Programa atende cerca de 36.000 crianças no município, distribuídas em 90 Unidades Escolares e servindo cerca de 55.000 refeições por dia, (FIGURA 10, P.83): 


\begin{tabular}{|l|c|c|}
\hline \multicolumn{1}{|c|}{ Tipo de atendimento } & Número de Unidades & Número total de alunos \\
\hline $\begin{array}{l}\text { Creches municipais } \\
\text { filantrópicas }\end{array}$ & $\frac{14}{21}$ & $\begin{array}{c}1.148 \\
\frac{759}{1.907}\end{array}$ \\
\hline $\begin{array}{l}\text { Escolas Municipais de } \\
\text { Educação Infantil - EMEIs }\end{array}$ & 28 & 6.970 \\
\hline $\begin{array}{l}\text { Escolas Municipais de } \\
\text { Educação Básica - EMEBs }\end{array}$ & 08 & 6.703 \\
\hline $\begin{array}{l}\text { Escolas Estaduais (apenas } \\
\text { ensino fundamental) }\end{array}$ & 28 & 17.144 \\
\hline $\begin{array}{l}\text { Atendimentos especiais } \\
\text { (APAE, SESIs, etc) }\end{array}$ & 05 & 2.995 \\
\hline Total geral & $\mathbf{9 0}$ & $\mathbf{3 5 . 7 1 9}$ \\
\hline
\end{tabular}

Figura 10 - Número de unidades e alunos por tipo de atendimento realizado pela alimentação escolar São Carlos, SP. mar. 2004 Fonte: Prefeitura Municipal de São Carlos-SP

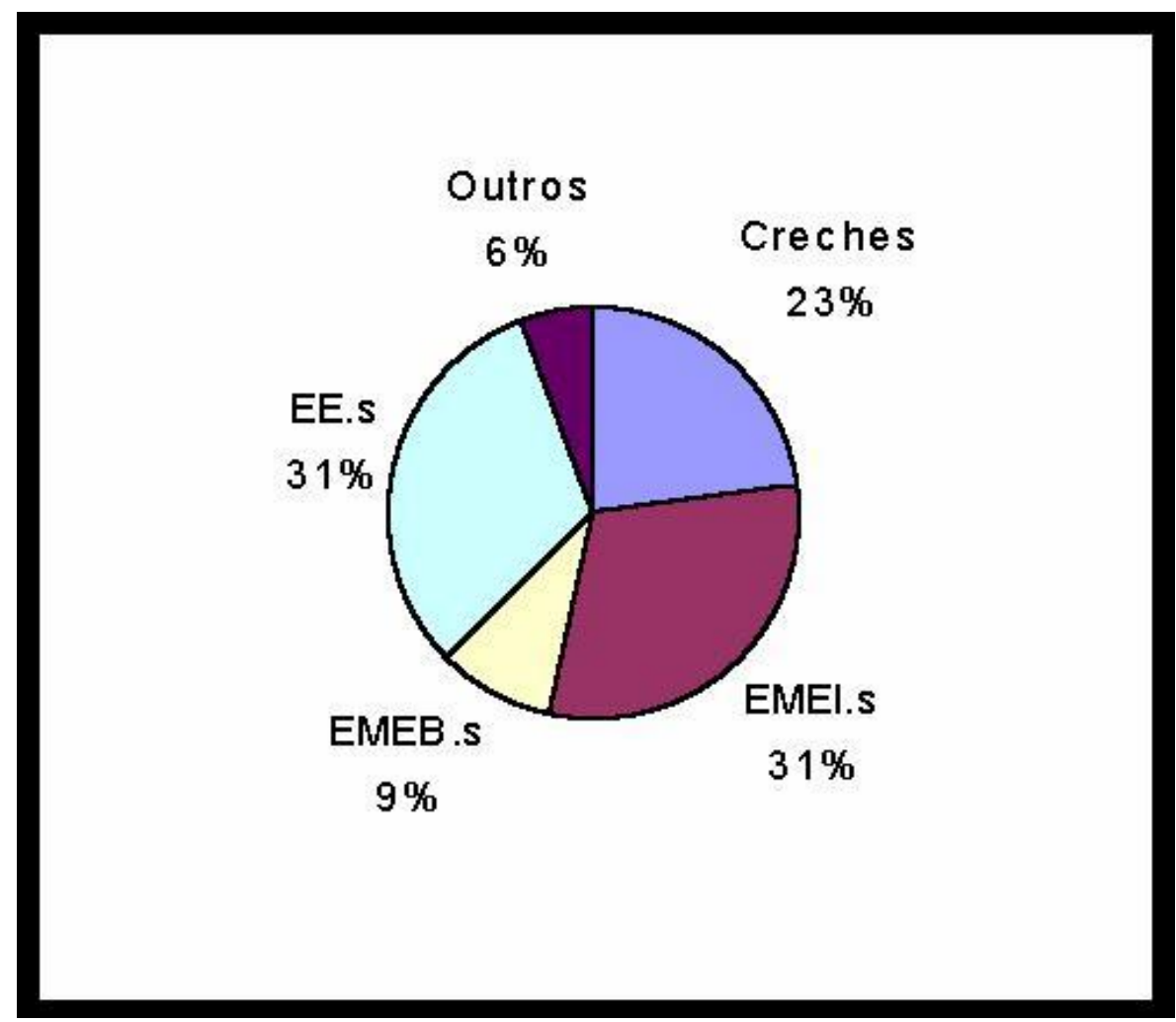

Figura 11 - a proporcionalidade de Unidades Escolares atendidas em mar.2014. Fonte: Prefeitura Municipal de São Carlos-SP 


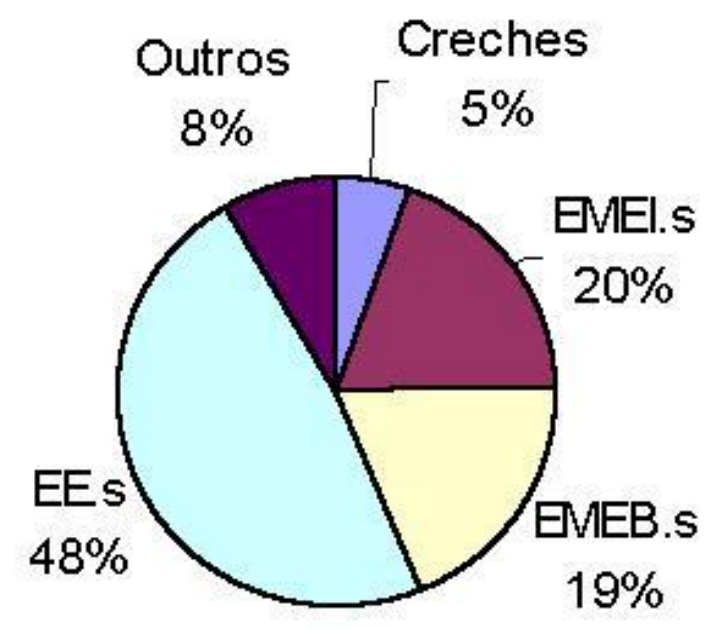

Figura 12 - proporcionalidade de alunos atendidos. Marc 2004. Fonte: Prefeitura Municipal de São Carlos-SP

Para um melhor entendimento quanto à divisão em níveis escolares, é apresentada a (figura 13), de acordo com a nova Lei de Diretrizes e Bases da Educação (LDB), Lei 9.394 de 20 de dezembro de 1996:

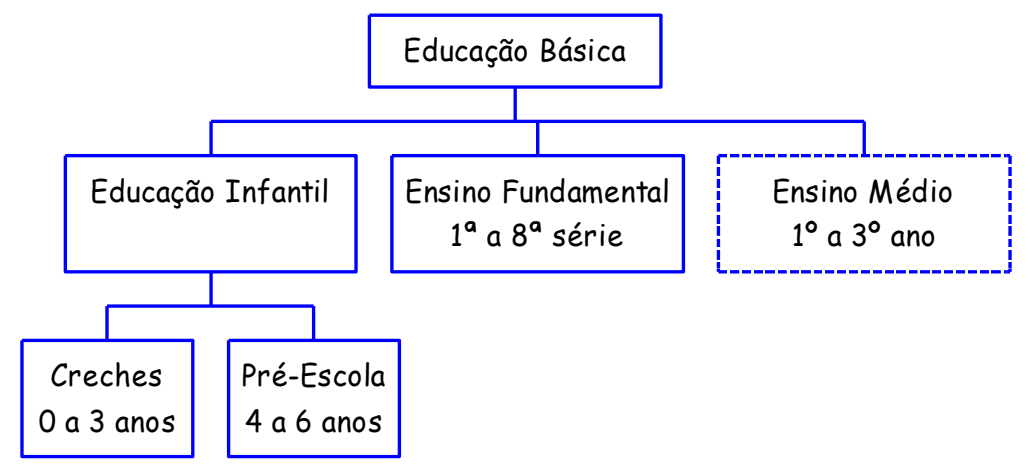

Figura 13 - Níveis escolares da Educação Básica de acordo com a Lei 9.394/96. Fonte: Elaborado pela autora 
Para o cálculo da quantidade de alimentos necessários às Unidades Escolares, os alunos do Ensino Médio não são considerados, pois estes não são beneficiados oficialmente pelo Programa Nacional de Alimentação Escolar (PNAE) através do repasse financeiro.

No município de São Carlos o Programa de Alimentação Escolar está sob a responsabilidade da Divisão de Alimentação Escolar (DAE), órgão do Departamento de Educação da Secretaria Municipal de Educação e Cultura (SMEC). (Figura 14)

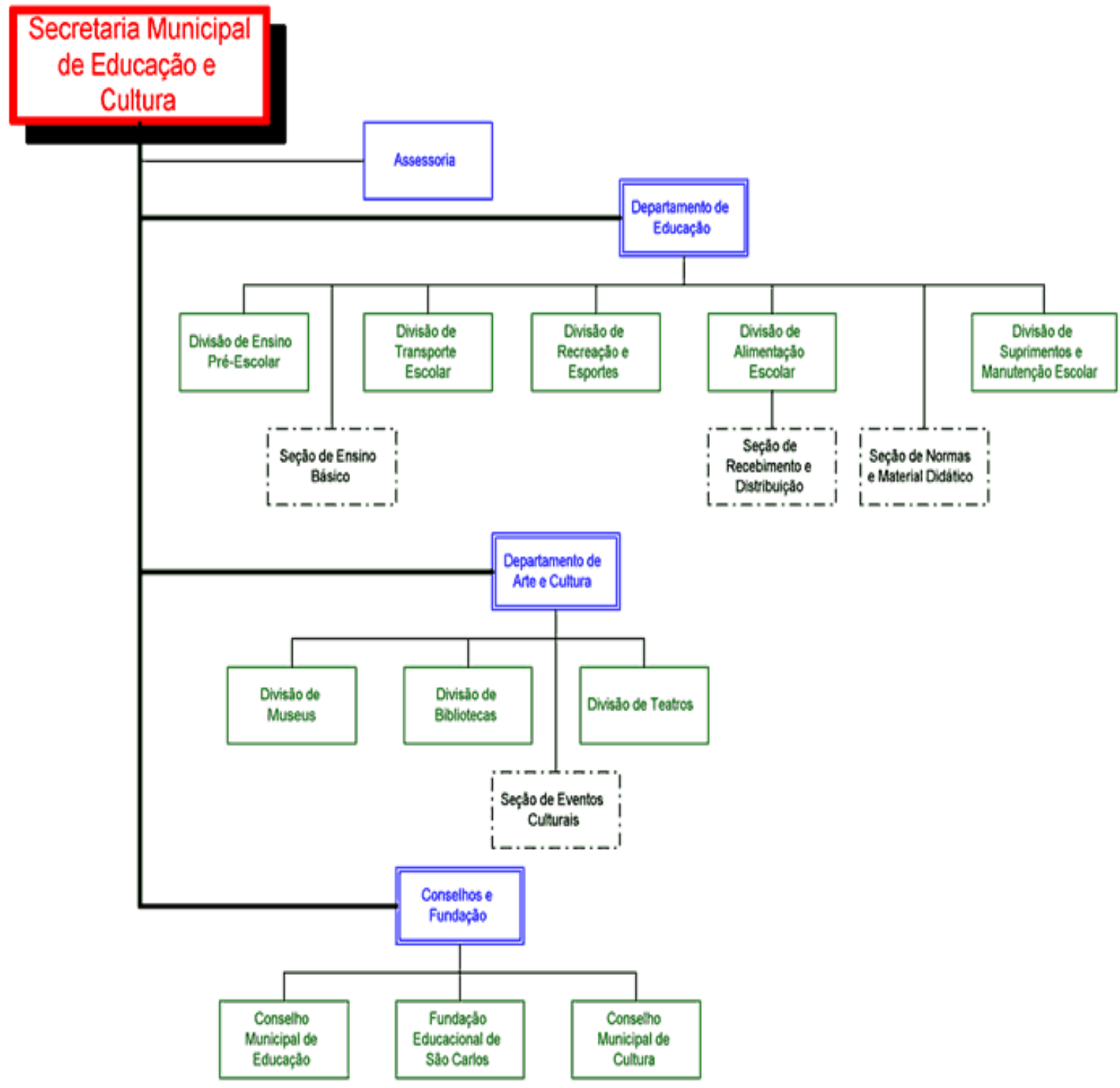

Figura 14 - Organograma da Secretaria Municipal de Educação e Cultura Fonte: Disponível em: < http://www.saocarlos.sp.gov.br/smed.htm> Acesso em: 4 ago. 2003. 
A Divisão de Alimentação Escolar é responsável pelo Programa no município e, deve ter como objetivo principal, atender às necessidades nutricionais dos alunos, durante sua permanência em sala de aula, contribuindo para o crescimento e desenvolvimento dos alunos; a aprendizagem e o rendimento escolar; bem como a formação de hábitos alimentares saudáveis.

Por se tratar de um programa que recebe repasse dos governos federal e estadual, o mesmo tem como órgãos fiscalizadores de sua execução: o Conselho de Alimentação Escolar (CAE) formado por diversas representações dentro do município e o Tribunal de Contas do Estado e da União, que realizam auditorias anuais por amostragem, na documentação comprobatória tanto da aplicação dos recursos como da origem e destinação dos gêneros adquiridos para o Programa.

Atualmente a Divisão de Alimentação Escolar do município de São Carlos conta com a estrutura funcional administrativa descrita no organograma a seguir:

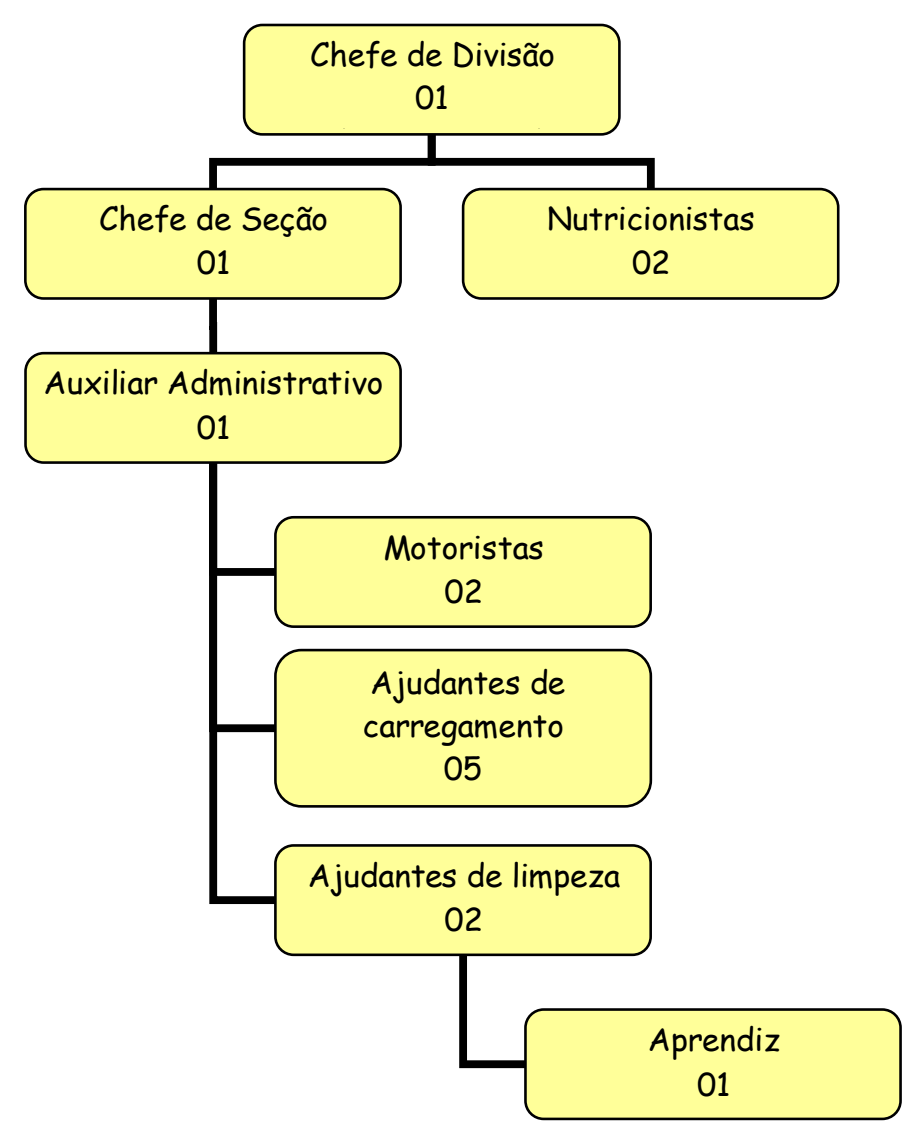

Figura 15 - Organograma administrativo da Divisão de Alimentação Escolar de São Carlos, SP. Fonte: Prefeitura Municipal de São Carlos-SP 


\subsubsection{Das dificuldades encontradas}

Como se pode perceber pelo organograma da Divisão, o número de profissionais para administrar o Programa é muito pequeno, considerando o volume de documentação necessária para sua comprovação.

Como são diversas as atribuições da equipe técnica responsável, estas acabam sobrecarregadas de atividades operacionais em detrimento da real utilização de sua qualificação na orientação preventiva e no controle externo da execução do programa.

Desde 2001, sob nova administração política, a gestão municipal do Programa de Alimentação Escolar no município, vem sofrendo modificações a fim de se adequar à legislação existente. Dada a urgência em praticar o Programa no município devido ao alto consumo e rotatividade de gêneros alimentícios a serem adquiridos e distribuídos e, considerando a alimentação escolar como sendo um serviço indispensável à população e alvo de acompanhamentos pela Câmara Municipal e pela mídia, as modificações foram sendo aplicadas, sem que, anteriormente houvesse um Planejamento Estratégico documentado.

Desta maneira, após modificações já implantadas, uma das maiores dificuldades encontradas é o comprometimento dos profissionais do setor com o desempenho de suas funções. Não existe um conhecimento coletivo sobre missão, objetivos, processos, etc que muitas vezes acarretam em tomada de decisões incorretas pelos profissionais do setor.

Hoje existe no setor uma rotina de trabalho praticada e tácita, ou seja os processos não estão documentados e explícitos a todos os componentes da equipe. $\mathrm{O}$ setor também possui um sistema precário de arquivamento manual sem qualquer registro da documentação existente e arquivada em qual local. Existem três microcomputadores interligados em rede local, que apresentam grande redundância de arquivos eletrônicos e que também, não são de conhecimento de todos. 
Durante os anos que antecederam 2001, a prática adotada para a Gestão deste Programa propiciou que o mesmo fosse, apesar de, ao julgamento dos Tribunais de Contas estar legalmente correto quanto à documentação comprobatória da aplicação dos recursos recebidos, foi julgada pela atual administração após acesso a documentações existentes, com problemas diversos que apontam a um parecer contrário .

Um problema bastante comum quanto à operacionalização do Programa de Alimentação Escolar a nível nacional é que este representa uma possibilidade para o desvio de dinheiro público.

A mídia brasileira, vez ou outra, veicula informações sobre estes acontecimentos, pois como alegam Trevisan et al. (2003, p.21) "as quadrilhas têm aperfeiçoado as suas formas de atuar. Por isso, é preciso que os controles por parte da sociedade também se aprimorem.”

Ainda segundo Trevisan et al. (2003) o Tribunal de Contas, um dos órgãos responsáveis pela fiscalização do Programa, acaba por verificar apenas os aspectos formais das despesas, sem entrar no mérito de verificar se a nota fiscal contabilizada é "fria" ou não; se a empresa fornecedora existe legalmente ou não; se o preço do serviço prestado é compatível com o mercado ou não e, se o procedimento licitatório foi conduzido adequadamente ou não.

Essas deficiências colaboram para a falta de profissionalismo, normalmente encontrada nos setores responsáveis pela Alimentação Escolar dos municípios. Os maus gestores desse Programa, a nível municipal, não se preocupam em implantar normas e procedimentos que o torne transparente e, geralmente, não respeitam as determinações legais em nenhum dos processos que envolvem o Programa, dentre eles: planejamento de cardápios, aquisições de gêneros, recebimento e estocagem, distribuição de gêneros e controle nas Unidades, quando a realidade for de descentralização no preparo das refeições.

Tohá e Solari (2004), afirmam que a maior transparência na administração é, ao mesmo tempo, uma forma de responder ao público e uma maneira de dinamizar os 
sistemas de controle, de baixo custo e alta eficácia política. Quando a informação é acessível e clara, quando as contas públicas são exigíveis, o controle dos cidadãos pode tornar-se mais efetivo e adequado que os controles estritamente administrativos. Na época em que a corrupção se transforma num mal tão difundido, esta pode ser uma estratégia para detê-la.

Explicitadas as dificuldades acima, estaremos propondo uma mudança de Gestão administrativa que procure saná-las: desenvolvendo os modelos que compõem a EKD, através das atividades da Gestão do Conhecimento, disseminando o conhecimento tácito existente a todos os profissionais do setor.

\subsection{Do método de trabalho}

\subsubsection{Etapa 1 - Apresentação dos propósitos da atividade a ser desenvolvida, definição da equipe de trabalho e a metodologia a ser seguida:}

Pádua (2001) apresenta um conjunto de pré-condições necessária à aplicação da metodologia EKD na organização:

- Os envolvidos na modelagem deverão ter uma visão clara da atividade, alocar tempo e recursos necessários ao processo de modelagem, serem originários de todos os setores da organização, procurando agrupar todos os conhecimentos necessários ao negócio e possuírem autoridade para reprojetar a organização;

- As atividades de modelagem deverão considerar as questões a serem discutidas, quem serão os participantes, suas tarefas e qual tempo será utilizado;

- Devem ser realizados entrevistas ou questionários prévios com os envolvidos, pois esta possibilita uma visão melhorada das pessoas que participam nas sessões de modelagem e de suas visões, problemas, esperanças, preconceitos e sentimentos;

- O primeiro seminário deverá ser organizado de maneira a garantir o trabalho concentrado numa atmosfera mais tranqüila e sem interrupções; 
Dependendo do contexto a ser trabalhado, levando-se em conta a diversidade de formação tanto educacional quanto profissional que causam uma disparidade entre os envolvidos na equipe, a linguagem adotada deverá ou não possuir níveis distintos: $\mathrm{Na}$ situação considerada para ilustrar as etapas a serem apresentadas, tem-se:

- Um nível a ser utilizado com todos, portanto mais simples possível, a fim de coletar informações e;

- Um segundo nível que será tratado apenas com a equipe técnica do setor e ficará com a responsabilidade de aplicação e modelagem da metodologia EKD.

A aplicação do presente método não deverá comprometer a rotina de trabalho dos profissionais do setor sendo desta forma, tratado um assunto por encontro (seminário).

Todos os conhecimentos a serem construídos, o serão de maneira coletiva e para tanto serão utilizados as atividades e os pressupostos da Gestão do Conhecimento anteriormente apresentadas no Capítulo 3:

\begin{tabular}{|c|c|c|}
\hline $\begin{array}{l}\text { Atividades da } \\
\text { Gestão do } \\
\text { Conhecimento }\end{array}$ & No que consiste & $\begin{array}{l}\text { Modos de conversão do } \\
\text { conhecimento }\end{array}$ \\
\hline Geração & $\begin{array}{l}\text { Criar/ adquirir/ localizar conhecimentos nos } \\
\text { processos da organização }\end{array}$ & \\
\hline Codificação & $\begin{array}{l}\text { Organizar / armazenar conhecimento existente e } \\
\text { utilizado na execução dos processos }\end{array}$ & - Socialização \\
\hline Disseminação & $\begin{array}{l}\text { Distribuir / compartilhar conhecimentos certos } \\
\text { para as pessoas certas. }\end{array}$ & - Externalização \\
\hline Apropriação & $\begin{array}{l}\text { Os envolvidos são capazes de fornecer } \\
\text { conhecimento relevante, no momento adequado, } \\
\text { de forma pró-ativa e de acordo com seu perfil. }\end{array}$ & $\begin{array}{ll}\text { - } & \text { Combinação } \\
\text { - } & \text { Internalização }\end{array}$ \\
\hline
\end{tabular}

Figura 03, Capítulo 3 - Atividades e pressupostos da Gestão do Conhecimento Elaborado pela autora 


\subsubsection{Etapa 2 - Desenvolvimento da missão do negócio}

Partindo do pressuposto de que a etapa 1 (um) foi concluída, deverá ser agendado novo seminário para que se apresente e desenvolva o conceito de missão do setor (negócio) que respeitará os passos apresentados a seguir, explorando conceitos da Gestão do Conhecimento.

O Método aqui proposto compreende basicamente os seis passos a seguir expostos (A a F) que tratam da Gestão do Conhecimento e a utilização de conceitos e notificações da Enterprise Knowledge Development (EKD), para introdução de cada assunto, bem como para a codificação dos Modelos:

A - O conceito missão da empresa será apresentado a todos os profissionais do setor de forma verbal pela pessoa responsável por dirigir e orientar as atividades;

Conceitualmente: De acordo com os modos de conversão do conhecimento, este é um momento de socialização - do conhecimento tácito para o conhecimento tácito, e está sendo aplicada a atividade de Disseminação de Conhecimento individual.

B - A cada um, será disponibilizado documentalmente, o conceito e, de três a cinco exemplos de missões de empresas conhecidas;

Conceitualmente: pratica-se um momento de externalização do conhecimento tácito para o conhecimento explícito (emitente) e internalização do conhecimento explícito ao conhecimento tácito (receptor) e a atividade da Gestão do Conhecimento neste contexto é a Apropriação de um novo conhecimento/conceito.

C - O documento disponibilizado será levado pelos profissionais e será utilizado para que cada um, a partir de seu modelo mental ${ }^{8}$, expresse a sua proposta também de forma escrita, para a definição da missão do setor.

\footnotetext{
${ }^{8}$ Modelo mental: inclui idéias arraigadas e paradigmas que interferem sobre as nossas atitudes, muitas vezes sem que tenhamos consciência disso. (SENGE, 1990).
} 
Conceitualmente: Temos mais uma vez um momento de externalização do conhecimento tácito para o conhecimento explícito. E caracteriza-se a atividade de Codificação do Conhecimento.

D - Um novo encontro é marcado para a apresentação de cada ponto de vista, discussão e construção coletiva da conceituação final de missão do setor ;

Conceitualmente: De acordo com os modos de conversão do conhecimento, praticam-se os momentos de socialização e combinação de conhecimentos, pois temos a exposição de conhecimentos antes tácitos e agora explícitos e o rearranjo dos mesmos para a formalização de um único conhecimento explícito. Quanto as atividade da Gestão do Conhecimento, estão sendo utilizadas a Disseminação e a Criação do Conhecimento Coletivo.

E - A missão da empresa é codificada em forma de folhetos, filipetas ou cartazes; Conceitualmente: Pelos modos de conversão do conhecimento, pratica-se a externalização do conhecimento tácito para o conhecimento explícito, tratandose também da atividade de Codificação do Conhecimento.

F - A missão já codificada é exposta em local de livre acesso aos profissionais, desta vez, internos e externos ao setor;

Conceitualmente: Temos, de acordo com os modos de conversão do conhecimento, o momento de internalização do conceito exposto - do conhecimento explícito para o conhecimento tácito e, representada, a atividade de Disseminação do Conhecimento com consequiente Apropriação do mesmo. 


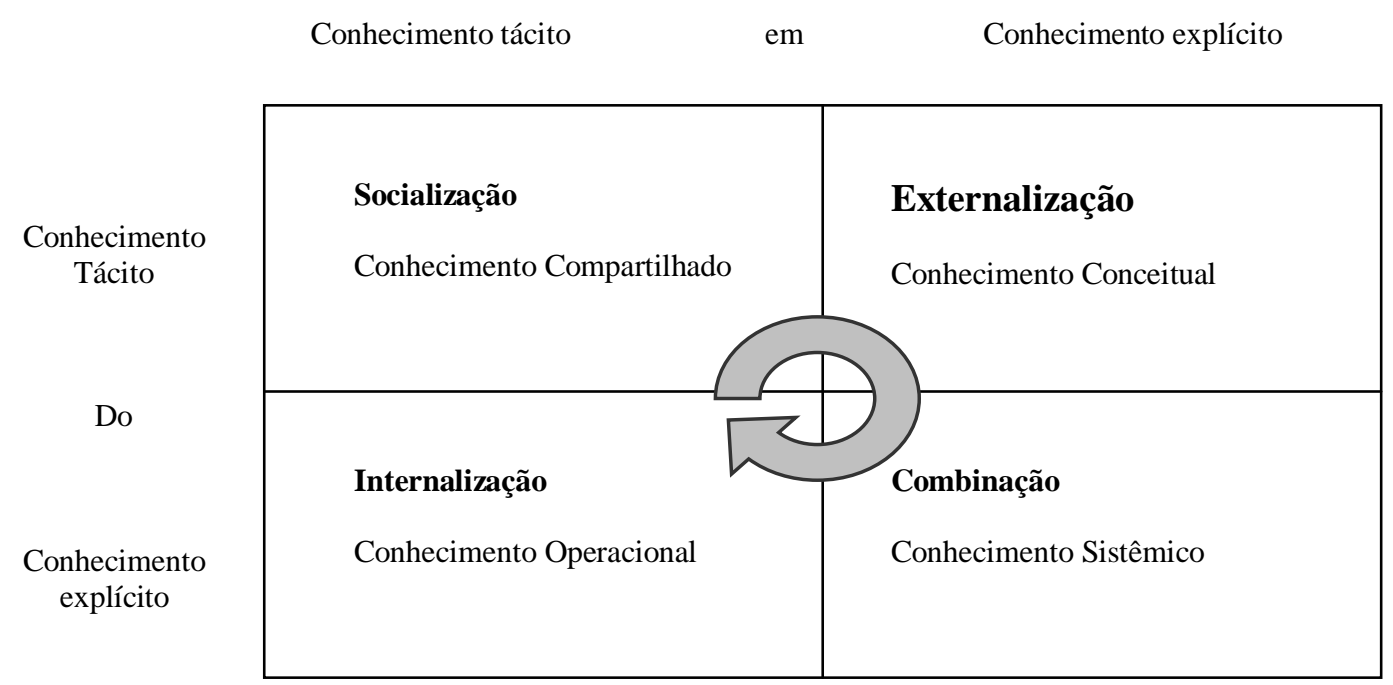

Figura 03, Capítulo 2 - Conteúdo do conhecimento criado pelos quatro modos de conversão. Fonte: Nonaka e Takeuchi, (1997, p. 81).

As etapas seguintes serão trabalhadas da mesma forma como a etapa 2, utilizando como ferramenta conceitual e de execução, o Modelo Organizacional apresentado pela metodologia Enterprise Knowledge Development (EKD), excetuandose o desenvolvimento do Modelo de requisitos e componentes técnicos, pois este, como já fora dito, é utilizado para desenvolvimento de software, não sendo esse o objetivo deste trabalho.

A utilização da EKD para o desenvolvimento da Gestão do Conhecimento vem ao encontro de diversas possibilidades apresentadas pelos autores citados no Capítulo 2 para a melhoria da Gestão da Administração Pública:

- O ajuste das estratégias, mediante a redefinição de suas missões, de seus objetivos e de suas metas. (MINISTÉRIO DO PLANEJAMENTO, ORÇAMENTO E GESTÃO_SECRETARIA DE GESTÃO, 2004);

- a redefinição explícita da missão de cada órgão. Para adequar o funcionamento do órgão à sua missão é desenvolvido o planejamento estratégico, estabelecemse objetivos e metas, definem-se atividades e programas, clientes e usuários, prioridades e prazos. (TOHÁ E SOLARI, 2004); 
- Clareamento e Visão - definição de estratégia e objetivos. Visão da organização no futuro partilhada por todos, o que vai mantê-los unidos em torno de uma identidade e sentido de destinos únicos. (SAXENA, 2004).

Modelo Organizacional da Enterprise Knowledge Development (EKD) :

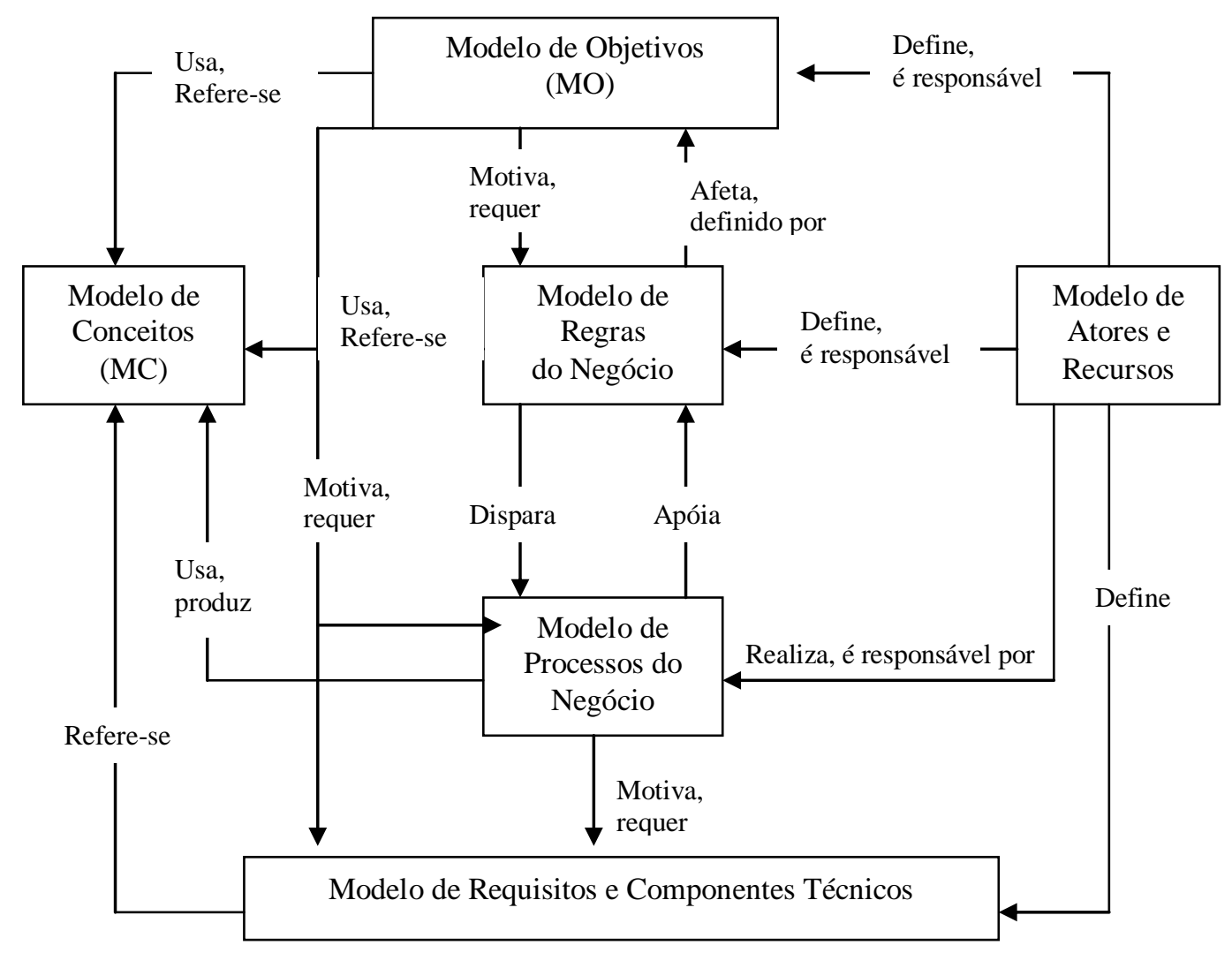

Figura 04, Capítulo 4 - Submodelos que compõem o Modelo Organizacional. Fonte: BUBENKO et al. (1998) apud PÁDUA (2001, p.80)

\subsubsection{Etapa 3 - Desenvolvimento dos objetivos do negócio, de acordo com os conceitos tratados pela metodologia Enterprise Knowledge Development (EKD)}

Os passos a serem seguidos serão os mesmos apresentados pela etapa 2 dos itens A ao item F, desta vez, utilizando como meio a metodologia Enterprise Knowledge Development (EKD), buscando como fim a Gestão do Conheicmento.

A atividade de apresentação do conceito de objetivo terá como fonte teórica inicial o conceito da EKD, para que se construa coletivamente o Modelo de Objetivos 
do negócio, serão aplicados os passos $\mathrm{A}$ ao $\mathrm{F}$ integrados, quando necessário, Às notações do Modelo sugeridas pela Enterprise Knowledge Development (EKD) .

Estes são os encaminhamentos básicos a serem utilizados como método para desenvolver qualquer Modelo necessário ao negócio considerado, podendo ser acrescido, ou decrescido de informações convenientes, ficando esta decisão a critério de toda a equipe no decorrer das atividades.

O presente Método ao ser aplicado deverá respeitar a flexibilidade necessária a absorver colaborações no sentido de enriquecimento das ações futuras.

Para a construção e codificação do Modelo de Objetivos serão respeitados os conceitos e notações apresentadas no item 4.3.1_Capítulo 4 considerando, como já fora dito, a disparidade entre os envolvidos.

Para ilustrarmos a situação acima apresentaremos um modelo de objetivos (figura 16, p.96), desenvolvido apenas pela equipe técnica do setor através da realização de uma reunião. Este desenvolvimento deu-se apenas para a familiarização com a metodologia adotada. 


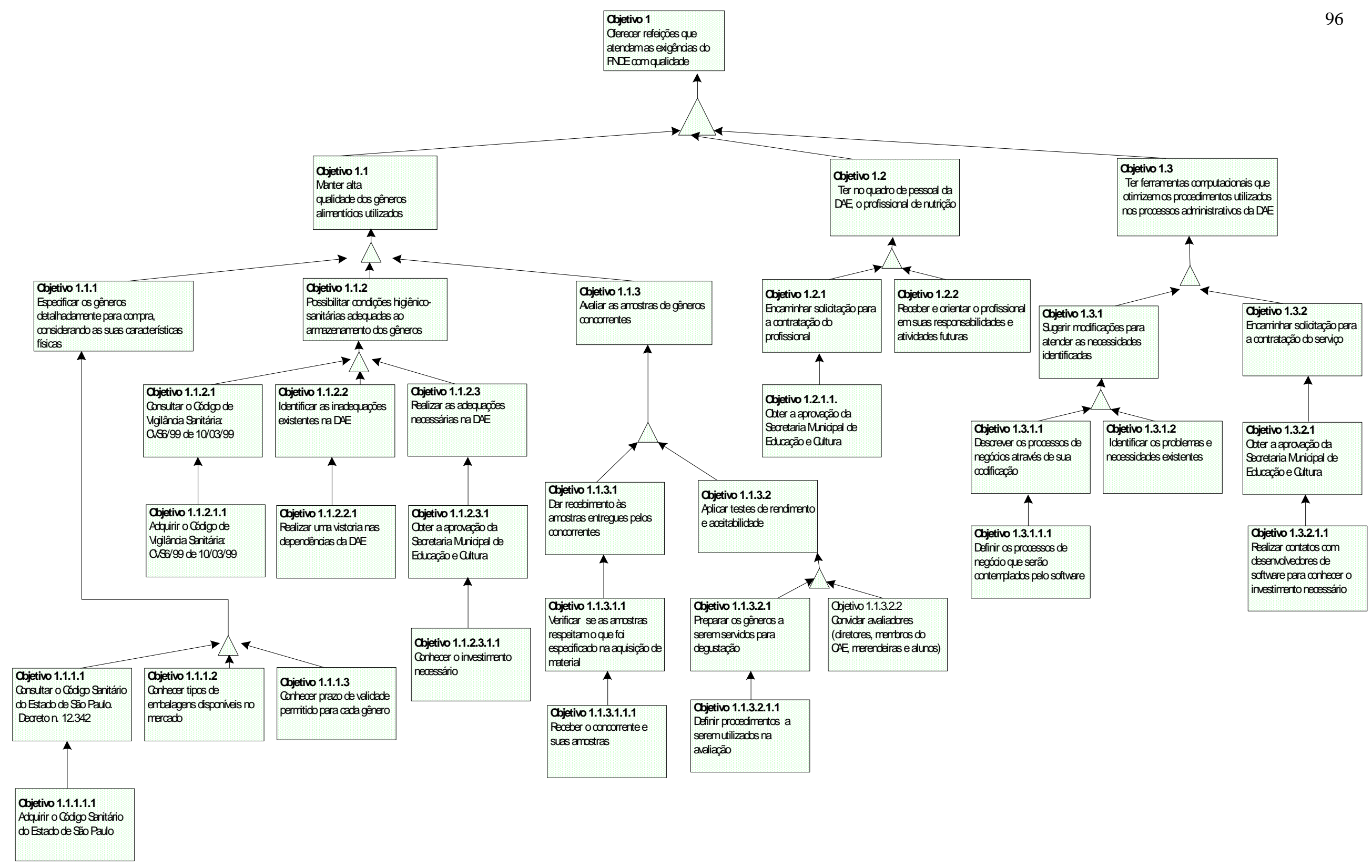

Figura 16 - Modelo de Objetivos (MO) da Divisão de Alimentação Escolar (DAE) de São Carlos, SP Fonte: Elaborado pela autora 


\subsubsection{Etapa 4 - Desenvolvimento do modelo de processos do negócio}

Para o desenvolvimento deste modelo alguns dados podem ser apresentados com relação ao setor de alimentação escolar do município de São Carlos, SP. São apresentados através de relato sobre a prática de 5 (cinco) processos que acontecem no referido setor.

Cabe aqui informar que ao desenvolver o Modelo de Processos de Negócio fica possibilitado o desenvolvimento concomitante do Modelo de Regras do Negócio, do Modelo de Atores e Recursos e do Modelo de Conceitos.

Os passos serão os mesmos que proporcionam desenvolver a Gestão do Conhecimento, embasadas conceitualmente e codificadas através da Enterprise Knowledge Development (EKD).

Nesse sentido, Saxena (2004) ao apresentar sugestões para as mudanças na Gestão da Administração Pública afirma ser necessário:

- Conhecimento do processo - identificação dos processos organizacionais, seus objetivos e definição de seus limites, interfaces, principais inputs e outputs, departamentos que executam cada um destes processos, os usuários (internos e externos) que se beneficiam pelos mesmos e os fornecedores que produzem os inputs;

- Redesenho de processo - Agora deve se modelar os processos selecionados em detalhes, com uma representação gráfica dos mesmos. Será feita uma análise para apontar suas fraquezas e problemas, baseada na identificação e mensuração de seu desempenho, através de indicadores.

\subsubsection{Processo 1 - Planejamento de cardápios}

O que dispara todo o processo para aquisição dos gêneros alimentícios, é a definição de um cardápio, balanceado, elaborado por nutricionistas e que, atenda ao mínimo estipulado por refeição, que é de $15 \%$ das necessidades diárias do beneficiado 
durante o tempo em que este permanece na Unidade Escolar, procurando não onerar em muito o seu custo, pois o repasse para subsidiar esta refeição é de $\mathrm{R} \$ 0,18$ para alunos de creches, R\$ 0,15 para alunos de Educação Pré-Escolar (4 a 6 anos) e alunos da $1^{\text {a a }} 8^{\mathrm{a}}$ série do Ensino Fundamental Municipal e R\$0,21 (somando-se os repasses federal e estadual) para alunos de $1^{\mathrm{a}}$ a $8^{\mathrm{a}}$ série do Ensino Fundamental Estadual.

Para que os cardápios sejam elaborados existe dentre outras, algumas exigências, neste trabalho denominadas Regras do Negócio, a serem respeitadas. Estas, por estarem atreladas a construção do modelo de processos serão aqui citadas mostrando que alguns modelos são desenvolvidos concomitantemente.

Nem sempre um modelo atinge a perfeição numa primeira tentativa de codificação fazendo-se assim necessárias avaliações e reuniões freqüentes para atualizalos.

Regra 1.1.1 O cardápio deve ser elaborado por nutricionistas;

Regra 1.1.2 Deverão ser utilizados $70 \%$ dos produtos considerados básicos pelo FNDE;

Regra 1.1.3 Deverão ser respeitados os costumes alimentícios da população a ser beneficiada;

Regra 1.1.4 Cada refeição deverá ter no mínimo 15\% (quinze por cento) das necessidades diárias dos beneficiados;

Regra 1.1.5 Deverão ser consideradas os per capitas cientificamente definidos, salvo adequações necessárias;

Regra 1.1.6 O custo para cada refeição não poderá ultrapassar em muito o valor do repasse, por aluno, por dia de atendimento;

Regra 1.1.7 Deverá haver adequação ao público a ser atendido, considerando faixa-etária e realidade sócio-econômica.

Atualmente, partindo das regras acima citadas e considerando as condições de infra-estrutura das Unidades e o número de pessoal disponível para o preparo das refeições nas Unidades (merendeiras e serventes-merendeiras), o cardápio é definido pelas nutricionistas. Os cardápios do município de São Carlos são mensais, divididos 
em quatro semanas de atendimento diferenciado e, são semestralmente reavaliados pelos envolvidos.

Em São Carlos, quando do início do novo governo em 2001, não existiam cardápios implantados em nenhum segmento da Alimentação Escolar, no primeiro recesso escolar de jul. 2001, as merendeiras foram reunidas por tipo de atendimento para apresentarem propostas de elaboração de cardápios a partir da prática diária adotada até então.

Após este encontro, as nutricionistas, respeitando os gêneros alimentícios, utilizados e acrescentando uma maior variedade de gêneros perecíveis (hortifrutigranjeiros) e não-perecíveis (biscoitos recheados, farinha de milho, cereal matinal etc.), elaboraram a primeira proposta de cardápios que foi implantada nas Escolas Municipais de Educação Infantil - EMEIs e nas Escolas Municipais de Educação Básica - EMEBs, em ago. 2001.

Em 2002 este mesmo cardápio é reavaliado em reunião com nutricionistas, diretores de escola e merendeiras, sendo posteriormente apresentada a $2^{\mathrm{a}}$ versão do mesmo às Unidades Escolares.

Ainda em 2002 é também implantada uma $1^{\mathrm{a}}$ versão dos cardápios de creches sendo também reavaliado encontrando-se em sua $2^{\mathrm{a}}$ versão.

Em 2003 é realizada mais uma reavaliação de todos os cardápios para o início do ano e também entregue a $1^{\mathrm{a}}$ versão de cardápios para as Escolas Estaduais. Atualmente, todas as Unidades que recebem atendimento da Divisão de Alimentação Escolar têm seu cardápio desenvolvido, entregue e em prática.

Os procedimentos para definição e elaboração dos cardápios são os a seguir citados:

- O cardápio é desenvolvido e apresentado em editor de texto, tem seu valor calórico e custo, calculados manualmente. Após sua definição e, considerando a 
incidência de cada produto, os per capitas adotados e o número de beneficiados em cada uma das Unidades atendidas, é calculada a quantidade de gêneros para cada Unidade utilizando planilhas eletrônicas.

- O resultado dos cálculos é manualmente adequado às embalagens de produtos utilizadas, pois são entregues nos abastecimentos das Unidades Escolares, de preferência, caixas e fardos fechados dos produtos mantidos em estoque na Divisão de Alimentação Escolar (DAE) e finalmente, alimenta-se o programa existente para controle de movimentações do estoque da DAE, considerando as 90 (noventa) Unidades atendidas.

Os dados utilizados para alimentar o sistema (estoque ideal), usam a informação de que cada mês contém quatro semanas, ou seja 20 (vinte) dias, sem considerarem as paralisações de aula, os feriados, etc.

Os abastecimentos são realizados de acordo com os agrupamentos de tipos de gêneros alimentícios utilizados (perecíveis: carnes, hortifrutigranjeiros, pães, leite e derivados e estocáveis ou não-perecíveis), o sistema existente para controle de movimentação de estoque, emite recibos nominais a cada uma das Unidades considerando também os agrupamentos de produtos existentes:

Produtos estocáveis: mensalmente, nos primeiros 10 (dez) dias do mês, com direito a reforço, quando necessário e na época necessária;

\section{Produtos perecíveis:}

- Carnes: semanalmente às segundas-feiras de abastecimento normal;

- Hortifrutigranjeiros: semanalmente às segundas-feiras de abastecimento normal;

- Pães: semanalmente ou quinzenalmente, de acordo com o cardápio adotado;

- Leite in natura: semanalmente ou quinzenalmente, de acordo com o cardápio adotado;

- Bebidas lácteas: quinzenalmente, de acordo com o cardápio adotado; 
Existem atualmente implantados em toda a rede municipal e estadual os tipos de cardápios:

\begin{tabular}{|c|c|c|}
\hline Tipo de Cardápio & Sub-tipos & Atendimento \\
\hline $\begin{array}{l}\text { Cardápio para } \\
\text { creches }\end{array}$ & $\begin{array}{ll}\text { - } & \text { De } 0 \text { a } 1 \text { ano } \\
\text { - } & \text { De } 1 \text { a } 3 \text { anos }\end{array}$ & $\begin{array}{l}\text { - } 14 \text { (quatorze) Creches Municipais; } \\
\text { - } 07 \text { (sete) Creches Filantrópicas. } \\
\text { Crianças de } 0 \text { a } 3 \text { anos. }\end{array}$ \\
\hline $\begin{array}{c}\text { Cardápio para Educação } \\
\text { Pré- Escolar }\end{array}$ & $\begin{array}{ll}\text { - } & \text { Tipo A } \\
\text { - } & \text { Tipo B }\end{array}$ & $\begin{array}{l}\text { - } 28 \text { (vinte e oito) Escolas Municipais de } \\
\text { Educação Infantil - EMEIs. } \\
\text { Crianças de } 4 \text { a } 6 \text { anos. }\end{array}$ \\
\hline $\begin{array}{c}\text { Cardápio para } \\
\text { Ensino Fundamental }\end{array}$ & $\begin{array}{ll}\text { - } & \text { Tipo A } \\
\text { - } & \text { Tipo B } \\
\text { - } & \text { Tipo C } \\
\text { - } & \text { Tipo D }\end{array}$ & $\begin{array}{l}\text { - } \quad 08 \text { (oito) Escolas Municipais de Educação } \\
\text { Básica - EMEBs; } \\
\text { - } \quad 28 \text { (vinte e oito) Escolas Estaduais; } \\
\text { - } \quad 01 \text { (um) APAE São Carlos; } \\
\text { - } \quad 03 \text { (três) SESIs 106, } 108 \text { e } 407 . \\
\text { Crianças de } 7 \text { a } 14 \text { anos. }\end{array}$ \\
\hline $\begin{array}{l}\text { Cardápio para } \\
\text { Projetos }\end{array}$ & - Lanche & $\begin{array}{l}\text { - Unidade do SESI } 407 \\
\text { Crianças de } 7 \text { a } 14 \text { anos. }\end{array}$ \\
\hline
\end{tabular}

Figura 17 - Tipos de cardápios adotados em São Carlos, SP.

Aqui cabem algumas observações quanto a cardápios adotados:

- Considera-se sempre como $1^{\mathrm{a}}$ semana, a $1^{\mathrm{a}}$ semana do mês. Se, eventualmente, o mês tiver 5 (cinco) semanas, a $4^{\mathrm{a}}$ semana será repetida;

- Quando não houver o produto na Unidade a merendeira estará autorizada a fazer a troca do produto por gênero equivalente;

- As refeições são flexíveis dentro da semana, mas suas preparações não podem ser alteradas a fim de garantir o equilíbrio nutricional;
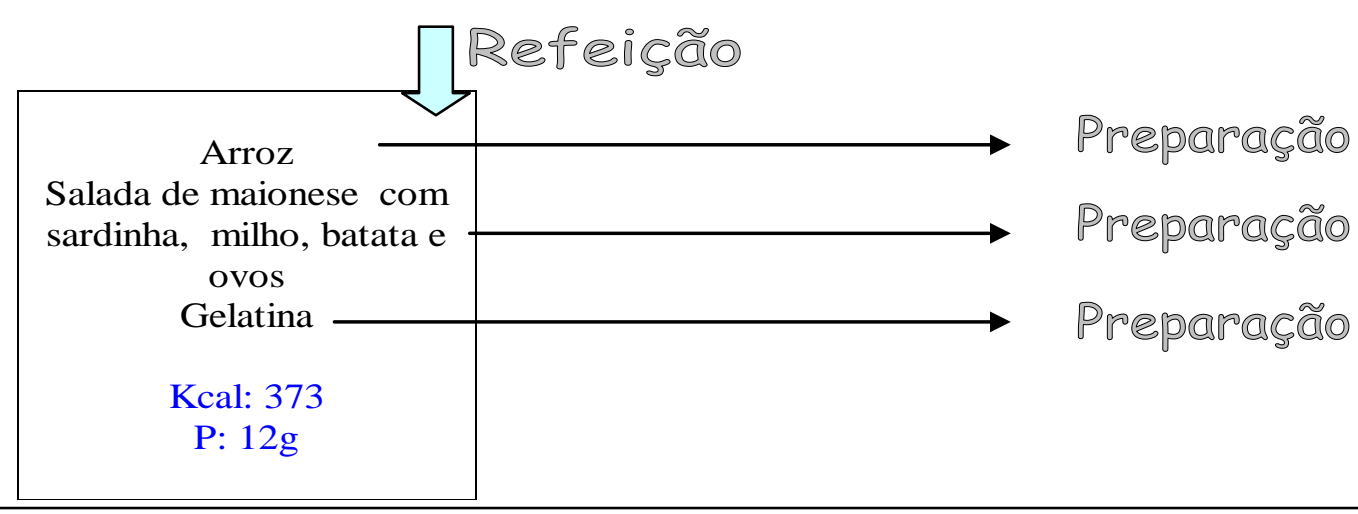

Preparação

Figura 18 - Modelo para o entendimento de refeição e preparação - São Carlos, SP.

Fonte: Divisão de Alimentação Escolar de São Carlos, SP 


\begin{tabular}{|c|c|c|c|c|}
\hline SEGUNDA & TERÇA & QUARTA & QUINTA & SEXTA \\
\hline $\begin{array}{l}\text { Leite com aveia } \\
\text { Biscoito salgado c/ } \\
\text { margarina }\end{array}$ & $\begin{array}{l}\text { Leite com chocolate } \\
1 / 2 \text { pão com geléia }\end{array}$ & $\begin{array}{c}\text { Leite com café } \\
\text { Biscoito salgado com } \\
\text { margarina }\end{array}$ & $\begin{array}{l}\text { Leite com fruta } \\
\text { 1/2 Pão com geléia }\end{array}$ & $\begin{array}{c}\text { Leite com café } \\
\text { Biscoito salgado com } \\
\text { margarina }\end{array}$ \\
\hline Kcal: 207 P:6g & Kcal:246 P:9g & Kcal:209 P:8g & Kcal:297 P:8g & Kcal:264 P:8g \\
\hline $\begin{array}{c}\text { Suco de cenoura com laranja } \\
\qquad \text { Kcal: } 54 \quad \text { P: } 1 \mathrm{~g}\end{array}$ & $\begin{array}{c}\text { Maçã } \\
\text { Kcal: } 52 \quad \text { P:0,5g }\end{array}$ & $\begin{array}{l}\text { Chá de camomila } \\
\text { Kcal:36 P:1g }\end{array}$ & $\begin{array}{l}\text { Banana picada com aveia } \\
\text { Kcal: } 83 \quad \text { P: } 1 \mathrm{~g}\end{array}$ & $\begin{array}{c}\text { Suco de Mamão ou mamão } \\
\text { picado com Neston } \\
\text { Kcal: } 41 \quad \text { P:1g }\end{array}$ \\
\hline $\begin{array}{l}\text { Arroz com molho de frango } \\
\text { desfiado } \\
\text { Salada de cenoura c/ tomate } \\
\text { Suco } \\
\text { Kcal: } 176 \quad \text { P:9g }\end{array}$ & $\begin{array}{l}\text { Macarronada com mini } \\
\text { almôndegas ou molho de } \\
\text { carne moída } \\
\begin{array}{ll}\text { Kcal: } 150 & \text { P:9g }\end{array}\end{array}$ & $\begin{array}{l}\text { Arroz, feijão, carne picada } \\
\text { com batata e repolho } \\
\text { Kcal: } 267 \text { P: } 12 \mathrm{~g}\end{array}$ & $\begin{array}{c}\text { Arroz, hambúrguer de } \\
\text { carne moída, creme de } \\
\text { cenoura } \\
\text { Salada de beterraba } \\
\text { Kcal: } 162 \quad \text { P:9g }\end{array}$ & $\begin{array}{l}\text { Arroz temperado com carne } \\
\text { desfiada, milho, ervilha e } \\
\text { ovo cozido } \\
\text { Kcal: } 194 \quad \text { P: } 11 \mathrm{~g}\end{array}$ \\
\hline $\begin{array}{l}\text { Iogurte de morango } \\
\text { Biscoito salgado } \\
\begin{array}{ll}\text { Kcal: } 214 & \text { P:8g }\end{array}\end{array}$ & $\begin{array}{l}\text { Leite com aveia } \\
\text { Biscoito salgado } \\
\text { Kcal: } 207 \quad \text { P:7g }\end{array}$ & $\begin{array}{c}\text { Leite com açúcar queimado } \\
\text { Bolo } \\
\text { Kcal: } 198 \quad \text { P:11g }\end{array}$ & $\begin{array}{l}\text { Leite com chocolate } \\
\text { e maisena } \\
\text { Kcal: } 174 \quad \text { P:6g }\end{array}$ & $\begin{array}{c}\text { Chá mate } \\
\text { Biscoito recheado } \\
\text { morango } \\
\text { Kcal: } 126 \text { P:2g }\end{array}$ \\
\hline $\begin{array}{c}\text { Arroz, feijão } \\
\text { Purê de batata com salsicha } \\
\text { picada } \\
\text { Kcal:176 P:11, g }\end{array}$ & $\begin{array}{l}\text { Polenta com molho de } \\
\text { sardinha } \\
\text { Kcal: } 187 \quad \text { P:5g }\end{array}$ & $\begin{array}{c}1 / 2 \text { cachorro quente } \\
\text { Gelatina } \\
\text { Suco } \\
\text { Kcal:229 P: } 10 \mathrm{~g}\end{array}$ & $\begin{array}{l}\text { Sopa de feijão com } \\
\text { macarrão, legumes e } \\
\text { mandioca } \\
\text { Kcal:105 P:2g }\end{array}$ & $\begin{array}{l}\text { Macarrão de forno com } \\
\text { frango desfiado, ervilha, } \\
\text { milho e maionese } \\
\text { Biscoito doce } \\
\text { Kcal: } 278 \quad \text { P:7g }\end{array}$ \\
\hline
\end{tabular}

Figura 19 - Modelo da $1^{\text {a }}$ semana do cardápio de creches 2 a 3 anos - São Carlos, SP.

Fonte: Divisão de Alimentação Escolar de São Carlos, SP

Definidos os cardápios, é necessária, administrativamente, a realização dos cálculos dos gastos previstos tanto para os gêneros alimentícios, quanto para os recursos financeiros, pois estes definem os tipos de aquisições a serem realizadas.

Outros procedimentos a serem adotados após a elaboração dos cardápios são: a documentação dos mesmos, sua reprodução e sua distribuição para as Unidades atendidas.

Para documentar os cardápios é utilizado o editor de texto utilizando tabelas representando os tipos de refeições por dia de atendimento. Após codificado, o cardápio é impresso e reproduzido de acordo com a quantidade de Unidades por tipo de cardápio elaborado para cada tipo de atendimento. 
A distribuição dos cardápios é realizada basicamente de duas maneiras:

- São realizadas reuniões com os responsáveis pelas Unidades Escolares para que ocorram a entrega dos cardápios e sejam realizados possíveis esclarecimentos;

- São encaminhados através dos veículos da Divisão de Alimentação Escolar para as Unidades atendidas e, acompanhados por protocolo de recebimento que deve ser assinado pelo responsável pela Unidade.

Para a modelagem do processo - Planejamento de Cardápios, os modelos utilizados são:

- Modelo de objetivos (MO);

- Modelo de Regras do Negócio (MRN);

- Modelo de Processos do Negócio (MPN);

- Modelo de relacionamento entre os modelos anteriormente citados. 


\subsection{Modelagem de relacionamento do processo elaborar cardápios}

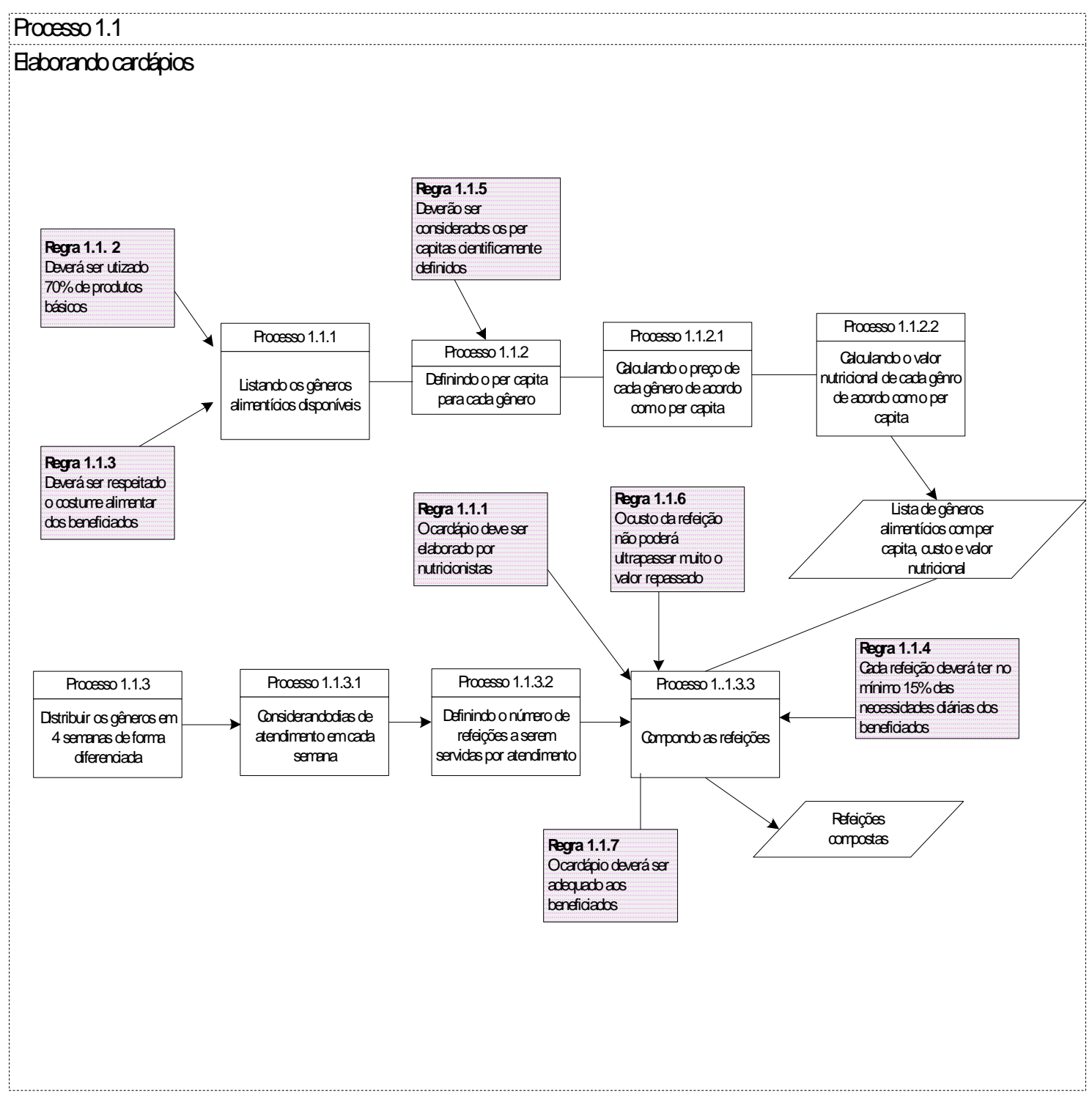

Figura 20 - Modelo de relacionamento para o Processo 1.1 - Elaborar cardápios Fonte: elaborado pela autora 


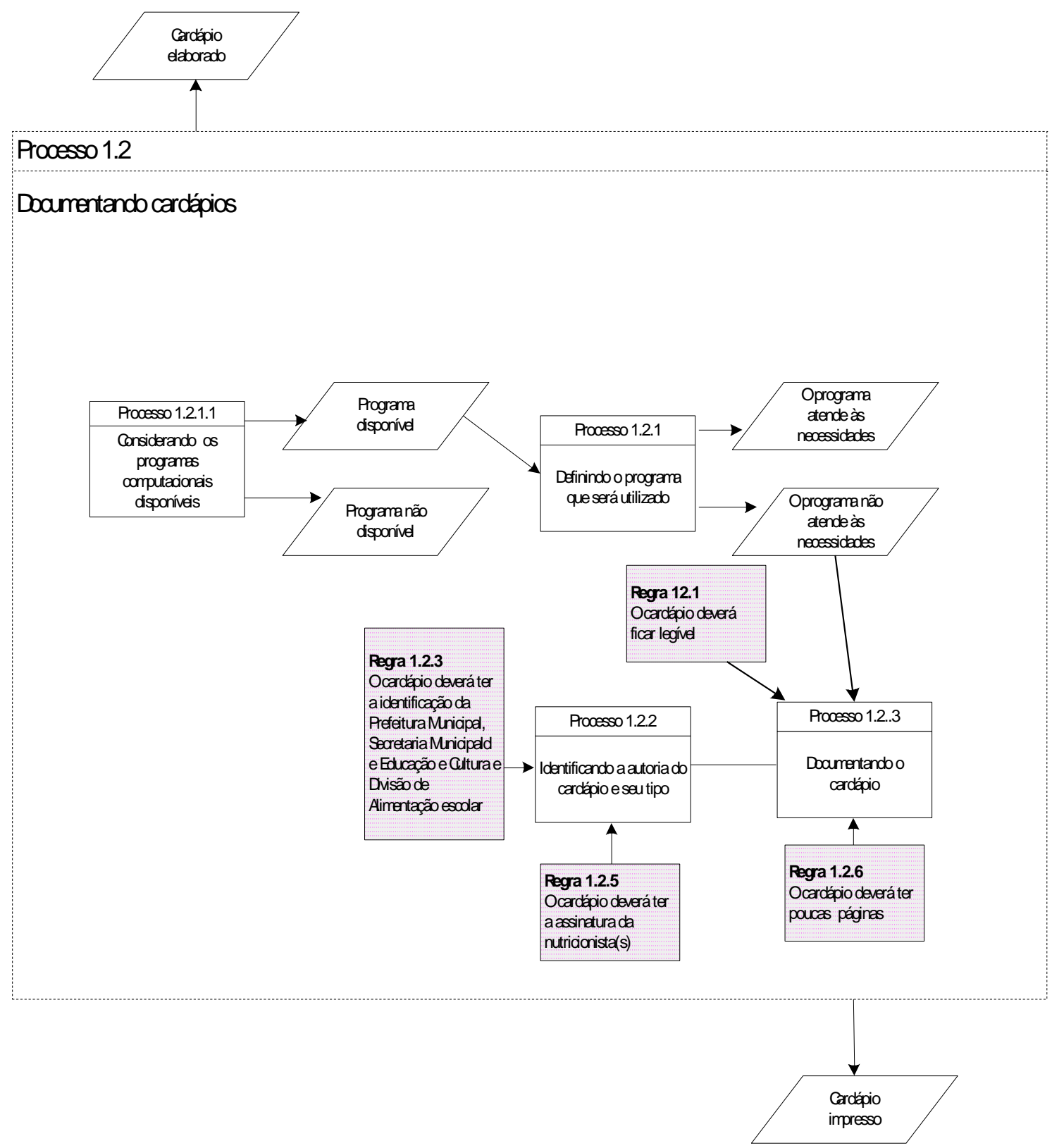

Figura 21 - Modelo de relacionamento para o Processo 1.2 - Documentar cardápios Fonte: elaborado pela autora 


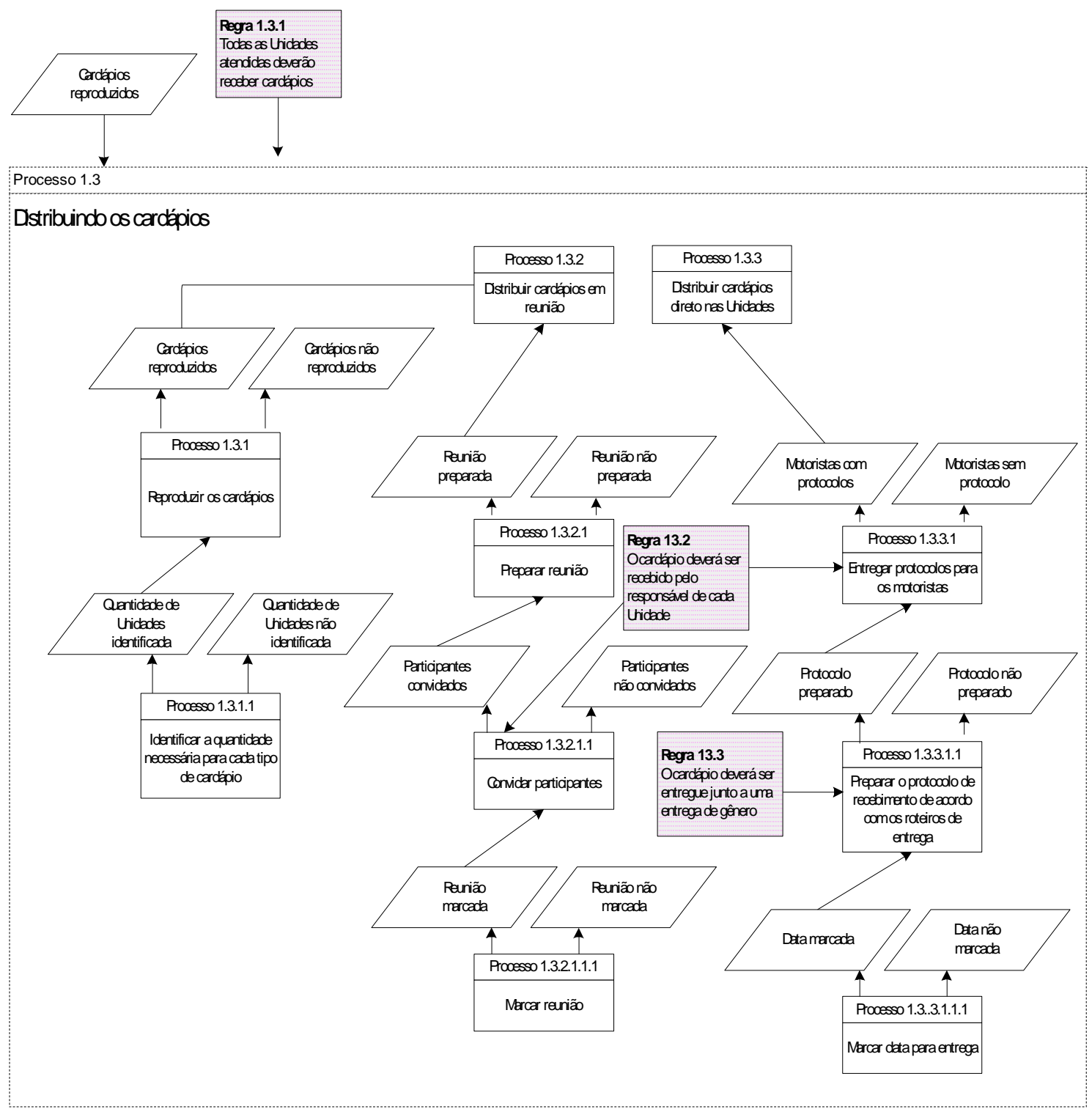

Figura 22 - Modelo de relacionamento para o Processo 1.3 - Distribuir cardápios Fonte: elaborado pela autora

Neste Modelo, em especial, com o objetivo de fornecer informações para controle da execução do Programa, devem ser apresentadas inicialmente as legislações pertinentes ao desenvolvimento de cardápios, bem como informações sobre aspectos nutricionais dos mesmos, promovendo um encontro para discussão, questionamentos e respostas entre os profissionais do setor. Os profissionais que dominam o assunto se disponibilizariam para responder aos questionamentos. 


\subsubsection{Processo 2 - Aquisição dos gêneros}

O processo de aquisição de gêneros para a Alimentação Escolar no município de São Carlos, SP é feito em média a cada 6 a 8 meses, por Contrato, Compra Direta, Convite de Preços, Tomada de Preços ou Concorrência Pública, de acordo com cada caso, respeitando a legislação existente.

Quando uma nova aquisição de gêneros precisa ser feita, consideram-se:

- Quantidade do gênero em estoque;

- Características físicas de cada gênero;

- Calendário escolar adotado;

- Disponibilidade de tempo até o recebimento dos gêneros;

- Escolha da modalidade de licitação;

- Levantamento de demanda dentro do limite financeiro da modalidade de licitação;

- Limite de validade dos gêneros;

- Espaço disponível ao armazenamento de produtos na Divisão de Alimentação;

- Condições de entrega, prazos, quantidades para entrega e endereço de Unidades, etc

- Encaminhamento de Requisição de Material, com quantitativo de todos os itens, descrição detalhada das especificações de cada item;

- Realização de teste de aceitabilidade e degustação em marcas desconhecidas;

- Para os hortifrutigranjeiros considera-se a sazonalidade do gênero devido à variação de preço existente.

Feita e encaminhada a requisição de compras dos alimentos, a Comissão Permanente de Licitação edita, publica e acompanha o processo de licitação que deverá respeitar o disposto na Lei 8.666 de 21/06/93 e suas alterações que prevê as modalidades de licitação e rege os termos de contrato a ser assinado entre Contratada e Contratante. 


\subsubsection{Processo 3 - Recebimento e armazenamento dos gêneros.}

$\mathrm{Na}$ Divisão de Alimentação Escolar os produtos estão classificados em perecíveis e não perecíveis, decorrente dos tipos de processos de licitação e decorrente da forma de distribuição, entre outros.

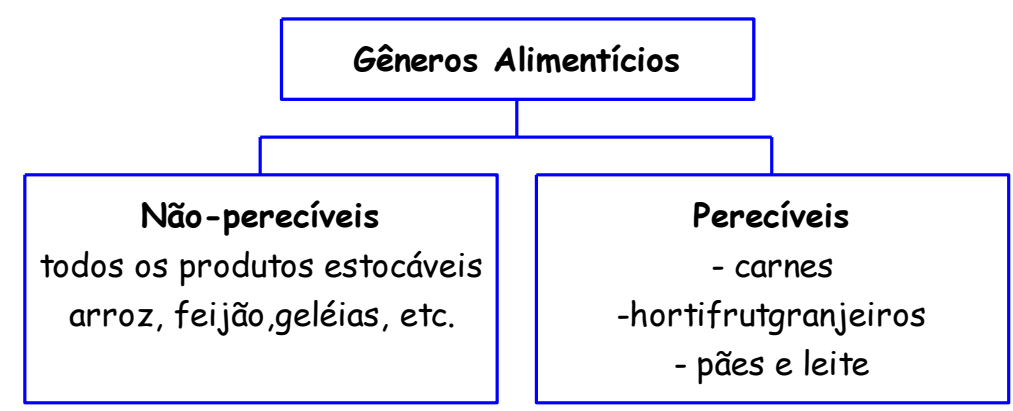

Figura 23 - Classificação dos gêneros utilizados na alimentação escolar em São Carlos, SP

Realizados os processos de licitação, os pedidos são feitos aos fornecedores como descritos a seguir:

\section{Gêneros perecíveis}

$\mathrm{O}$ pedido dos perecíveis é feito semanalmente às quartas-feiras, levando-se em consideração alterações de quantidades feitas pelas Unidades Escolares durante a semana que antecede o pedido.

O recebimento é feito semanalmente às segundas feiras a partir das 7:30h na Divisão de Alimentação Escolar, onde é submetido à avaliação das nutricionistas quanto à qualidade que apresentam e, também, são realizadas conferências por amostragem no peso das embalagens, logo em seguida, os itens recebidos passam a ser distribuídos às 90 Unidades Escolares atendidas.

Este procedimento é válido para as carnes e os hortifrutigranjeiros. O recebimento de pães e leite é realizado diretamente nas Unidades Escolares e são entregues pelos próprios fornecedores. 


\section{Gêneros estocáveis}

O pedido é efetuado de acordo com o especificado em edital de licitações ou de acordo com a necessidade da Divisão de Alimentação Escolar, através de envio de fax.

Quando chegam na Divisão de Alimentação Escolar são avaliados pelas nutricionistas que verificam as marcas, condições das embalagens, datas de validade, etc.. Se tudo estiver de acordo com a compra os gêneros são descarregados e armazenados dos armazéns da Divisão de Alimentação Escolar (DAE).

Para que esses gêneros sejam armazenados é utilizado um layout dos armazéns contendo desenhos dos pallets de proteção necessários (estrados de madeira utilizados para evitar o contato do gênero com o chão), onde por aproximação ao volume previsto, estes gêneros têm seus lugares definidos.

Portanto, quando se recebem gêneros na DAE é necessário:

- $\quad$ adequar espaço de armazenamento

- $\quad$ verificar datas de validade, embalagens, de acordo com Edital publicado;

- $\quad$ arrumar os gêneros em pilhas que facilitem sua amarração e contagem;

- $\quad$ verificar dados da Nota Fiscal;

- dar entrada dos gêneros no sistema informatizado de controle de estoques;

- dar recebimento e aceite na Nota Fiscal e encaminha-la para pagamento.

\subsubsection{Processo 4 - Distribuição dos gêneros}

A distribuição dos gêneros também ocorre de maneira diferenciada para cada tipo de gênero alimentício em decorrência de sua perecividade, forma de entrega, registro de entrada e saída no sistema de controle de estoque, etc.

\section{Perecíveis:}

Os gêneros perecíveis são entregues semanalmente e, os passos considerados, são basicamente os mesmos citados para os estocáveis, sendo que as Unidades informam via telefone a solicitação por aumento, diminuição ou cancelamento da 
próxima entrega, às quartas-feiras que antecedem a entrega propriamente dita, até às 12:00 horas, para que essa informação seja repassada ao fornecedor. O abastecimento seguinte é feito na segunda-feira.

Os perecíveis carnes têm a entrada incluída no sistema a partir da Nota Fiscal do fornecedor. No sistema para controle de estoque, são digitados, incluídos como movimentações e impressos em três vias, os recibos que correspondem aos gêneros que a Unidade irá receber. O processo para digitação dos produtos é realizado antes da entrada da nota que prevê no sistema a real data da entrega, ficando para este dia as tarefas de entrada da nota para que num mesmo dia tenhamos entrada e saída de gêneros sem causar quantidades negativas no estoque.

Os recibos são emitidos pelo sistema, mas saem com a data da impressão, sendo necessárias anotações à mão sobre a data e horário da entrega.

As quantidades definidas são flexíveis, podendo a unidade solicitar alterações na semana anterior ao da entrega. Junto aos recibos com o roteiro de entrega, é também disponibilizada uma planilha em excel com o montante geral da carga.

O procedimento para entrega é o mesmo adotado para os gêneros estocáveis incluindo também o sistema de recibos em três vias. É realizada apenas uma entrega na semana.

As entregas são realizadas às segundas-feiras geralmente a partir das $9 \mathrm{~h}$ e $30 \mathrm{~min}$. até as 17:00 horas, descontando-se $1 \mathrm{~h}$ e $30 \mathrm{~min}$. para almoço, nos roteiros da parte urbana da cidade e às terças-feiras apenas na parte da manhã, para a parte rural da cidade. Isto quando tudo ocorre dentro da normalidade.

Os veículos utilizados para as entregas são os veículos da frota da Divisão de Alimentação. 
Os perecíveis hortifrutigranjeiros: têm quantidades definidas que são flexíveis, podendo a unidade solicitar alterações na semana anterior ao da entrega.

Esta entrega é realizada pelo fornecedor que, utiliza-se de dois veículos para as entregas urbanas e, deixa na Divisão os gêneros referentes às unidades rurais.

Às quartas-feiras que antecedem as entregas, é encaminhado via e-mail, o pedido ao fornecedor tratando-se de três planilhas excel: roteiro urbano I, roteiro urbano II e roteiro rural com as unidades definidas em ordem de entrega e contento, todos os gêneros e suas respectivas quantidades.

Os recibos são emitidos também em três vias, pela Divisão de Alimentação e, entregues para os fornecedores às segundas-feiras. Neste caso os procedimentos e a questão sobre as anotações de data e horário, correspondem aos adotados para as carnes. Junto a cada veículo do fornecedor vai um funcionário da Divisão para acompanhar as entregas que vão geralmente das 10:00 horas até as 17:00 horas, sem parada para almoço. É realizada apenas uma entrega na semana.

A entrada e saída de mercadoria no sistema são realizadas da mesma forma que as carnes;

Os perecíveis pães: têm quantidades definidas que são flexíveis, podendo a unidade solicitar alterações na semana anterior ao da entrega.

O pedido é realizado também às quartas-feiras através de envio de uma planilha excel contendo as unidades e suas respectivas quantidades, via fax.

Esta entrega é realizada pelo fornecedor que, utiliza-se de veículos próprios para as entregas urbanas e, deixa na Divisão os gêneros referentes às unidades rurais.

Toda a sexta-feira, quando realiza a entrega da Nota fiscal referente às entregas da semana, o fornecedor retira na Divisão de Alimentação os recibos em três vias referentes às entregas da semana seguinte, acompanhados de uma planilha excel com o montante total da previsão de entrega para a semana. 
Como são realizadas, de acordo com o cardápio, algumas unidades recebem mais que uma entrega na semana, sendo o registro de saída no sistema, realizado com a quantidade total da semana e considerando a data da última entrega da semana. Para o fornecedor a data constante impressa no recibo é a data de emissão do mesmo, podendo conter portanto alguns recibos com mais que uma assinatura, referente a cada entrega realizada. Este procedimento é adotado para que o sistema não apresente por muito tempo quantidades negativas em estoque, pois a entrada dos gêneros se dá após sua entrega através do registro da Nota fiscal.

Os demais procedimentos para emissão de recibos pela Divisão são idênticos aos utilizados para as carnes e hortifrutigranjeiros;

Os perecíveis leite e derivados: têm quantidades definidas que são flexíveis, podendo a unidade solicitar alterações na semana anterior ao da entrega.

Às quartas-feiras que antecedem as entregas é encaminhado, via e-mail, o pedido ao fornecedor através de uma planilha excel com as unidades e suas respectivas quantidades de entregas de toda a semana.

Esta entrega é realizada pelo fornecedor que, utiliza-se de veículos próprios. O leite in natura é entregue semanalmente, sendo em alguns casos, em decorrência do tipo de atendimento e cardápio entregue mais que uma vez na semana.

As bebidas lácteas são entregues quinzenalmente, de uma só vez.

No sistema o procedimento para emissão dos recibos respeita o mesmo adotado para os pães, respeitando as datas reais de entrega, sendo a data de emissão diferente destas.

Neste caso, o fornecedor realiza suas entregas com recibos próprios para cada entrega, em duas vias ficando uma na Unidade escolar e outra na Divisão de Alimentação. Portanto existe a necessidade de que, depois de entregues na DAE os recibos do fornecedor estes, sejam anexados aos recibos emitidos pelo sistema da 
Divisão em duas vias, ficando alguns recibos da Divisão (quantidade total da semana) com mais que um recibo do fornecedor (quantidade por entrega na semana). Ocorre também que por receber apenas uma via, a Divisão anexa esta no recibo da pasta da escola, ficando a caixa do tribunal sem os recibos com assinaturas.

Todo esse procedimento é necessário porque foram solicitadas pelo Tribunal de Contas que, as saídas de gêneros, sejam elas quais forem deverão ser feitas individualmente no sistema (setembro/2002), pois anteriormente, dava-se entrada dos gêneros pela Nota Fiscal, os recibos eram diversos, agrupados e, sua soma era registrada como uma única saída total, ficando o sistema sem poder informar quanto da entrada foi direcionada para cada uma das unidades atendidas. Essa informação ficava disponível apenas nos arquivos de impressos.

\section{Estocáveis}

A partir das quantidades calculadas e definidas como necessárias para que cada unidade passe um mês, e do Relatório de Estoque que cada unidade encaminha para a Divisão de Alimentação na última segunda-feira de cada mês informando entre outras coisas, o estoque real existente na unidade e os roteiros utilizados na logística de abastecimento e distribuição. A nutricionista realiza análise nos relatórios, anotando manualmente as quantidades que serão encaminhadas às Unidades, respeitando as embalagens fechadas e, em seguida o auxiliar administrativo digita no sistema de controle de estoque o recibo decorrente de cada uma das 90 operações de saída de produtos do estoque da Divisão.

Em mãos dos recibos digitados são preparados "esquemas" de distribuição que nada mais são do que a soma de todos os produtos de todas as unidades pertencentes a uma determinada carga de uma determinada região do município, a existência deste esquema busca facilitar o carregamento, pois um determinado produto é carregado apenas uma vez na DAE e porcionado na Unidade Escolar. 
Quando chegam na unidade, a entrega é realizada e conferida por responsável da unidade, sendo também informados: data, horário e quem realizou a entrega. $\mathrm{O}$ recibo correspondente a cada entrega é impresso em três vias sendo:

- $1^{\text {a }}$ via arquivada na pasta da unidade escolar, existente na Divisão de Alimentação, em ordem alfabética;

- $2^{\text {a }}$ via arquivada na caixa do Tribunal de contas, existente na Divisão, em ordem numérica de saída;

- $\quad 3^{\text {a }}$ via arquivada na unidade escolar.

Sendo os cardápios mensais, considerando quatro semanas diferentes para completá-los. Os gêneros não-perecíveis são entregues às Unidades Escolares uma única vez, no início de cada mês, podendo ser solicitado um reforço de gêneros, se necessário, originando desta forma, um estoque distinto em cada Unidade Escolar.

Os veículos utilizados para as entregas são os veículos da frota da Divisão de Alimentação que se constitui de:

- 1 (um) furgão Chevrolet D-40, com capacidade para 3.000kg de carga;

- 2 (duas) kombis Wolkswagem

Para enriquecimento das informações acima citadas e, para que as mesmas sejam desenvolvidas corretamente, há a necessidade da inserção de outros conceitos como boas práticas a serem respeitadas quando das entregas nas Unidades por parte dos profissionais da DAE, conhecimentos sobre a legislação das condições higiênicosanitárias dos veículos a serem utilizados, exercícios para se evitarem lesões e acidentes durante as entregas, entre outras.

Tais informações poderiam ser apresentadas em seminários preparados pelos próprios profissionais a partir da escola de um dos temas ou convidando-se profissionais para falar sobre eles. 


\subsubsection{Processo 5 - Acompanhamento do preparo e consumo nas Unidades Escolares}

Atualmente esse é o processo mais deficiente dentro da Divisão de Alimentação, pois são várias as limitações para a viabilização do mesmo.

A Divisão, como já fora citado, é responsável pela alimentação de diversos setores envolvidos com a educação. Na educação municipal existe a questão da subordinação à mesma secretaria e, portanto ao mesmo responsável. As atividades no sentido de acompanhamento, controle e fiscalização são de certa maneira mais respeitadas, em decorrência da possibilidade de sua detecção, bem como, de sua orientação e se necessária penalização.

Nas Escolas Estaduais e outras Entidades, fica bastante prejudicado o sistema de controle pois, sem subordinação hierárquica aos setores municipais, algumas providências a serem tomadas, colocam os técnicos da DAE em situações bastante delicadas.

Dentro de cada unidade o responsável maior é o diretor e, são direcionadas a estes todas as orientações referentes à alimentação devido à possibilidade de sua ausência na unidade escolar por alguns momentos. Muitas vezes as orientações não são retransmitidas como se espera às maiores envolvidas, às serventes-merendeiras, sendo importante e necessário um acompanhamento mais pontual.

A Divisão atualmente dispõe de apenas duas nutricionistas para realizar tal acompanhamento que ficam, na maioria do tempo, envolvidas com cardápios, definição de quantidades, pedido para fornecedores, emissão e conferência de recibos, etc. Sobrando pouco tempo ou quase nenhum para as visitas.

Outra limitação encontra-se na falta de veículo disponível para que tais visitas sejam realizadas. Quando em urgências, as visitas são realizadas com veículos próprios das profissionais sem qualquer ajuda de custo. Os veículos da Divisão ficam envolvidos nos serviços de entregas, retiradas de embalagens vazias de gêneros das Unidades, etc. 
Além das condições acima, os profissionais encarregados pelas entregas, por não terem informações suficientes sobre o funcionamento de todos os processos reconhecendo seu verdadeiro papel e como agir, acabam por não terem condições de auxiliarem no controle propriamente dito, o que nesta situação torna-se lastimável, pois os mesmos estão semanalmente, às vezes, por mais de uma vez, em todas as Unidades atendidas.

\subsubsection{Etapa 5 - Desenvolvimento do modelo de atores e recursos}

Antes de aplicar os conceitos propriamente ditos da Enterprise Knowledge Development (EKD), é necessário, para o caso ilustrativo: o setor de Alimentação Escolar do município de São Carlos, considerar uma particularidade quanto aos atores, pois nesta prefeitura a ocupação de cargos dá-se através de Concurso Público, para os quais existe previamente definido o cargo e a função a ser desempenhados.

Com uma pesquisa junto à Secretaria Municipal de Administração é possível identificar para o quadro funcional do setor em questão:

- SERVIÇOS GERAIS (Ajudante de carregamento/Ajudante de limpeza): Carregar materiais, abrir valetas, assentar guias, espalhar pedras; providenciar a limpeza e conservação das áreas internas e externas dos próprios municipais; executar tarefas de limpeza da cidade em ocorrência de urgência; pequenos reparos; alimentar animais; auxiliar na campanha de vacinação de animais; e, outras atribuições que lhe forem determinadas pelos superiores.

- BRAÇAL (Ajudante de carregamento) - Executar: tarefa de limpeza da cidade, entrega de avisos, carpinação de ruas, podas de árvores, abrir valetas e galerias, assentamento de guias e pedras, carga e descarga de mercadorias, tarefa de vigilância e porteiro, limpeza e conservação das áreas internas e externas dos prédios municipais, alimentação e vacinação de animais.

- SERVENTE MERENDEIRA (Ajudante de limpeza): Contribuir para a elaboração do cardápio escolar, preparar e servir merenda, limpar e lavar 
utensílios e dependências da cozinha; efetuar a previsão de gêneros necessários, controlando o estoque, requisitando, recebendo, conferindo e armazenando adequadamente os gêneros alimentícios, efetuar a limpeza das demais dependências da escola, participar de atividades relacionadas à capacitação promovida pela unidade escolar ou Secretaria da Educação. Executar outras tarefas de mesma natureza e nível de dificuldade.

- AUXILIAR ADMINISTRATIVO: Executar atividades administrativas pertinentes à área de atuação; atender ao telefone e ao público em geral; fazer agendamento; controlar entrada e saída de documentos e processos; atualizar cadastros e sistemas; organizar e manter arquivo de documentos; redigir; digitar; efetuar cálculos simples; manter registro e controle do patrimônio e dos materiais necessários à Unidade, executar demais tarefas de processos administrativos.

- MOTORISTA: Dirigir veículos automotores, de acordo com as regras de trânsito e instruções recebidas para efetuar o transporte de passageiros, cargas, mercadorias e animais; inspecionar os veículos automotores, verificando os níveis de combustível, óleo, água, estado de funcionamento dos pneus para providenciar o abastecimento e reparos necessários; examinar as ordens de serviço, verificando o itinerário a ser seguido, os horários, o número de viagens e outras instruções para programar a sua tarefa; zelar pelo veículo e pelo bom andamento do transporte, adotando as medidas cabíveis na prevenção ou solução de qualquer anomalia para garantir a segurança dos serviços prestados aos transeuntes e veículos; providenciar os serviços de manutenção, comunicando falhas e solicitando reparos para assegurar seu perfeito estado; recolher o veículo após a jornada de trabalho, conduzindo-o à garagem da empresa, para permitir sua guarda, manutenção e abastecimento. Entregar e receber cargas, apresentando relatório de entrega. Efetuar reparos de emergência. Auxiliar no carregamento e descarga de materiais dos veículos; executar tarefas afins.

- NUTRICIONISTA: Planejar, coordenar e supervisionar serviços e programas de nutrição analisando carências alimentares e o conveniente aproveitamento dos 
recursos dietéticos, controlando a estocagem, preparação, conservação e distribuição dos alimentos. Executar outras tarefas de mesma natureza e nível de dificuldade.

- APRENDIZ: Entrega e coleta de correspondências, papéis, documentos e processos; registro de entrada, saída e controle de documentos e processos; reprografia de documentos e controle numérico de cópias tiradas; digitação de cartas, ofícios, memorandos e alimentação de base de dados; atendimento ao público; atendimento de telefone, repasse de chamadas e ligações internas e externas.

Portanto é aqui proposta uma atividade-extra a fim de tornar público ao conhecimento de todos, as funções desempenhadas por cada um dos integrantes da equipe, bem como conhecimentos da vida em particular de cada um: formação, família, lazer, outras ocupações, aspirações, etc. Podendo isto ser feito, de acordo com a escolha da maioria, através de um depoimento espontâneo ou leitura de um texto elaborado pelo próprio integrante, seguindo desta forma:

A - O conceito cargos e funções será apresentado a todos os profissionais do setor de forma verbal pela pessoa responsável por dirigir e orientar as atividades;

B - A cada um, será disponibilizado documentalmente, a lista de cargos e funções existente;

C - O documento disponibilizado será levado pelos profissionais ficando a critério dos mesmos a apresentação sobre as informações particulares;

D - Um novo encontro é marcado para que cada membro da equipe possa socializar suas informações.

Após tal procedimento será identificado nos Modelos de Processo do Negócio, a identificação das responsabilidades de cada ator e quais os recursos alocados para a execução da atividade. 


\subsubsection{Etapa 6 - Desenvolvimento do modelo de regras do negócio}

Após ou concomitante à construção do Modelo de Processos do Negócio, tornase possível identificar as regras que levam a execução das atividades, sejam elas de origem legal ou de origem de execução.

Podem sem respeitados os passos que exploram os conceitos e pressupostos da Gestão do Conhecimento e posteriormente a metodologia Enterprise Knowledge Development (EKD) para conceituar regras e codificar informações através da construção do Modelo, que neste caso, insere-se através de relacionamentos aos demais modelos, principalmente ao de Processos do Negócio.

Esta orientação torna-se aplicável também para o modelo a seguir:

\subsubsection{Etapa 7 - Desenvolvimento do modelo de conceitos.}

Mais uma vez, informa-se que o Modelo de Requisitos e Componentes Técnicos, não será considerado para este trabalho, pois abordaria o tema: Tecnologia de Informação e Comunicação, também fator crítico de sucesso à aplicação da Gestão do Conhecimento, mas que foge ao objetivo inicial.

\subsection{Considerações finais}

O presente capítulo procurou atender ao objetivo proposto por este trabalho: Propor um método de trabalho que, utilizando como referencial os modelos da Enterprise Knowledge Development (EKD), desenvolva-os através das atividades da Gestão do Conhecimento, utilizando informações do setor de Alimentação Escolar do município de São Carlos, SP.

No capítulo seguinte serão apresentadas as discussões dos resultados da pesquisa e conclusões cabíveis, incluindo recomendações para o desenvolvimento de trabalhos futuros. 


\section{CONCLUSÕES}

A realização do presente trabalho proporcionou uma forma de aquisição de conhecimentos dos quais são possíveis, neste momento, apresentar algumas conclusões.

A Gestão do conhecimento tem sido bastante difundida nos meios acadêmicos e principalmente empresariais, talvez pelo fato de se perceber, nos últimos anos, a valorização de empresas que trabalham praticamente com a utilização do conhecimento de seus profissionais.

Este fato ocorre com algumas empresas que obtem valores de mercado muito maiores do que aqueles representados pelos seus ativos tangíveis (instalações prediais, infra estrutura, etc.).

A gestão do conhecimento tem sido defendida por uma corrente de pensadores, de maneira positivista, como um caminho para que as empresas superem as dificuldades atuais enfrentadas pelas condições macro-econômica na qual se encontram.

Os mais críticos encaram a gestão do conhecimento como meio para que as empresas se apossem dos conhecimentos de seus profissionais tornando estes um recurso dispensável.

Neste trabalho, segue-se a corrente positivista, pois acredita-se que um ambiente no qual se aplica a gestão do conhecimento tem muito mais a oferecer a seus funcionários do que aquele que é administrado no modelo hierárquico burocrático. A necessidade de convivência e aprendizado é intrínseca ao ser humano, portanto se esta é 
proporcionada no ambiente de trabalho, possibilita o crescimento do profissional e conseqüentemente da empresa na qual ele se encontra inserido.

Neste contexto, a metodologia de modelagem organizacional Enterprise Knowledge Development (EKD), se aplicada respeitando-se as etapas propostas pelos seus idealizadores e proporcionando a prática da gestão do conhecimento: uma lacuna constante encontrada nas publicações sobre o assunto.

Um dos primeiros passos para a aplicação da Enterprise Knowledge Development (EKD), pauta-se no domínio da metodologia por um indivíduo que, para conquistar os possíveis envolvidos com o projeto de modelagem, deve dividir seu domínio de conhecimento com os demais, buscando o entendimento de todos, para que possam colaborar e se comprometerem com o projeto.

A equipe que participará no desenvolvimento da metodologia, poderá se submetida a entrevistas a fim de identificar, crenças, valores, preconceitos existentes em cada um dos envolvidos, sendo possível avaliar os por quês de seus posicionamentos.

É também sugerido que sejam escolhidos profissionais dos mais diversos setores e domínios de conhecimentos possíveis dentro da organização.

No Capítulo anterior essa é considerada a primeira atividade a ser desenvolvida pelo método proposto por este trabalho, pois em sua Etapa 1 que compreende: Apresentação dos propósitos da atividade a ser desenvolvida, definição da equipe de trabalho e a metodologia a ser seguida havendo, como fora citada, a socialização, disseminação e a aquisição de conhecimentos.

Com esta atividade atinge-se o primeiro benefício esperado e apresentado no capítulo introdutório deste trabalho: Com a aplicação do método proposto é possível realizar a introdução aos conceitos básicos de Gestão do Conhecimento e da metodologia de modelagem organizacional Enterprise Knowledge Development (EKD) a fim de situar os envolvidos no trabalho a ser realizado. 
Uma primeira reunião é marcada para que se iniciem as modelagens, buscando que todos participem e contribuam com o seu domínio de conhecimento, sendo esboçados os primeiros modelos. Neste acontecimento, muito da gestão do conhecimento já foi desenvolvido sem que fossem aplicadas receitas sistematizadas, às vezes, até mesmo mecanizadas.

Após a reunião, torna-se necessária a documentação do que foi discutido, ocorrendo o que se chama de codificação, sendo que às vezes, para que esta fase do processo aconteça é necessária a aquisição de outros conhecimentos como por exemplo: conhecimento de ferramentas computacionais ou não.

Por fim, é realizada uma reunião para avaliação dos resultados conseguidos e novamente, novas análises, novas modelagens, novas codificações, etc. Criando um ciclo, na verdade, a espiral do conhecimento apresentada por Nonaka e Takeuchi (1997) que aborda os modos de conversão do conhecimento.

No método proposto por este trabalho, cada etapa corresponde ao desenvolvimento de um único Modelo pertencente à Enterprise Knowledge Development (EKD) respeitando-se os passos propostos (A ao F) que são flexíveis para serem totalmente ou parcialmente aplicados.

A liberdade de expressão proporcionada pela Enterprise Knowledge Development (EKD) quando aplicada com este objetivo, respeitando os envolvidos e seus conhecimentos, disparam processos de motivação que por sua vez, proporcionam uma maior criatividade por parte dos mesmos e a flexibilidade da empresa tão necessária nos tempos atuais.

A escolha de um setor da administração pública não ocorreu por acaso. Esses setores, por sua alta escassez de recursos, tornam-se também excelentes laboratórios, pois oferecem oportunidades para a aplicação das mais diversas teorias e tecnologias existentes, que muitas vezes, ficam arquivadas nos meios acadêmicos. Isso só se torna possível se os dirigentes públicos se conscientizam da necessidade de atualização da 
"máquina", das possibilidades de ganhos, ao se tomarem medidas corretas de gerenciamento.

No tocante aos ganhos proporcionados para a Administração Pública pode-se citar indicadores significantes e positivos, conseguido no caso considerado, após quatro anos de uma gestão norteada pelos princípios da Administração Pública que levam à busca pela aplicação do método proposto a fim de garantir sua continuidade.

\section{Legalidade}

Todas as ações desenvolvidas no Setor de Alimentação durante os anos 20012004 são regidas por leis federais, estaduais e municipais. Como exemplo pode-se citar: contratação por Concurso Público de nutricionistas; implantação de cardápios; substituição de produtos industrializados por produtos naturais, incentivando os produtores locais. Adequação do setor conforme legislação sanitária e aquisições de gêneros regidas pela Lei de licitações.

Impessoalidade

Os interesses defendidos pelo setor estão voltados exclusivamente aos beneficiados do Programa de Alimentação Escolar, sendo implantadas práticas para verificação e controle da qualidade dos gêneros adquiridos. Como exemplo de práticas adotadas temos: desenvolvimento de metodologia para testes de aceitabilidade e degustação; aquisição de balanças de precisão para controle de pesos; devolução de gêneros por falta de qualidade assegurando sua reposição em vinte e quatro horas, etc.

\section{Publicidade}

Quanto à publicidade, muitas iniciativas do Setor de Alimentação são veiculadas nos meios de comunicação. Ocorre a realização de dois Concursos de Receitas com consequente publicação de livros distribuídos em todas as Unidade Escolares. São realizadas orientações por escrito quanto a disponibilizar para a comunidade os cardápios, listas de gêneros entregues nas Unidades, etc. A elaboração de Prestação de Contas é realizada juntamente com os membros do Conselho de Alimentação Escolar. 
Ética

O município de São Carlos, ao longo de quatro anos 2001-2004 consegue implantar uma política para reger a execução do Programa de Alimentação Escolar, pois esta encontra-se pautada em diretrizes e procedimentos estipulados coletivamente.

Moralidade

As iniciativas da gestão 2001-2004 no Setor de Alimentação do município de São Carlos, hoje é conhecido de muitas cidades da região e dos órgãos de fiscalizadores do Programa que, através de auditorias, avaliaram-no como modelo a ser seguido.

\section{Eficiência}

A eficiência conseguida resulta da aplicação de diversas técnicas administrativas em busca da qualidade na prestação de serviços oferecidos que envolvem as instalações prediais, a qualidade dos gêneros alimentícios, os Editais usados para as aquisições de gêneros, a valorização das profissionais da alimentação, ente outros.

Considerando as questões de pesquisa que foram apresentadas no capítulo introdutório, bem como os benefícios esperados com a aplicação da Enterprise Knowledge Development (EKD), pode-se concluir:

Quanto às questões levantadas sobre a Geração de conhecimentos: O Setor de Alimentação tem um modelo de negócio claro e internalizado pelos servidores? Por exemplo, os servidores e geral sabem qual é a missão do Setor? E outros elementos, como visão, valores, cargos, funções, objetivos de curto e longo prazo? Os processos do Setor de Alimentação são bem dominados, padronizados?

Obtemos como benefícios a definição clara do modelo de negócio do Setor de Alimentação. A idéia é construir coletivamente elementos básicos como missão, visão, valores, cargos, funções, objetivos de curto e longo prazo, bem como, envidar esforços 
para que o modelo de negócio faça parte da vida dos servidores do Setor e não consista apenas de palavras eloquentes em cartazes.

O método proposto prevê o atendimento às colocações anteriores, através do desenvolvimento das etapas:

\section{Etapa 2 - Desenvolvimento da missão da empresa; \\ Etapa 3 - Desenvolvimento dos objetivos da empresa, de acordo com os conceitos tratados pela metodologia Enterprise Knowledge Development (EKD).}

No tocante às questões, sobre a atividade de codificação de conhecimentos, abordadas: Os processos de trabalho são documentados, de modo que conhecimentos relativos à sua fundamentação e funcionamento não residam apenas nas cabeças de algumas pessoas, o que as torna insubstituíveis e dificulta a realização dessas tarefas por outras pessoas? Os trabalhos feitos nas unidades são acumulados de forma que são facilmente recuperados, viabilizando o reaproveitamento de trabalho sistemático? Os trabalhos realizados pelas pessoas ficam guardados de forma restrita ou, são oferecidos para quem possa aproveitá-los no futuro?

E, considerando os benefícios esperados para a mesma atividade - Codificação de conhecimentos como sendo: a identificação e codificação de processos de negócio: para que os servidores tenham melhor percepção da cadeia de valor que envolve o trabalho deles, bem como servir de ponto de partida para a reinvenção de processos. $\mathrm{O}$ aumento de produtividade com o armazenamento organizado dos documentos produzidos ao longo do tempo onde, as pessoas poderão recuperar com maior facilidade trabalhos que possam ser usados como base para novos produtos. E, finalmente o agrupamento dos conhecimentos cujo objetivo é: que as pessoas consigam encontrar com maior facilidade as respostas para suas perguntas.

Encontramos, no método ora proposto, o desenvolvimento das Etapas a seguir para o atendimento das atividades de Codificação: 


\section{Etapa 4 - Desenvolvimento do modelo de processos do negócio}

- Processo 1 - Planejamento de cardápios;

- Processo 2 - Aquisição dos gêneros;

- Processo 3 - Recebimento e armazenamento dos gêneros;

- Processo 4 - Distribuição dos gêneros;

- Processo 5 - Acompanhamento do preparo e consumo nas Unidades Escolares.

Para a disseminação de conhecimentos, respeitando-se as questões apontadas: O conhecimento das pessoas tidas como mais talentosas e/ou experientes são compartilhados por seus pares ou ficam restritos a elas e vão embora com essas pessoas quando deixam o Setor? Os progressos e problemas enfrentados em processos importantes são compartilhados pelos outros servidores, além daqueles envolvidos no processo?

Considerando os benefícios esperados como sendo: (1) Diminuir a dependência de acesso a informações e conhecimentos das pessoas que os detêm: as informações e conhecimentos deixem cada vez mais de residir somente nas cabeças, gavetas e microcomputadores das pessoas e passem a estar disponíveis para seus colegas; (2) Disseminar experiências obtidas em processos importantes: um processo que gere polêmicas e/ou que demande reflexões relevantes pode gerar muito conhecimento para os envolvidos, independentemente do resultado, ser positivo ou negativo. E essa experiência pode ser transmitida para seus colegas.

Contemplando tais questões e benefícios esperados quanto à disseminação dos conhecimentos, esse método propõe a aplicação das etapas a seguir:

\section{Etapa 5 - Desenvolvimento do modelo de atores e recursos;}

Etapa 6 - Desenvolvimento do modelo de regras do negócio;

Etapa 7 - Desenvolvimento do modelo de conceitos.

Como última atividade da Gestão do Conhecimento: a apropriação do conhecimentos, as questões propostas à reflexão são: É costume ver exposições de novas práticas consideradas inovadoras desenvolvidas e testadas durante execução dos 
trabalhos do Setor? Os melhores trabalhos são identificados e aproveitados pelos colegas, de modo que uma nova forma de executar uma tarefa possa ser usada como referência pelos demais, fazendo-se com que mais pessoas progridam? As pessoas percebem o resultado de seu esforço para que o Setor execute sua missão e alcance seus objetivos?

Nesta situação, para a apropriação do conhecimento, temos como benefícios esperados: O processo de inovação consciente: a partir da preocupação em se criar novos processos, pode-se partir para grupos de trabalho interdisciplinares de forma que seja garantido o grau de diversidade de idéias necessário (não haja paradigmas dominantes) e que tenham como objetivos produzir inovações e formatar os resultados dos esforços dos grupos para que sejam aproveitados por seus pares. Melhorias de processos: novas formas de fazer as coisas podem ser conhecidas e absorvidas pelos servidores do Setor.

A apropriação do conhecimento, no contexto trabalhado, é automática, mas para que os benefícios acima possam ser verificados existe a necessidade da aplicação do método proposto que fica como contribuição deste trabalho e, como sugestão para pesquisas futuras a fim de comprovar sua aplicabilidade e resultados. 


\section{REFERÊNCIAS}

ABRUCIO, F. L. (2004). O impacto do modelo gerencial na administração pública Um breve estudo sobre a experiência internacional recente. 52 p. (Cadernos ENAP; n. 10). Disponível em http://www.enap.gov.br/programas desenvolvimento/ufam/modulo1.htm. Acesso em 25 out.

ANDRADE, E. P. de; TOMAZ, L. G. (2003). A sinergia entre os capitais do conhecimento como forma de gestão:O caso Norway consultoria. In: KRUGLIANSKAS, I.; TERRA, J. C. C. (2003). Gestão do Conhecimento em pequenas e médias emnpresas. Rio de Janeiro: Campus.

BOSELLI LICITAÇÕES S/C Limitada (1999). Lei n. 8666, de 21 de junho de 1993. Regulamenta o art. 37, inciso XXI, da Constituição Federal, institui normas para licitações e contratos da Administração Pública e dá outras providências. Diário Oficial [da] República Federativa do Brasil. Brasília, DF., 21 jn. Disponível em: <http://www.boseli.com.br/leis.htm>. Acesso em: 2 jul. 2003.

BRASIL (1996). Lei n. 9.394, de 20 de dezembro de 1996. Estabelece as diretrizes e bases da educação nacional. Diário Oficial [da] República Federativa do Brasil, Brasília, DF, 20 dez. Disponível em: 〈http://www.mec.gov.br/legis/default.shtm>. Acesso em: 2 jul. 2003.

BRASIL. (2001). Ministério da Educação. Fundo Nacional de Desenvolvimento da Educação. Programa Nacional de Alimentação Escolar. É hora da merenda!.Brasília, DF.

BRASIL.(2003a). Resolução n. 01, de 16 de janeiro de 2003. Estabelecer critérios para o repasse de recursos financeiros, à conta do PNAE, previstos na Medida Provisória n. 2.178-36, de 24 de agosto de 2001. Ministério da Educação, Fundo Nacional de Desenvolvimento da Educação, Brasília, DF. Disponível em: <http://www.fnde.gov.br/programas/pnae/legislacao/res01_16012003.pdf>. Acesso em: 30 abr. 2003.

BRASIL. (2003b). Medida Provisória n. 2.178-36, de 24 de agosto de 2001. Dispõe sobre o repasse de recursos financeiros do programa Nacional de Alimentação Escolar, institui o Programa Dinheiro Direto na Escola. Altera a Lei n. 9.533, de 10 de dezembro de 1997, que dispõe sobre o programa de garntia de renda mínima, institui programas de apoio da União às ações dos estados e Municípios, voltadas para o atendimento educacional e dá outras providências. Disponível <http://www.fnde.gov.br/programas/pnae/legislacao/mp2178 $36 \quad 24082001 . h t m l .>$. Acesso em: 01 jul. 2003.

BRASIL. (2003c). Resolução/FNDE/CD/n. 015, de 16 de junho de 2003. Estabelecer critérios para o repasse de recursos financeiros, à conta do PNAE, previstos na Medida Provisória n. 2.178-36, de 24 de agosto de 2001. Disponível em <http://www.fnde.gov.br/programas/pnae/legislacao/res015 16062003.html >. Acesso em: 30 jun. 2003. 
BRASIL. (2003d). Resolução/FNDE/CD/n. 045 de 31 de outubro de 2003.Estabelecer critérios para o repasse de recursos financeiros, à conta do PNAE, previstos na Medida Provisória $\mathrm{n}^{\mathrm{o}}$ 2.178-36, de 24 de agosto de 2001, para o atendimento dos alunos da educação infantil e ensino fundamental matriculados em escolas de educação indígena. Disponível em

< http://www.fnde.gov.br/home/alimentacao_escolar/res045_31102003.pdf >. Acesso em: 26 fev. 2004.

BRASIL. (2004). Resolução/FNDE/CD/n. 38 de agosto de 2004.Estabelecer critérios para execução do PNAE. . Disponível em < http://www.fnde.gov.br/home/alimentacao_escolar/Resolucao_38_\%202004\%20\%20PNAE.doc >. Acesso em: 20 nov. 2004.

BUBENKO JR., J. et al. (1998). EKD user guide, Dpt of computer and systems sciences. Stockholm, Royal Institute of Technology.

BUBENKO JR., J. et al. (2001). HyperKnowledge. IST-2000-28401. Hipermedia and Pattern Based Knowledge. Management for Smart Organisations. D3: Appendix- B EKD User Guide. Stockholm, Sweden.

CALIL, R.; AGUIAR, J. (1999). Nutrição e administração nos serviços de alimentação escolar. São Paulo: Marco Markovitch.

COLMANETTI, A. L. V. (2003). O uso da tecnologia da informação para promover a gestão do conhecimento: identificação de requisitos para a proposição de um modelo. 106p. Dissertação (Mestrado) - Escola de Engenharia de São Carlos, Universidade de São Paulo, São Carlos. 2003.

DAMIANI, W. B. (2001). Gestão do Conhecimento: Um estudo comparativo Brasil x Estados Unidos. In: ENCONTRO ANUAL DA ASSOCIAÇÃO NACIONAL DOS PROGRAMAS DE PÓS-GRADUAÇÃO EM ADMINISTRAÇÃ̃O, 25., 2001, Campinas. CD-ROM.

DAVENPORT, T. H.; PRUSAK, L. (1998). Conhecimento empresarial: como as organizações gerenciam seu capital intelectual. Tradução de Lenke Peres.Rio de Janeiro: Campus.

DRUCKER, P. (1995). O normal em História é a turbulência. Entrevistado por Jorge Nascimento Rodrigues. Disponível em: $<$ http://www.janelanaweb.com/ manageme/drucker3.html $>$ Acesso em: 26 jan. 2000.

DRUCKER, P.. Desafios gerenciais para o século XXI. São Paulo: Pioneira, 1999

DUARTE, L.C. (2004). Direito Administrativo I. Capítulo 3 - Princípios da administração pública. Disponível em: <http://www.fada.adm.br/aprincipios.htm> Acesso em: 26 fev.

ENCYCLOPAEDIA Britannica do Brasil Publicações Ltda (2004). Administração Pública. Disponível em:http://www.originalis.hpg.ig.com.br/administracao.htm. Acesso em: 27 jun. 
EDVINSSON, L.; MALONE, M.S. (1998). Capital Intelectual. Tradução de Roberto Galman; revisai técnica Petros Katalifós. São Paulo: Makron Books.

FLEURY, A.; FLEURY, M. T. L. (2000) Estratégias Empresariais e Formação de Competências. São Paulo: Atlas.

FINGER, M.; BRAND, S. B. (2001). Conceito de "organização de aprendizagem" aplicado à transformação do setor público: contribuições conceituais ao desenvolvimento da teoria. In: EASTERBY-SMITH, M. Aprendizegem organizacional e organização de aprendizagem: desenvolvimento na teoria e na prática. Tradução de Silvia Maria Azevedo Roesch. São Paulo: Atlas. Cap. 8, p.165195.

GATTONI, R. L. C. (1999). Poemas, programas e pessoas: saudável digressão sobre o KM. Developers' Magazine. n. 39, p. 16-18, nov.

GEUS, A. de, O segredo da longevidade das empresas. 1999. Entrevistado por Jorge Nascimento Rodrigues.Disponível em: <http://www.janelanaweb.com/manageme/longevidade.html $>$. Acesso em 26 jan. 2000. $(26 / 01 / 00)$

GIL, A. C. (1991). Como elaborar projetos de pesquisa. São Paulo, Atlas.

GUTIERREZ, M. A. (1999). Developers’ Magazine, n. 39, p.7, nov.

INSTITUTO de políticas públicas Florestan Fernandes (2004). Gestão do conhecimento no setor público. Disponível em: <http://www.iff.org.br>. Acesso em 20 out.

JAMIL, G. L. (1999). TI e Conhecimento: Adequar para Evoluir. Developers 'Magazine, n.39, p.26.

KIRIKOVA, M. (2000) Explanatory capability of enterprise models. Data \& Knowledge Engineering, n.33, p.119-136.

KRUGLIANSKAS, I.; TERRA, J. C. C. (2003). Gestão do Conhecimento em pequenas e médias emnpresas. Rio de Janeiro: Campus.

LAPA, E. (2003). A gestão do conhecimento hoje no Brasil. Disponible em: <http://webinsider.uol.com.br/vernoticia.php?id=1942>. Acesso em 24 fev. 2004

MELLACI, F. et al. (1999) O Aprendizado Contínuo das Organizações. Developers'Magazine, n.39, p. 42

MINISTÉRIO DO PLANEJAMENTO, ORÇAMENTO E GESTÃO_ Secretaria de Gestão, (2004). Gestão Pública para um brasil de todos. Disponível em <http://www.enap.gov.br/programas desenvolvimento/ufam/modulo1.htm $>$.Acesso em 25 out. 
MIRSHAWKA, V., (1998). Conhecimento necessário para o trabalho. Qualimetria, n. 86 , Expo Mangement, p. 32-34, Buenos Aires, out.

MYERS, P. S.(1996). Knowledge Management and Organizational Design. Boston. Butterworth - Heinemann.

NONAKA, I.; TAKEUCHI, H. (1997). Criação de conhecimento na empresa. Tradução de Ana Beatriz Rodrigues, Priscilla Martins Celeste. Rio de Janeiro: Campus.

OETTERER, M. et. al. (1999). Avaliação do programa de alimentação escolar: projeto FNDCT (FINEP) - BID - $N^{o}$. 54.960.536.00. Piracicaba./Relatório de pesquisa ESALQ-LAN.

OLIVEIRA, R. (2004). Por uma administração pública profissional. Valor econômico. 07 de mar. 2003. Ano 04 - $\mathrm{N}^{\circ} 712$ - $1^{\circ}$ Caderno

PÁDUA, F. S. M. (2003). A importância de técnica de modelagem organizacional EKD no desenvolvimento de diagramas use case. 104p. Dissertação (Mestrado) Escola de Engenharia de São Carlos, Universidade de São Paulo, São Carlos. 2003.

PÁDUA, S. I. D. (2001). Investigação do processo de desenvolvimento de software a partir da modelagem organizacional, enfatizando regras do negócio. $144 \mathrm{p}$. Dissertação (Mestrado) - Escola de Engenharia de São Carlos, Universidade de São Paulo, São Carlos. 2001.

PESSOA, R. S. (2004). O alerta! A nova administração pública. Ética e Direito. Disponível em <http:// www.eticadireito.hpg.ig.com.br/alertanovaadministracaopublica-artigos.htm $>$ Acesso em: 25 jul. 2004.

PINHEIRO, M. (2004). O princípio da eficiência na administração pública e o cidadão. Disponível em: <http://www.acmag.com.br/HTML/eficiencia.htm>. Acesso em 26 fev.

PIPITONE, M.A.P. (1997). Programa de alimentação escolar: um estudo sobre descentralização, escola e educadores. 135p. Tese (Doutorado) - Universidade Estadual de Campinas, Campinas. 1997.

PIPITONE, M. A. P. (1998). Os arquivos brasileiros de nutrição e a trajetória de criação e consolidação da campanha nacional de alimentação escolar no Brasil. Cadernos de Nutrição. Sociedade Brasileira de Alimentação e Nutrição, São Paulo v. 15, p.33-50.

PORTUGAL, A. D. (2002). Mais do que simples promessas. Artigos Embrapa. Disponível <http://www.embrapa.br:8080/aplic/rumos.nsf/0/8d29291a88e2f00503256c71003b9 cd8? OpenDocument> Acesso em 4 abr. 2004. 
PREFEITURA DO MUNICÍPIO DE SÃO PAULO. Secretaria Municipal de Abastecimento (1996). Programas de alimentação do município de São Paulo. São Paulo.

PRUSAK, L. (1998). Buzzword de gestão cativa os homens do "software".Entrevistado por Jorge Nascimento Rodrigues.Executive Digest. mar.

PRUSAK, L.; DAVENPORT, T. H. (1999). O sucessor da Reengenharia. Disponível em: <http:// www.janelanaweb.com/livros/kmdigest.html >. Acesso em: 28 jan. 2000.

RODRIGUES, M.M. (2003). Publicação eletrônica [mensagem pessoal]. Mensagem recebida por aninhabr@terra.com.br em 18 mai. 2003.

RODRIGUEZ, M.; FERRANTE, A. (1995). Tecnologia de Informação e Mudanças Organizacionais. Rio de Janeiro. IBPI-PRESS/COPPE - UFRJ.

ROESCH, S. M. A. (1999). Projetos de estágio e de pesquisa em administração: guia para estágios trabalhos de conclusão, dissertações e estudos de caso. Colaboração Grace Vieira Becker, Maria Ivone de Mello. São Paulo: Atlas.

RUIZ, R. (1996). Informatização da merenda escolar. In: ENCONTRO ESTADUAL SOBRE ALIMENTAÇÃO ESCOLAR. Jundiaí, 1996. Anais. Campinas. FEA/UNICAMP.

SANTOS, et al. (2003). Gestão do conhecimento como modelo empresarial. Gestão do Conhecimento. SERPRO. Disponível em <http://www1.serpro.gov.br/publicacoes/gco_site/m_capitulo01.htm>. Acesso em 26 fev. 2004.

SANTOS, et al. (2004). Eficiência, eficácia e efetividade como indicadores de resultados na administração pública. Disponível em: http://www.milenio.com.br/siqueira/Cp237.htm. Acesso em 25 fev. 2004.

SAXENA, K. B. C. (2004). Reengenharia da administração pública nos países em desenvolvimento.

em: http://reforma.pjf.mg.gov.br/arq conceito/reengenharia administracao. htm. Acesso em 26 fev. 2004.

SENGE, Peter M. A quinta disciplina. São Paulo: Editora Best Seller, 1990.

SERAFIM FILHO, P. (1999). A Gestão do conhecimento e a motivação nas Organizações. Revista Decidir. janeiro/1999. Disponível em: <http://www.perspectivas.com.br/leitura/g8.htm>. Acesso em: 25 jan.2000.

SILVA, C. M. (2003). A gestão do conhecimento: estudo de caso em uma empresa fabricante de móveis rústicos. 117p. Dissertação (Mestrado) - Escola de Engenharia de São Carlos, Universidade de São Paulo, São Carlos. 2003. 
STURION, G.L. (2002). Programa de alimentação escolar:avaliação do desempenho em dez municípios brasileiros. 269p. Tese (Doutorado) - Universidade Estadual de Campinas, Campinas.2002.

SVEIBY, K. E. (1998). A nova riqueza das organizações: gerenciando e avaliando patrimônios de conhecimento. Tradução de Luiz Euclydes Trindade Frazão Filho. Rio de Janeiro: Campus.

TAKASHINA, N. T. (1999). Era da Gestão da Sabedoria: Modismo ou tendência da Qualidade para o próximo milênio? . Disponível em: <http://www.kmpress.com.br/dez9903.htm>. Acesso em: 26 jan. 2000.

TERRA, J. C. C. (2003a). Gestão do conhecimento para o Brasil. Disponível em <http://www.terraforum.com.br>. Acesso em 26 nov. 2003.

TERRA, J. C. C. (2003b). Definindo gestão do conhecimento. Disponível em <http://www.terraforum.com.br>. Acesso em 16 ago. 2003.

TERRA, J. C. C..; BARBOSA D. K. (2004). Gestão de serviços e gestão do conhecimento. Disponível em <http://www.terraforum.com.br>. Acesso em 30 nov 2004.

TEIXEIRA FILHO, J. Perspectivas em Gestão do Conhecimento. Developers' Magazine. n. 30, p.30-31, nov. 1999. Insight Informal [048-07/01/2002]. Disponível em http://www.informal.com.br/insight/insight48.htm Acesso em 4 abr. 2004.

TEIXEIRA FILHO, J.; OLIVEIRA, G. N. (2001). Gestão do conhecimento no espaço público. Insight Informal. n. 047, dez. 2001. Disponível em: http://www.informal.com.br/insight/insight4/.htm. Acesso em: 5 ago. 2003.

TOHÁ, C. ; SOLARI, R. (2004). Revista do Serviço Público/Escola Nacional de Administração Pública - v.1, n.1(1937) - Ano 48, n.3 (Set-Dez/1997). Disponível em <http://www.enap.gov.br/programas_desenvolvimento/ufam/modulo1.htm>.Acesso em 25 out.

TOFFLER, A. (2000). A Europa continua a viver no passado.Entrevistado por Jorge Nascimento Rodrigues. Disponível em: <http://www.janelanaweb.com/manageme/toffler.html>. Acesso em: 7 fev. 2000.

TREVISAN, A. M. et al. (2003). O combate à corrupção nas prefeituras do Brasil. Cotia, SP.: Ateliê Editorial.

UNIVERSIDADE DE SÃO PAULO. Escola de Engenharia de São Carlos. Serviço de Biblioteca (2002). Diretrizes para elaboração de dissertações e teses na EESC_USP. 3.ed.. São Carlos. Disponível em: <http://www.eesc.sc.usp.br/biblioteca.> Acesso em: 29 abr. 2003.

WELS, A.M.C. (2004) Assessorias de Comunicação Social na esfera pública. Disponível em: <http://www.pucrs.br/famecos/geacor/texto11-03.html>Acesso em: 26 fev. 


\section{APÊNDICE A - PROGRAMA DE ALIMENTAÇÃO ESCOLAR}

\section{Considerações iniciais}

O presente capítulo está voltado à apresentação do Programa de Alimentação Escolar em níveis internacional e nacional.

Em nível internacional apresenta uma síntese do que se entende por programas de alimentação escolar e quais as maiores preocupações quanto aos programas que ficaram transparecidas através de análise realizada em publicações sobre o tema.

Em nível nacional, considera seu histórico procurando abranger discussões iniciais sobre a necessidade de alimentação para escolares ocorridas no ano de 1943 até os mais recentes critérios para a operacionalização do que hoje é conhecido como Programa Nacional de Alimentação Escolar (PNAE).

Apresenta também, aspectos gerais necessários à administração do Programa, propostos por estudiosos do tema, dos quais podemos citar: atividades que devem ser consideradas e se fazem necessárias à sua operacionalização de forma completa.

\section{O Programa de Alimentação Escolar em outros países}

Segundo Pipitone (1998), na década de 40 houve uma atenção especial quanto à alimentação infantil por iniciativa da Organização das Nações Unidas (ONU) que esboçou um programa internacional de assistência alimentar, culminando com os seguintes acontecimentos:

- em 1943 o Instituto Internacional de Proteção à Infância se reuniu em Montevidéu e recomendou os inquéritos alimentares, para se avaliar o estado nutricional das crianças em idade escolar; 
- em 1946, foi criado o Fundo Internacional de Socorro à Infância (FISI), pela Assembléia das Nações Unidas e, em 1947, a Organização Mundial de Saúde (OMS) e a Food and Agriculture Organization (FAO), passam a fixar valores mínimos de nutrientes destinados à alimentação da criança;

- em 1948, em Montevidéu, a $1^{\text {a }}$ Conferência Latino-Americana de Nutrição, patrocinada pela FAO, recomendou a distribuição de refeições aos escolares como medida de combate à desnutrição infantil;

- em 1950, a $2^{a}$ Conferência Latino-Americana de Nutrição, realizada no Brasil, insistia na distribuição de refeições aos escolares.

De acordo com Sturion (2002) a prática de programas de alimentação surgiu durante a realização, seis anos após a $2^{\mathrm{a}}$ Guerra Mundial, da $14^{\mathrm{a}}$ Conferência sobre Educação Pública, organizada pela United Nations Educational, Scientific and Cultural Organization (UNESCO) e, durante o Internacional Bureau of Education em Genebra em 1951. Atualmente está presente em diversos países apresentando características distintas.

Os Estados Unidos, a França, o Japão e o Canadá encaram a alimentação escolar como um dever do Estado estando incorporada às atividades pedagógicas com enfoque fisiológico, ou seja, sanar a fome que o aluno sente durante o período de aula. (STURION, 2002).

Nos Estados Unidos existe uma preocupação em se evitarem doenças crônicas degenerativas e a obesidade através do monitoramento de diferentes tipos de gorduras e sódio presentes na composição da alimentação oferecida ao escolar. Em países em desenvolvimento o programa passa a ter um caráter assistencialista, dirigido apenas ao combate à fome.

Na América Latina, ainda segundo Sturion (2002), apresentam-se dois grupos de países de acordo com as características adotadas pelos programas de alimentação escolar: o primeiro grupo inclui o Brasil, a Argentina e o Chile com políticas e programas financiados com recursos públicos nacionais, com tradição, identidade própria e políticas de alimentação com objetivos e metas estabelecidos. O segundo 
grupo é composto pela Guatemala, Nicarágua, Peru e República Dominicana e caracteriza-se pela falta de tradição institucional na área, programas com vida curta e dependência de ajuda de organismos internacionais.

Segundo pesquisa realizada em publicações sobre o Programa de Alimentação Escolar, Pipitone (1997), alega que internacionalmente a preocupação maior quanto ao Programa está voltada para sua melhoria, buscando ajustá-lo cada vez mais à população beneficiada, maximizando os benefícios esperados e minimizando os recursos investidos.

Um dado bastante significativo e também resultante da análise realizada, diz respeito aos temas abordados nas publicações (quadro 01). Estes, confirmam o pequeno interesse na Administração do Programa de Alimentação Escolar pois representam, conforme quadro 01 , menos do que $9 \%$ (nove por cento) do montante analisado.

\begin{tabular}{|l|c|}
\hline \multicolumn{1}{|c|}{ Temas dos artigos } & Quantidade de artigos \\
\hline 1. merenda escolar X estado nutricional do escolar & 36 \\
\hline \multicolumn{1}{|c|}{ 1.1. avaliação do consumo específico de leite e cereais } & 19 \\
\hline $\begin{array}{l}\text { 2. utilização de alimentos enriquecidos e/ou modificados na merenda } \\
\text { escolar }\end{array}$ & 12 \\
\hline $\begin{array}{l}\text { 3. merenda escolar e educação nutricional } \\
\text { 4. análise econômica do programa de merenda escolar (custos e } \\
\text { benefícios) }\end{array}$ & 11 \\
\hline 5. administração do programa de merenda escolar & 08 \\
\hline 6. controle de qualidade de alimentos usados na merenda escolar & Total \\
\hline
\end{tabular}

Quadro 01: Artigos relacionados ao tema da alimentação escolar encontrados em busca bibliográfica internacional - 1995

Fonte: PIPITONE (1997). 


\section{O Programa Nacional de Alimentação Escolar (PNAE)}

O Programa Nacional de Alimentação Escolar (PNAE), mais conhecido como Merenda Escolar, vem cumprindo um importante papel no contexto social do País ao garantir recursos financeiros para suprir parcialmente as necessidades nutricionais dos alunos, durante o período de permanência na escola.

Dentre os programas existentes a nível Federal, o Programa Nacional de Alimentação escolar (PNAE) é o programa de maior longevidade, completando 48 (quarenta e oito) anos de existência em 2003.

O Programa Nacional de Alimentação Escolar, envolve 5.560 municípios brasileiros atendidos, totalizando 37,8 milhões de alunos atendidos com investimento de $\mathrm{R} \$ 1.025,0$ milhões de reais.

\begin{tabular}{|c|c|c|}
\hline Ano & $\begin{array}{c}\text { Recursos financeiros } \\
\text { (em milhões de R\$) }\end{array}$ & $\begin{array}{c}\text { Alunos atendidos } \\
\text { (em milhão) }\end{array}$ \\
\hline 1995 & 590,1 & 33,2 \\
\hline 1996 & 454,1 & 30,5 \\
\hline 1997 & 672,8 & 35,1 \\
\hline 1998 & 785,3 & 35,3 \\
\hline 1999 & 871,7 & 36,9 \\
\hline 2000 & 901,7 & 37,1 \\
\hline 2001 & 920,2 & 37,1 \\
\hline 2002 & 848,6 & 36,9 \\
\hline 2003 & 954,2 & 37,3 \\
\hline 2004 & $1.025,0$ & 37,8 \\
\hline
\end{tabular}

Tabela 01, Capítulo 5 - Dados estatísticos sobre recursos aplicados e clientela atendida pelo PNAE. Fonte: http://www.fnde.gov.br

Os recursos repassados são encaminhados exclusivamente para a aquisição de gêneros alimentícios e, por não serem suficientes, fica sob a responsabilidade das Entidades Executoras a complementação necessária, como também, todos os outros custos envolvidos na operacionalização do Programa. 
Gerenciado pelo Fundo Nacional de Desenvolvimento da Educação (FNDE), autarquia vinculada ao Ministério da Educação (MEC), o programa atualmente é gerido por diferentes Entidades Executoras através de diferentes modalidades, sendo estas, previstas pela legislação existente.

Entende-se por Entidade Executora (EE), as entidades responsáveis pelo recebimento e pela utilização dos recursos financeiros repassados pelo Programa Nacional de Alimentação Escolar, obedecendo às regras definidas em lei, sendo elas:

- Secretarias de Educação dos Estados e do Distrito Federal, responsáveis pelo atendimento das creches e escolas públicas da rede estadual e do Distrito Federal, respectivamente;

- Prefeituras Municipais responsáveis pelo atendimento das creches e escolas públicas municipais, pelas escolas mantidas por entidades beneficentes de assistência social e, também, pelas escolas da rede estadual, quando isso lhes for delegado pelas Secretarias de Educação dos Estados;

- Creches e Escolas Federais beneficiadas com os recursos recebidos diretamente do FNDE, ou com recursos ou gêneros alimentícios recebidos por intermédio das Prefeituras Municipais, dos Municípios onde estão localizadas, quando isso for de interesse dessas escolas. (BRASIL, 2003c).

As modalidades existentes e adotadas na gestão do Programa Nacional de Alimentação Escolar, segundo Sturion (2002), são:

- Estadualização na qual a Secretaria de Estado da Educação é a Entidade Executora encaminhando os gêneros alimentícios para a rede de ensino estadual ou toda a rede de ensino do município;

- Municipalização onde a Prefeitura Municipal é a Entidade Executora, assumindo a gestão do Programa junto a rede de ensino municipal ou todas as unidades de ensino da rede seja municipal ou estadual;

- Autonomização da Escola ou Escolarização envolve a descentralização e a desconcentração das atividades decisórias e gerenciais. Os recursos são recebidos pela Prefeitura Municipal e repassados para as unidades escolares que passam a ser as Entidades Executoras do Programa; 
- Terceirização compreende estabelecer, por meio de contrato, a responsabilidade por toda a execução do Programa às empresas especializadas, ficando a administração municipal responsável pela fiscalização e controle desta execução. Neste caso, Brasil (2003c), estabelece que os recursos repassados pela União só poderão ser aplicados na aquisição dos gêneros alimentícios sendo os demais custos de operacionalização responsabilidade da administração municipal.

Como um dos órgãos fiscalizadores do Programa Nacional de Alimentação Escolar e, um dos requisitos para a continuidade dos repasses, a Entidade Executora deve constituir o Conselho de Alimentação Escolar (CAE), com representantes da comunidade a que esta pertence.

\subsection{Objetivo do programa}

O Programa Nacional de Alimentação Escolar após seus 48 anos de existência, passando por reformulações quanto ao seu objetivo principal relatadas em Sturion (2002), apresenta atualmente, segundo a Resolução/FNDE/CD/n. 015 de 16 de junho de 2003. Estabelecer critérios para o repasse de recursos financeiros, à conta do PNAE, previstos na Medida Provisória n. 2.178-36, de 24 de agosto de 2001. (BRASIL, 2003c), o seguinte objetivo: "suprir parcialmente as necessidades nutricionais dos alunos, com vistas a garantir a implantação da política de Segurança Alimentar e contribuir para a formação de bons hábitos alimentares".

Já a Resolução/FNDE/CD/n. 045 de 31 de outubro de 2003. Estabelecer critérios para o repasse de recursos financeiros, à conta do PNAE, previstos na Medida Provisória n. 2.178-36, de 24 de agosto de 2001., para o atendimento de alunos da educação infantil e do ensino fundamental matriculados em escolas de educação indígena. (BRASIL, 2003d), apresenta como objetivo do programa "suprir parcialmente as necessidades nutricionais dos alunos, com vistas a garantir a implantação da política de Segurança Alimentar e Nutricional e contribuir para a valorização e fortalecimento da cultura alimentar indígena". 
Hoje, a Resolução/FNDE/CD/n. 038 de 23 de agosto de 2004. Estabelecer critérios para a execução do PNAE. Em seu Art. $2^{\circ}$ apresenta como onjetivo atender às necessidades nutricionais dos alunos, durante sua permanência em sala de aula, contribuindo para o crescimento e desenvolvimento dos alunos; a aprendizagem e o rendimento escolar; bem como a formação de hábitos alimentares saudáveis. (BRASIL, 2004)

\subsection{Histórico do programa}

No Brasil, segundo Pipitone (1998), as primeiras iniciativas de administração de assistência alimentar aos escolares foram mantidas pelos jesuítas nos tempos coloniais.

Na década de 30, segundo Calil e Aguiar (1999), as escolas deram início ao atendimento dos alunos com alimentação e objetivos assistenciais, através da arrecadação junto aos próprios estudantes, às empresas e à comunidade dos gêneros necessários à alimentação. Em algumas unidades o atendimento era feito aos mais carentes, em outras a todos os que iam à escola.

A Prefeitura do Município de São Paulo, SP (1996), registra as primeiras iniciativas no sentido da alimentação do escolar através do fornecimento de um lanche composto por um copo de leite às crianças de 3 a 12 anos atendidas pelos Parques Infantis no ano de 1935.

Em 1936 surgiram no Distrito Federal os primeiros ensaios de assistência alimentar servida aos escolares.

Em 1939 o Ministério da Educação e Saúde passa a regulamentar a alimentação de escolares em estabelecimentos de ensino secundários e comerciais em todo o Brasil.

O Programa Nacional de Alimentação Escolar tem sua origem no início da década de 40, quando o Instituto de Nutrição, à época, já defendia uma proposta de se oferecer alimentação ao escolar. Entretanto, não foi possível concretizá-la, por não haver interesse político e, por conseqüência, indisponibilidade de recursos financeiros. 
Na década de 50, foi elaborado um abrangente Plano Nacional de Alimentação e Nutrição, denominado: A Conjuntura Alimentar e o Problema da Nutrição no Brasil, o qual se constituía em uma ampla proposta de solução do problema alimentar. É nele que, pela primeira vez, se concebe e estrutura um programa de alimentação escolar, em âmbito nacional e sob responsabilidade pública.

Desse Plano, apenas o Programa da Alimentação Escolar sobreviveu, contando com o financiamento do Fundo Internacional de Socorro à Infância (FISI), atualmente United Nations International Children Emergency Fund (UNICEF), que permitiu a distribuição do excedente de leite em pó e do excedente da super-safra americana em 1954, com o final da guerra da Coréia. O repasse feito ao Brasil atendeu inicialmente, estudantes carentes de alguns Estados (Ceará, Paraíba, Piauí e Rio Grande do Norte).

A opção pela clientela escolar recaiu, basicamente, por ser uma população carente em termos nutricionais e por oferecer a vantagem da aglomeração, permitindo, assim, rapidez e economia de escala na distribuição, além de possuir legitimação técnica, pela conexão entre alimentação e aprendizagem.

Em 31 de março de 1955, é instituída a Campanha de Merenda Escolar (CME), subordinada ao Ministério da Educação, ocasião em que foram celebrados convênios diretamente com o FISI e outros organismos internacionais. Em 1956, passou a denominar-se Campanha Nacional de Merenda Escolar (CNME), com a intenção de promover o atendimento em âmbito nacional.

Durante a década de 1960, o nome da CNME foi alterado para Campanha Nacional de Alimentação Escolar (CNAE) e surgiu um elenco de programas de ajuda americana, dentre os quais se destacavam o de Alimentos para a Paz, cujo financiamento era de responsabilidade da United State Agency for International Development (USAID) voltado para o atendimento às populações carentes e alimentação de crianças em idade escolar e o Programa Mundial de Alimentos da Food and Agriculture Organization (FAO). 
Até o final da década de 60 a United State Agency for International Development (USAID), é a única fornecedora de leite em pó para a Campanha ficando o governo brasileiro com a contrapartida de $20 \%$ dos gêneros distribuídos. (STURION, 2002).

Na década de 70, a Campanha passa a adquirir grande quantidade de alimentos no mercado interno, centralizando as decisões a nível federal e reduzindo a participação dos setores regionais, incentivando o consumo de produtos formulados industrialmente.

A partir de 1976, embora financiado pelo Ministério da Educação e gerenciado pela Campanha Nacional de Alimentação Escolar, era parte do II Programa Nacional de Alimentação e Nutrição (PRONAN) e, somente em 1979, passou a denominar-se Programa Nacional de Alimentação Escolar (PNAE), como é hoje.

Com a promulgação da nova Constituição Federal, em 1988, ficou assegurado o direito à alimentação escolar a todos os alunos do ensino fundamental, por meio de programa suplementar de alimentação escolar, a ser oferecido pelos Entes Públicos Federal, Estaduais e Municipais.

Desde sua criação até 1993, a execução do Programa se dá de forma centralizada, ou seja, o órgão gerenciador do Programa realiza o planejamento dos cardápios, adquire os gêneros por processo licitatório, contrata laboratórios especializados para efetuar o controle de qualidade, e ainda se responsabiliza pela distribuição desses alimentos em todo o território nacional.

Durante o período de 1986 a 1989, foram feitas experiências de descentralização junto aos municípios, cuja população era superior a 50.000 habitantes, mediante assinatura de Termo de Adesão Voluntária e comprovação de condições técnicoadministrativas para implementação do Programa.

Em 1994, , foi instituída a descentralização dos recursos para execução do Programa, mediante celebração de convênios com os municípios já engajados e com o envolvimento das secretarias de educação dos estados e do Distrito Federal, às quais 
delegou-se competência para atendimento aos alunos de suas redes e das redes municipais das prefeituras que não haviam aderido à descentralização.

Nesse período o número de municípios que aderiram à descentralização evoluiu de 1.532 (hum mil, quinhentos e trinta e dois) em 1994 para 4.314 (quatro mil, trezentos e quatorze) em 1998, representando mais de 70\% dos municípios brasileiros.

Em 1997 as competências da Fundação de Assistência ao Estudante (FAE), criada em 1983, como órgão responsável pela execução do Programa Nacional de Alimentação Escolar, até então, gerido de maneira centralizada e concentrada no âmbito federal, passam a ser desenvolvidas pelo Fundo Nacional de Desenvolvimento da Educação (FNDE).

A consolidação da descentralização, já sob o gerenciamento do FNDE, se deu em 14 de dezembro de 1998, onde, além do repasse direto a todos os municípios e secretarias de educação, a transferência passou a ser feita automaticamente, dispensando-se a celebração de convênios ou quaisquer outros instrumentos similares, permitindo, assim, maior agilidade ao processo.

A Medida Provisória n. 2.178 de 24 de agosto de 2001. Dispõe sobre o repasse de recursos financeiros do Programa Nacional de Alimentação Escolar, institui o Programa Dinheiro Direto na Escola, altera a Lei n. 9.533, de 10 de dezembro de 1997, que dispõe sobre o programa de renda mínima, institui programas de apoio da União às ações dos Estados e Municípios, voltadas para o atendimento educacional, e dá outras providências. (BRASIL, 2003b), que se encontra hoje em sua trigésima sexta edição, propicia grandes avanços ao PNAE. Dentre os quais se destacam a obrigatoriedade de que $70 \%$ dos recursos transferidos pelo Governo Federal sejam aplicados exclusivamente em produtos básicos (Anexo A, p.119), o respeito aos hábitos alimentares regionais e à vocação agrícola do município, fomentando também o desenvolvimento da economia local.

Com esse novo modelo de gestão do PNAE, a transferência dos recursos financeiros, tem ocorrido de forma sistemática, permitindo assim, o planejamento 
prévio das aquisições dos gêneros alimentícios, de modo a assegurar a oferta da alimentação escolar durante todo o ano letivo. Além disso, ficou estabelecido que o saldo dos recursos financeiros existente ao final de cada exercício, deve ser reprogramado para o exercício seguinte e ser aplicado, exclusivamente, na aquisição de gêneros alimentícios

Outra grande conquista foi a instituição, em cada município brasileiro, por instrumento legal próprio, do Conselho de Alimentação Escolar (CAE), como órgão deliberativo, fiscalizador e de assessoramento para execução do Programa.

\subsection{Beneficiários do programa}

Os beneficiados pelo Programa, atualmente, são os alunos de escolas públicas e de escolas mantidas por entidades beneficentes de assistência social que freqüentam as Creches, a Educação Pré-Escolar e o Ensino Fundamental, devidamente registrados no censo escolar, realizado pelo Ministério da Educação, no ano anterior ao do atendimento. (BRASIL, 2003c).

Em outubro de 2003, a Resolução/FNDE/CD/n. 045 de 31 de outubro de 2003. Estabelecer critérios para o repasse de recursos financeiros, à conta do PNAE, previstos na Medida Provisória n. 2.178-36, de 24 de agosto de 2001., para o atendimento de alunos da educação infantil e do ensino fundamental matriculados em escolas de educação indígena. (BRASIL, 2003d), inclui como beneficiários alunos matriculados na educação infantil e no ensino fundamental das escolas de educação indígena da rede pública de ensino dos estados e dos municípios ou em estabelecimentos mantidos pela União, utilizando os critérios do censo como nos demais atendimentos.

As entidades beneficentes de assistência social, além de serem cadastradas no censo, devem ser registradas no Conselho Nacional de Assistência Social para se beneficiarem dos repasses.

O censo escolar faz parte do Sistema Integrado de Informações Educacionais e é desenvolvido, anualmente, pelo Instituto Nacional de Estudos e Pesquisas Educacionais 
(INEP), por intermédio das Secretarias Estaduais de Educação e com recursos do Fundo Nacional de Desenvolvimento da Educação (FNDE).

O Conselho Nacional de Assistência Social (CNAS) é um órgão ligado ao Ministério da Previdência e Assistência Social. As entidades sem fins lucrativos precisam solicitar ao referido Conselho um Registro e o Certificado de Fins Filantrópicos, que as isentam do pagamento, ao Instituto Nacional do Seguro Social (INSS), da cota patronal da contribuição previdenciária de seus empregados. (BRASIL, 2001).

\subsection{Recursos financeiros}

O Governo Federal, por intermédio do Fundo Nacional de Desenvolvimento da Educação (FNDE), repassa os recursos financeiros aos Estados, Municípios e Distrito Federal, para compra, exclusivamente, dos gêneros alimentícios utilizados na alimentação escolar. Essa transferência é feita automaticamente, sem a necessidade de nenhum convênio, acordo ou contrato.

O FNDE deposita os recursos em contas bancárias específicas do PNAE, uma para o atendimento dos alunos da pré-escola e ensino fundamental, uma segunda para o atendimento dos alunos de creches e a terceira conta, quando houver, para atendimento de alunos indígenas, aberta pelo próprio Fundo, em agências do Banco do Brasil, da Caixa Econômica Federal ou dos bancos credenciados. Após o repasse as Entidades Executoras tornam-se responsáveis pelo recebimento e pela utilização dos recursos do Programa.

Os recursos são transferidos em 10 parcelas periódicas, durante os meses de fevereiro a novembro, correspondentes cada uma a 20 dias, para suprir os dias de efetivo trabalho escolar definidos pela Lei n. 9.394 de 20 de dezembro de 1996 que estabelece as diretrizes e bases da educação nacional. (BRASIL, 1996). 
As aquisições de gêneros para a Alimentação Escolar devem obedecer a todos os critérios estabelecidos na Lei $\mathrm{n}^{\circ}$ 8.666, de 21 de junho de 1993 que regulamenta o art. 37, inciso XXI, da Constituição Federal, institui normas para licitações e contratos da Administração Pública e dá outras providências. (BOSELLI LICITAÇÕES S/C Limitada, 1999).

A fiscalização dos recursos financeiros é de competência do Tribunal de Contas da União, do FNDE e do CAE.

Segundo Brasil (2003c e d), o cálculo dos valores destinados a cada Entidade Executora (EE), para atender a clientela, tem por base a form.(1) a seguir:

$$
\mathrm{VT}=\mathrm{A} \times \mathrm{D} \times \mathbf{C}
$$

sendo: $\mathrm{VT}=$ valor a ser transferido;
A = número de alunos;
$\mathrm{D}$ = número de dias de atendimento;
C = valor per capita da refeição.

- O número de alunos corresponde ao oficialmente informado pelo Censo Escolar do ano anterior ao do atendimento;

- O número de dias de atendimento corresponde a 200 (duzentos) dias/ano para a Educação Pré-escolar e o Ensino Fundamental e, 250 (duzentos e cinquienta) dias/ano para as creches e escolas indígenas, isto, a partir do ano de 2004;

- O valor per capita repassado pelo Fundo Nacional de Desenvolvimento da Educação (FNDE) é de R $\$ 0,15$ (treze centavos de real) para alunos da Educação Pré-escolar e Ensino Fundamental; de R \$ 0,18 (dezoito centavos de real) para alunos de creches e $\mathrm{R} \$ 0,34$ (trinta e quatro centavos de real) por dia de efetivo trabalho escolar. (BRASIL, 2003c e d). 
Outro recurso é destinado ao Programa de Alimentação escolar, apenas para alunos da rede estadual, sendo sua fonte o Governo do Estado de São Paulo através da Secretaria Estadual de Educação. O valor do repasse é de $\mathrm{R} \$ 0,06$ (seis centavos de real) por dia letivo, por aluno, realizado em parcelas trimestrais durante o ano.

\subsection{O conselho de alimentação escolar (CAE)}

Esse Colegiado Deliberativo é composto por 7 (sete) membros titulares, sendo: dois representantes de pais de alunos, dois dos professores, um da comunidade (sociedade civil), um do poder executivo e um do poder legislativo, cada membro com mandato de dois anos, indicados pelas respectivas categorias que representam. Deve ter um Presidente e Vice-Presidente, eleitos entre os titulares, em assembléia, convocada para tal finalidade.

O Conselho tem papel determinante no Programa de Alimentação Escolar, integrando os membros em todas as etapas de sua execução: fiscalizando a aplicação dos recursos desde a aquisição até a distribuição da alimentação aos alunos, passando pelo acompanhamento de testes de aceitabilidade; controle de qualidade dos produtos; condições de armazenagem; e, finalmente, o recebimento, a análise e remessa, ao FNDE, da prestação de contas dos recursos, que é feita anualmente pela Entidade Executora, condição indispensável para garantir o repasse no ano subseqüente. (BRASIL, 2003c).

Compete ao CAE divulgar o recebimento dos recursos pela Entidade Executora, junto à comunidade; comunicar ao FNDE qualquer irregularidade verificada na utilização dos recursos e ainda, elaborar relatórios sempre que solicitado pela Autarquia.

\section{Administração do Programa de Alimentação Escolar em nível municipal}

A administração do programa de alimentação a nível municipal é uma realidade no país e necessidade de qualquer município enquanto Entidade Executora que queira 
receber os repasses provenientes do governo Federal. Em sua grande maioria, encontrase vinculada com a Secretaria ou Diretoria de Educação.

Infelizmente, como já apresentado anteriormente, o tema Administração do programa de alimentação escolar, não é muito explorado entre pesquisadores até os tempos atuais apesar de Calil e Aguiar (1999, p.16) afirmarem que:

\footnotetext{
É fundamental a obrigatoriedade da profissionalização desta prestação de serviço, que viabilize, através da adoção de normas e procedimentos adequados, a melhor aplicação de dinheiro público, com conseqüente diminuição das perdas e do desperdício que pode ser notado em muitas cidades do Estado.
}

Como objetivos do serviço de alimentação escolar de um modo geral, os mesmos autores apresentam:

- Preparar e distribuir alimentação destinada a escolares;

- Promover programas de educação alimentar envolvendo toda a comunidade escolar;

- Integrar equipe multidisciplinar com atenção ao aluno;

- Contribuir com estudos no campo da nutrição;

- Planejar, normatizar, executar, avaliar e corrigir as etapas necessárias para o desenvolvimento dos objetivos citados. (CALIL e AGUIAR, 1999, p.13).

Um dos processos necessários à administração do Programa de maneira geral e, um dos primeiros, é o planejamento de cardápios que deve obedecer a algumas determinações:

1. ser elaborado por nutricionista habilitado, com a participação do Conselho de Alimentação Escolar (CAE);

2. suprir, no mínimo, por refeição, $15 \%$ (quinze por cento) das necessidades nutricionais diárias dos alunos beneficiados;

3. utilizar, no mínimo, $70 \%$ (setenta por cento) dos recursos financeiros na compra de produtos básicos;

4. respeitar os hábitos alimentares de cada localidade e sua vocação agrícola. (BRASIL, 2003c). 
Ainda outras necessidades existem quanto à operacionalização do planejamento de cardápios que são:

1. conhecer qual o recurso financeiro previsto, ou seja, a dotação orçamentária, para o gasto com gêneros alimentícios que o município disponibiliza no ano;

2. considerar a demanda de Unidades Escolares e alunos beneficiados, por tipo de ensino;

3. considerar a mão-de-obra disponível para viabilização do cardápio;

4. considerar a infra-estrutura disponível para o preparo das refeições;

5. definir e adequar per capita dos gêneros alimentícios a serem utilizados de acordo com a realidade da clientela a ser atendida.

Após os cardápios estarem definidos, são necessárias as aquisições de gêneros que devem obedecer a uma série de requisitos legais, tanto com relação à qualidade como às formas de compra, formas de pagamento, entrega de mercadorias e outros fatores.

A parte que geralmente fica sob a responsabilidade do setor de alimentação municipal é solicitar as quantidades a serem adquiridas através de requisição de material que deverá conter a especificação do produto incluindo normas técnicas de padrão de saúde, características de embalagem, validade e formas de entrega.

As aquisições para a alimentação escolar têm características bastante peculiares, pois como toda aquisição realizada pelo setor público, deve respeitar a Lei $n^{\circ} 8.666$, de 21 de junho de 1993 que regulamenta o art. 37, inciso XXI, da Constituição Federal, institui normas para licitações e contratos da Administração Pública e dá outras providências. (BOSELLI LICITAÇÕES S/C Limitada, 1999). Na grande maioria das vezes os fornecedores são intermediários entre o fabricante e a prefeitura, pois os primeiros não se submetem às exigências dos editais e, nem às formas de pagamento previstas pelos mesmos.

Desta forma o setor de alimentação escolar deve cercar-se de exigências a fim de garantir a qualidade do produto que será adquirido. Como algumas das exigências feitas 
aos concorrentes e possíveis fornecedores, podem-se citar: apresentação de certificado ou declaração de órgão de vigilância sanitária de registro do produto e fiscalização das instalações e dos veículos que serão utilizados para o transporte no momento da entrega; entrega de amostras no momento do certame licitatório para futuras comparações e análise laboratoriais e aplicação de teste de aceitabilidade dos produtos a serem adquiridos.

Após adquiridos os gêneros alimentícios, o setor de alimentação escolar passará a operacionalização do processo de armazenamento e distribuição dos mesmos, sendo necessário normatizar procedimentos e documentos a serem utilizados. Como este serviço está submetido a auditorias e fiscalizações constantes de vários órgãos estaduais e federais, a conduta correta é a de registrar todos os gêneros alimentícios que entram e qual o destino que têm, com assinaturas e datas que atestem o recebimento dos mesmos.

Na alimentação escolar, costuma-se dividir os gêneros em estocáveis (arroz, feijão, farinha, fubá, lataria, etc) e em perecíveis (hortifrutigranjeiros, carnes, leite e derivados, pães, etc) a quantidade e periodicidade de abastecimento, na maioria das vezes, é definida a partir desta divisão. (CALIL e AGUIAR, 1999).

Outros aspectos também devem ser considerados para a quantidade de entrega de gêneros nas Unidades Escolares: possíveis sobras estocadas nas mesmas; dias úteis para atendimento; festividades e reuniões, sendo necessário portanto um canal de comunicação ativo e eficiente entre as Unidades e o Setor de Alimentação Escolar.

Este canal de comunicação deve fornecer ao setor, informações das Unidades que possam ser utilizadas em atividades de controle e fiscalização das mesmas no preparo e distribuição das refeições aos alunos beneficiados a fim de se evitarem os desperdícios. 


\section{Considerações finais}

O presente apêndice faz-se necessário para fornecer ao leitor referencial de apoio aos aspectos gerais do Programa Nacional de Alimentação Escolar (PNAE), principalmente no que se refere às Leis que regem de forma global qualquer iniciativa com relação à alimentação de escolares e sua forma de execução. 